\title{
INFLUÊNCIA DA APLICAÇÃO DE CICLAGEM COM CARGAS DINÂMICAS NA MICROINFILTRAÇÃO MARGINAL EM COROAS METALOCERÂMICAS CIMENTADAS COM TRÊS TIPOS DE CIMENTOS
}

PAULO HENRIQUE ORLATO ROSSETTI

Dissertação apresentada à Faculdade de Odontologia de Bauru, da Universidade de São Paulo, como parte dos requisitos para obtenção do título de Mestre em Reabilitação Oral.

(Edição Revisada) 


\title{
INFLUÊNCIA DA APLICAÇÃO DE CICLAGEM COM CARGAS \\ DINÂMICAS NA MICROINFILTRAÇÃO MARGINAL EM COROAS METALOCERÂMICAS CIMENTADAS COM TRÊS TIPOS DE CIMENTOS
}

\section{PAULO HENRIQUE ORLATO ROSSETTI}

\author{
Dissertação apresentada à \\ Faculdade de Odontologia de \\ Bauru, da Universidade de São \\ Paulo, como parte dos requisitos \\ para obtenção do título de Mestre \\ em Reabilitação Oral. \\ (Edição Revisada)
}

Orientador: Prof. Dr. Luiz Fernando Pegoraro 


\begin{tabular}{|c|}
\hline Rossetti, Paulo Henrique Orlato \\
R735i \\
Influência da aplicação de ciclagem com cargas \\
dinâmica na microinfiltração marginal em coroas \\
totais metálicas cimentadas com três tipos de cimentos \\
/ Paulo Henrique Orlato Rossetti. - Bauru, 2003. \\
145p. : il. ; 30cm \\
Dissertação (Mestrado) - Faculdade de \\
Odontologia de Bauru. USP \\
Orientador: Prof. Dr. Luiz Fernando Pegoraro
\end{tabular}

Autorizo, exclusivamente para fins acadêmicos e científicos, a reprodução total ou parcial desta dissertação, por processos fotocopiadores e/ou meios eletrônicos.

Assinatura do autor (a):

Data: 


\section{PAULO HENRIQUE ORLATO ROSSETTI}

8 de dezembro de 1975

Bauru - SP

$1994-1997$

$1998-2000$

Associações
Nascimento

Curso de Odontologia - Faculdade

de Odontologia de Bauru - SP

Estagiário do Departamento de Prótese da Faculdade de Odontologia de Bauru-USP

APCD Associação Paulista dos Cirurgiões-Dentistas do Estado de São Paulo 
Dedico este trabalho,

Ao meu pai, JOÃO, pela sua bravura, paciência e dedicação em superar as artimanhas do destino e por sempre acreditar e ensinar a nós, os filhos, que os percalços da vida são um estímulo às grandes conquistas.

A minha mãe, ALICE, pela sua bravura, paciência e dedicação e por ensinar que é preciso ser capaz de dividir o coração com os que mais necessitam.

Ao meu irmão, FERNANDO, por ser uma pessoa divertida e de bomsenso. O que falta em minha formação científica, está em você. A vitória é certa.

A LEYLHA, minha amada, é profundo e infinito meu afeto por ti, assim como a brisa das manhãs que acaricia as folhas do outono. Meu coração estará sempre bem guardado junto ao teu, meu amor.

A todos vocês, meu muito obrigado !!! 


\section{à DEUS,}

Por me ensinar que a energia do inexplicável e do possível se unifica na aliança do homem com o espaço, onde a ciência não alcança, onde as equações e postulados tornam-se obsoletos, onde a mente não raciocina e a lógic a beira o caos. O eterno círculo da vida.

Amém.

Meu muito obrigado 


\section{AGRADECIMENTOS}

A Faculdade de Odontologia de Bauru, Universidade de São Paulo, representada na pessoa da Profa. Dra. Maria Fidella de Lima Navarro, Diretora desta Faculdade.

Ao Departamento de Prótese da Faculdade de Odontologia de Bauru, representado na pessoa do Prof. Dr. Accácio Lins do Valle, Chefe do Departamento. Muito obrigado pelo carinho com que tem me tratado. Sua administração renovou e trouxe esperança para os ma is novos.

Aos Professores Doutores do Departamento de Prótese: Accácio Lins do Valle, Carlos dos Reis Pereira de Araújo, Gerson Bonfante, José Henrique Rubo, José Valdes Conti, Luiz Fernando Pegoraro, Lucimar Falavinha Vieira, Milton Carlos Gonçalves Salvador, Paulo César Rodrigues Conti, Paulo Martins Ferreira, Renato de Freitas, Valércio Bonachela, Vinícius Carvalho Porto e Wellington Cardoso Bonachela. Muito obrigado por me escutarem e dividirem seus ensinamentos. O que importa não são os títulos conquistados, mas a amizade que tenho para com vocês e levarei até o fim dos meus dias.

Ao Prof. Dr. Paulo Amarante de Araújo, do Departamento de Materiais Dentários da FOB-USP, pelo auxílio na realização da análise microscópica e fotografias. Muito obrigado. 
Ao Prof. Dr. Carlos Eduardo Francischone, Diretor-Chefe do Branemark Osseointegration Center (USC-Bauru) e Prof. Titular do Departamento de Dentística, FOB-USP, pela confiança em mim depositada. Muito obrigado..

Ao Prof. Dr. José Roberto Pereira Lauris, do Departamento de Odontologia Social da FOB-USP, pela análise estatística.

A Faculdade de Odontologia de São José dos Campos, Universidade Estadual Paulista, UNESP. Ao Prof. Dr. Marco Antonio Bottino e Prof. Dr. Maximilliano Piero Nasser, do Departame nto de Prótese Dentária desta Faculdade. Ao aluno do Curso de Doutorado desta Faculdade, Marcos Koiti Itinoche., sem os quais parte deste trabalho seria inconcebível.

A Faculdade de Odontologia de Piracicaba, Universidade de Campinas, UNICAMP.

Ao Prof. Dr. Mário Fernando de Góes e Prof. Dr. Lourenço Correr Sobrinho, do Departamento de Materiais Dentários. Ao pós-graduando Vinícius de Hipólito, da FOP-UNICAMP, pelo auxílio na preparação dos corpos de prova e microscopia eletrônica de varredura.

As secretárias do Departamento de Prótese: Angela, Edna, Cláudia, Debora, pelo pronto atendimento e pela paciência nas situações de urgência. 
Aos funcionários e ex-funcionários do Departamento de Prótese: seu Geraldo, Marcelo, Reivanildo, seu Didi e Valquíria.

Aos funcionários da Pós Graduação: Ana Maria, Aurélio, Cleusa, Giane, Letícia.

Aos meus colegas de Mestrado: Jefferson, Luis Gustavo, Leylha, Luciana, Mariana, Mauro, Osvaldo, Renato, Rafael, Stella e Tatiany.

Aos meus colegas do Doutorado : Anuar, Carlos, Gildo, Juliano, Nelson, Rudys, Stefânia e William.

A todos os colegas da pós-graduação.

Ao funcionário do Departamento de Endodontia, Edmauro, pelo auxílio no preparo das amostras desta pesquisa.

Aos ceramistas Luciano Damaluk Salters e Sidnei Martins, pela amizade e pelo auxílio em algumas etapas desta pesquisa.

A FAPESP (Fundação de Amparo a Pesquisa do Estado de São Paulo) pela concessão da Bolsa para realização deste trabalho - Processo 01/01967-5 ).

A todos os professores da Faculdade de Odontologia de Bauru que acreditam e trabalham para manter viva a alma desta instituição. 
Ao Prof. Dr Wellington Cardoso Bonachela,

Meu amigo, seu companheirismo e sua ajuda nos momentos mais difíceis foram cruciais para o meu direcionamento científico nesta Universidade. Ensinourme a caminhar pelos caminhos tortuosos da ciência para vencer por mérito próprio, com dignidade e tranqüilidade, enfrentando as situações mais adversas.

Com carinho, meu muito obrigado.

Ao Prof. Dr. Paulo Martins Ferreira,

Inigualável por sua capacidade em me tratar como se eu fosse seu filho. Os momentos em que dividimos nossas crenças foram fundamentais para o meu enriquecimento cultural. Sempre haverá tempo para fazer mais, meu amigo. Conte comigo.

Com carinho, meu muito obrigado. 
Ao meu orientador e Prof. Dr. Luiz Fernando Pegoraro,

Caro Luiz,

Quando muitos o imaginam sério ou inconformado, eu vejo uma pessoa simples, de bom coração, e que por mais que tente não consegue esconder as preocupações com tudo e com todos, porque eu sinto da mesma forma.

Durante a realização deste trabalho, vários contratempos surgiram, mas permanecemos firmes. O destino sempre é capaz de ensinar as coisas de maneira diferente, não é mesmo?

Poder ser teu orientado é uma honra. Mantê-la é uma tarefa difícil, mas não impossível. Vale até o último minuto, o último segundo, o último rabisco no pedaço de papel, o último fio de esperança.

Tu me ensinaste que a perseverança é a mais bela de todas as batalhas.

\section{Muito obrigado, meu amigo}




\section{SUMÁRIO}

LISTA DE FIGURAS

xiii

LISTA DE TABELAS

XV

LISTA DE ABREVIATURAS E SÍMBOLOS

xvii

RESUMO

1 INTRODUÇÃO

xviii

2 REVISÃO DE LITERATURA

1

3 PROPOSIÇÃO

5

4 MATERIAL E MÉTODOS

57

5 RESULTADOS

59

6 DISCUSSÃO

80

7 CONCLUSÕES

85

ANEXOS

109

REFERÊNCIAS BIBLIOGRÁFICAS

112

ABSTRACT

119

143 


\section{LISTA DE FIGURAS}

Figura 1 - Dente preparado

Figura 2 - Esquerda (a) = Marcações realizadas na coroa e dente preparado.

Direita $(b)=$ microscópio utilizado para leitura da discrepância de assentamento 66

Figura 3 - Dispositivo utilizado para cimentação $\quad 69$

$\begin{array}{lll}\text { Figura } 4 \text { - } \quad \text { Detalhe do dispositivo utilizado } & 69\end{array}$

$\begin{array}{lll}\text { Figura } 5 \text { - } \quad \text { Máquina de ensaios para ciclagem mecânica } & 71\end{array}$

Figura 6 - Fixação do corpo de prova para ciclagem mecânica 72

$\begin{array}{lll}\text { Figura } 7 \text { - } & \text { Detalhe do corpo de prova após o corte } & 73\end{array}$

Figura 8 - Esquerda: (a) = medida linear da penetração do corante ao longo da interface dente cimento, em micrometros. Direita: (b) $=$ fotomicrografia da área marginal vestibular aberta, amostra $n^{\circ} 6$, cimento fosfato de zinco, aumento 80X. 75

Figura 9 - Molde para vazamento das réplicas 76

Figura10 - $\quad \mathrm{h}=$ discrepância vertical, $\mathrm{b}=$ abertura marginal (espessura de película $\begin{array}{ll}\text { nas margens) } & 78\end{array}$

Figura 11 - Eletromicrografia da área marginal vestibular aberta, amostra $n^{\circ} 5$, fosfato de zinco ; a = abertura marginal, $137,42 \mu \mathrm{m} \quad 79$

Figura 12A Fotomicrografia da área marginal lingual adaptada, amostra $\mathrm{n}^{\circ} 7$, cimento fosfato de zinco, aumento 80X 97

Figura 12B- Eletromicrografia da mesma área, aumento 100X 97

Figura 13A- Fotomicrografia da ára marginal lingual, amostra $\mathrm{n}^{\circ} 19$, cimento ionômero devidro, aumento 80X 97

Figura 13B- Eletromicrografia da mesma área, aumento 100X 97 
Figura 14A- Fotomicrografia da área marginal lingual, amostra $\mathrm{n}^{\circ} 19$, cimento ionômero de vidro, aumento $80 \mathrm{X}$ 98

Figura 14B- Eletromicrografia da mesma área, aumento 100X 98

Figura 15A- Fotomicrografia da área marginal vestibular, amostra $n^{\circ} 29$, cimento resinoso, aumento $80 \mathrm{X}$ 98

Figura 15B- Eletromicrografia da mesma área, aumento 100X 98

Figura 16A- Fotomicrografia da margem vestibular, amostra $\mathrm{n}^{\circ} 24$, cimento resinoso, aumento $80 \mathrm{X}$ 100

Figura 16B Eletromicrografia da mesma área, aumento 100X 100

Figura 17 - Eletromicrografia da região oclusal, amostra $n^{\circ} 8$, cimento ionômero de vidro, aumento $50 \mathrm{X}$ 106

Figura 18 - Eletromicrografia da região oclusal, amostra $n^{\circ} 6$, cimento fosfato de zinco, aume nto 100X 107

Figura 19- Eletromicrografia da região oclusal, amostra $n^{\circ} 24$, cimento resinoso, aumento $120 \mathrm{X}$ 


\section{LISTA DE TABELAS}

Tabela 1 - Distribuição numérica dos dentes de acordo com sua medidas

Tabela 2 - Distribuição das amostras nos diferentes grupos, de acordo com a classificação adotada

Tabela 3 - Cimentos utilizados e seus respectivos fabricantes

Tabela 4- Médias de discrepância de assentamento (DA) e abertura marginal (AM) por agente cimentante, em micrometros

Tabela 5- Médias de penetração linear do corante na área marginal, para cada agente cimentante, observadas ao microscópio óptico (PLC). Letras iguais representam diferenças estatisticamente significativas $(p=0,005)$

Tabela 6 - Coeficientes de correlação.de Spearman. para o cimento fosfato de zinco

Tabela 7- Coeficientes de correlação.de Spearman.para o cimento ionômero de vidro

Tabela 8- Coeficientes de correlação.de Spearman .para o cimento resinoso

Tabela 9- Médias dos valores de infiltração (PLC) em função da presença de ciclagem mecânica ou não. Letras iguais representam diferenças estatisticamente significativas. Teste de Miller $(\mathrm{p}<0,05)$

Tabela 10- Resultados em micrometros da discrepância de assentamento das coroas cimentadas com cimento fosfato de zinco

Tabela 11 - Resultados em micrometros da discrepância de assentamento das coroas cimentadas com cimento ionômero de vidro 
Tabela 12 - Resultados em micrometros da discrepância de assentamento das coroas cimentadas com cimento resinoso

Tabela 13 - Valores individuais de abertura marginal (AM) em micrometros para as faces vestibular e lingual, em função do agente cimentante utilizado

Tabela 14- Valores individuais de infiltração em micrometros observados ao microscopio óptico (PLC), em função do agente cimentante utilizado

Tabela 15- Valores individuais de infiltração em micrometros observados ao microscopio eletrônico de varredura (MEV), em função do agente cimentante utilizado

Tabela 16 - Valores individuais das médias gerais de discrepância de assentamento (DA) em função das dimensões de cada amostra 119 


\section{LISTA DE ABREVIATURAS E SÍMBOLOS}

${ }^{\circ} \mathrm{C}$ - graus Celsius

HEMA - 2,3 hidroxietilmetacrilato

$\mathrm{Hz}-$ hertz

${ }^{131} \mathrm{INa}$ - isótopo radioativo do Iodo

${ }^{45} \mathrm{Ca}$ - isótopo radioativo do Cálcio

$\mathrm{Kg}$ - kilograma

Kgf - kilograma-força

KHN - (Knoop hardness number) número de dureza Knoop

$\mathrm{MPa}$ - megapascal

$\mathrm{mA}$ - miliampère

$\mathrm{Mol} / \mathrm{L}$ - moles por Litro

ìm - micrometro

mbar - milibar

mm - milímetro

$\mathrm{N}$ - newton

$\mathrm{Ni}-\mathrm{Cr}$ - liga de níquel-cromo

$\mathrm{Pd}-\mathrm{Ag}$ - liga de paládio-prata

$\mathrm{pH}$ - pontencial hidrogeniônico

$\%$ - porcento

TEGDMA - trietilenoglicol dimetacrilato

V - volt 


\section{RESUMO}




\section{RESUMO}

O propósito deste estudo foi avaliar "in vitro" as mensurações e possíveis correlações entre discrepância de assentamento, abertura marginal e padrão de microinfiltração, em coroais metalocerâmicas cimentadas com três tipos de agentes cimentantes: fosfato, ionômero e cimento resinoso dual. Trinta dentes pré-molares humanos extraídos foram preparados para coroas metalocerâmicas e as fundições foram realizadas com liga de $\mathrm{Ni}-\mathrm{Cr}$. As amostras foram divididas em três grupos, de acordo com o agente cimentante e a cimentação foi realizada sob uma carga de $5 \mathrm{Kg}$ por 10 minutos e as amostras armazenadas em água por 24hs. A discrepância de assentamento foi registrada antes e após a cimentação em um microscópio óptico com precisão de 0,001micrometro. Metade dos espécimes dentro de cada grupo foi submetida ao teste de fadiga cíclica $(50.000$ ciclos, $2,5 \mathrm{~Hz})$. As coroas foram seccionadas longitudinalmente no sentido vestíbulo-lingual e na interface coroadente-cimento foi aplicado um corante (rodamina B) por 15 segundos. A penetração do corante foi quantificada ao longo da interface sob um microscópio óptico (80 vezes de aumento) e, posteriormente, as amostras foram preparadas para microscopia eletrônica de varredura a fim de quantificar a abertura marginal e a qualidade da interface. Os resultados de discrepância de assentamento foram maiores para o cimento fosfato de zinco, seguido do ionômero de vidro e resinoso, sem diferença estatística. Foram encontradas diferenças estatisticamente significantes entre a discrepância de assentamento e a abertura marginal para os três cimentos. Os resultados de infiltração foram maiores para o cimento fosfato de zinco, seguido do ionômero de vidro e resinoso, com diferenças estatisticamente significantes. A 
ciclagem mecânica aumentou a infiltração marginal para o cimento fosfato de zinco, com diferença estatisticamente significativa em relação ao cimento ionomérico e resinoso. A análise ao microscópio eletrônico de varredura detectou melhor qualidade de união na interface dente-cimento para o sistema resinoso, seguido pelo cimento ionomérico e resinoso. 
INTRODUÇÃO 


\section{INTRODUÇÃO}

As coroas metalocerâmicas constituem um dos meios restauradores indiretos de larga aplicação na odontologia contemporânea, tendo sua indicação quando o comprometimento das estruturas dentárias tornar impossível o emprego de materiais restauradores como o amálgama, resina composta e as "inlays" e "onlays" de resina composta ou porcelana, ou quando o elemento em questão tornar-se estratégico para o planejamento de tratamentos reabilitadores diversos.

Embora estas restaurações sejam utilizadas com frequência, a interface dente-cimento-restauração sempre foi motivo de discussão, controvérsias e muita pesquisa, já que o agente cimentante interposto acaba por criar deficiências de selamento marginal, que podem levar ao acúmulo de placa bacteriana e consequente formação de lesões cariosas $3,10,18,19,39,54,91,136$. A relação deste aspecto com a abertura marginal de cada agente cimentante sempre foi um assunto controverso na literatura e dificilmente pode-se estabelecer uma relação entre causa e efeito ${ }^{7,86,87}$, já que a cárie é uma doença multifatorial, embora as pesquisas de avaliação clínica a longo prazo mostrem que a porcentagem de fracassos de prótese fixa decorrentes de cárie ser alta.

Uma das maneiras utilizadas para verificar tal relação consiste na avaliação da microinfiltração marginal em função da penetração de um corante na interface dente-cimento-restauração. Porém, estudos "in vitro" ou "in vivo" mostram resultados variados entre cimentos e materiais restauradores devido a falta de 
padronização do corante, tempo de aplicação, técnica de avaliação empregada, presença ou não de ciclagem térmica e ou mecânica, estabelecimento de escores variados de penetração e do tipo de análise realizada na interface dente-cimento (quantitativa ou qualitativa) 11,12,13,27,34,35,43,61,66,92,97,106,107,120,127,128,141 . Como consequência, muitas dúvidas e contradições têm sido apontadas na literatura em função da dificuldade de se obter resultados semelhantes de microinfiltração, tanto "in vivo" como "in vitro". Do ponto de vista clínico o cimento fosfato de zinco tem sido ao longo das últimas décadas o material mais empregado na cimentação de restaurações metálicas fundidas e próteses fixas, apesar de apresentar algumas limitações muito bem documentadas na literatura $52,57,100,115,116$.

Atualmente, os cimentos ionoméricos e resinosos estão sendo utilizados cada vez mais para a cimentação dessas restaurações. Os cimentos de ionômero de vidro modificados por resina têm tido sua popularidade aumentada entre os profissionais devido, principalmente, à sua capacidade de liberar flúor, que auxilia na prevenção de cárie. Outras características como a adesão físico-química à dentina e ao esmalte, pequena linha de cimento, expansão térmica e baixa solubilidade também são apontadas como vantajosas na escolha deste cimento $6,15,24,63,71,73,79,82,101,111,118$, 132 .

Mais recentemente surgiram no mercado os cimentos resinosos que, inicialmente, foram indicados para cimentação de próteses adesivas e, posteriormente, em decorrência dos bons resultados alcançados devido às suas 
propriedades adesivas e baixa solubilidade, começaram também a ser indicados para a cimentação de próteses fixas metalocerâmicas 39, 64, 70, 72,78,80, 94, 96, 110, 114, 120, 125 .

Quando colocada em função, uma coroa total metálica é submetida à forças complexas, cujas condições existentes na cavidade oral com variações de temperatura e componentes ácido-enzimáticos na saliva, facilitam a ação de bactérias na região cervical e, em especial, na interface restauração-cimento-dente. Com o tempo, os agentes cimentantes solubilizam-se e formam crateras internas, que acabam atuando como pontos de concentração de estresses, onde o estímulo repetido acaba por unir estas falhas, levando à fadiga do cimento, e consequentemente ao insucesso da restauração, normalmente pela presença de cárie, doença periodontal ou perda da retenção da coroa.

Ocorre que as pesquisas realizadas "in vitro", mesmo aquelas que utilizam ciclagem térmica, não reproduzem as condições existentes na cavidade oral, especialmente as relacionadas com a intensidade e tipos de forças que são aplicadas nos dentes. Assim, a tendência atual é que as pesquisas laboratoriais apresentem em seu protocolo testes de ciclagem com carga dinâmica ${ }^{31,36,37,42,47,58,65,68,73,134-141}$, para que se avalie também a influência do estresse no material. Assim, o objetivo desta pesquisa foi o de avaliar a influência da abertura marginal na infiltração, em coroas metalocerâmicas cimentadas com três tipos de agentes cimentantes, submetidas ou não à ciclagem mecânica. 
REVISÃO DE LITERATURA 


\section{REVISÃO DE LITERATURA}

A qualidade de selamento marginal que um material restaurador pode proporcionar, permanecendo íntegro com o passar dos anos e garantindo a longevidade da restauração, sempre foi a grande preocupação da odontologia.

Cientes desta questão, NELSEN; WOLCOTT, PAFFENBARGER ${ }^{81}$ (1952), a fim de estudar esta peculiaridade dos materiais, estabeleceram um protocolo de testes, onde renomados clínicos fariam preparos em dentes extraídos para os mais diferentes materiais restauradores. Os dentes, após receberem o material restaurador, foram colocados em água gelada $\left(4^{\circ} \mathrm{C}\right)$, secos e levados a uma temperatura de $52^{\circ} \mathrm{C}$, sob aquecimento lento. Quando vistas ao microscópio, nas interfaces observavam-se bolhas que extravasavam do interior das restaurações. No caso das restaurações provisórias confeccionadas para coroas totais de porcelana, verificava-se a presença de fluídos na linha cérvico-vestibular, bem como descoloração da resina, odor desagradável, manchamento interno e dissolução do cimento provisório. Concluíram que as trocas de temperatura entre o dente e o material restaurador e as diferenças nos coeficientes de expansão térmica causavam a entrada de fluídos, para todos os materiais testados. Alertaram ainda que, em escala comparativa, o diâmetro de microorganismos cariogênicos, como os lactobacilos $(2 \mu \mathrm{m})$ era suficiente para que a fenda formada entre o material restaurador e o dente fosse ultrapassada, tornando-se um mecanismo possível para a recorrência de cárie nestas restaurações. 
De maneira semelhante a questão da microinfiltração, soma-se o fato da obtenção de uma espessura de película ótima, que poderia diminuir o desgaste do agente cimentante nas áreas marginais, sem comprometer a retenção e estabilidade da coroa total metálica após a cimentação. Assim, JØ RGENSEN ${ }^{55}$ (1960), realizou um estudo onde dentes de plástico foram preparados em um torno para padronização de suas conicidades em 10 graus, sendo uma coroa de latão utilizada para cimentação de cada amostra, mediante a aplicação de cimento fosfato de zinco. Todos os espécimes foram cimentados com pressão de $2 \mathrm{Kg}$ por 10 minutos. $\mathrm{O}$ autor verificou que algumas coroas sofreram assentamento oblíquo e atribuiu este fator ao desenvolvimento de forças hidrodinâmicas quando da justaposição de duas superfícies cônicas, tendo um meio líquido como intermediário. Concluiu ainda que esta discrepância era influenciada pelo tipo de material, pressão e duração da cimentação, viscosidade e temperatura do cimento, inclinação das paredes do preparo e uso de perfuração oclusal prévia à cimentação.

KAUFMAN; COELHO; COLIN ${ }^{59}$ (1961), em estudo semelhante, utilizaram troquéis torneados em alumínio com alturas de preparo variadas $(4,7$ e $10 \mathrm{~mm})$, bem como diversas inclinações para as paredes axiais (1, 5, 10, 17 e 20 graus). Os padrões de cera foram obtidos vertendo-se cera liquefeita em uma matriz posicionada sobre o troquel. Após fundição, cimento fosfato de zinco foi pincelado no interior das coroas, que foram assentadas com pressão digital e colocadas sob ação de uma carga de 20kg, por 10 minutos. As médias de desajuste marginal foram registradas, bem 
como a espessura da película de cimento na superfície oclusal e a resistência a remoção em função das alturas e das conicidades dos preparos. Com relação ao desajuste, puderam verificar que: o desajuste aumentava significativamente à medida que as paredes axiais aproximavam-se do paralelismo e que a camada de cimento na superfície oclusal era excessiva em coroas não perfuradas, violando as relações marginais.

FUSAYAMA; IDE; $\operatorname{HOSODA}^{32}$ ( 1964 ), investigaram a influência de cargas aplicadas na cimentação, da altura e conicidade dos preparos, e do alívio interno na adaptação marginal de coroas totais. Dentes molares superiores humanos extraídos foram utilizados, sendo as moldagens realizadas com hidrocolóide irreversível e os troquéis obtidos em gesso de presa rápida. O alívio foi realizado pela aplicação de verniz nos troqueís, os padrões de cera obtidos e as fundições realizadas com liga de cobre. Todas as coroas foram cimentadas com fosfato de zinco, com ajuda de uma carga estática variando entre 15 e $50 \mathrm{Kg}$ até a presa do cimento e seccionadas no sentido vestíbulo-lingual. Concluíram que: o uso de pressão excessiva durante a cimentação não mostrou diferenças significantes com relação a espessura de película na área cervical; o aumento da conicidade diminuiu a espessura de cimento na área cervical ; um decréscimo na altura diminuiu a espessura de película na área cervical; o alívio foi eficaz em diminuir a espessura de película, havendo maior quantidade de cimento exposto na áreas onde o término era confeccionado em ombro em vez de chanfrado. 
CHRISTENSEN $^{10}$ (1966), observou que a capacidade do cirurgião-dentista em verificar a adaptação das restaurações metálicas fundidas estava diretamente associada a sua experiência com este tipo de material, sendo que o grau de concordância quanto aos valores de sondagem das margens localizadas próximas a gengiva era maior do que em outras partes das fundições. Recomendou ainda que, quando possível, o exame das margens deveria ser realizado com visão direta, pois a exploração em áreas inacessíveis ao olho humano, bem como o uso de radiografias, constituíam meios menos confiáveis.

$\mathrm{KIDD}^{60}$ (1976), em artigo de revisão, citou que os estudos até a época realizados enfatizavam que as margens das restaurações não eram bordas fixas, inertes ou impenetráveis, mas microfendas dinâmicas, que continham um tráfego conturbado de íons e moléculas. Ressaltavam ainda que nos últimos 25 anos, estudos variados (através de corantes orgânicos, isótopos radiativos, cáries artificiais, câmaras de pressão, ciclagem térmica e microscopia eletrônica de varredura) mostraram que a microinfiltração sempre ocorreu em maior ou menor grau, independente do material restaurador. Com o desenvolvimento das resinas compostas, existia a esperança de que a adesão química entre o dente e a restauração fosse capaz de suportar a umidade e as variações de temperatura.

A fim de verificar se a proteção do complexo dentino-pulpar era eficaz no combate à microinfiltração através da aplicação de diversos materiais nas paredes do preparo, previamente à cimentação de coroas totais metálicas, MONDELLI; ISHIKIRIAMA; GALAN JÚNIOR ${ }^{76}$ (1978), utilizaram 80 dentes molares humanos 
de dimensões semelhantes. Durante o estudo, as amostras foram mantidas em solução fisiológica a $37^{\circ} \mathrm{C}$, com $100 \%$ de umidade. Os dentes receberam preparos para coroas totais, sendo de 5 graus a inclinação das paredes axiais e o término cervical em 135 graus . Os padrões de cera obtidos tinham a superfície oclusal plana, sendo confeccionados diretamente sobre os preparos, e as fundições realizadas com uma liga de ouro tipo III. Para limpeza das superfícies internas foi utilizada solução de $\mathrm{HCl}$ a $50 \%$ e jatos de óxido de areia. Todas as amostras foram cimentadas com fosfato de zinco, sob ação de uma carga estática de $15 \mathrm{~kg}$, durante 10 minutos. Em dez amostras, não foi utilizado agente de proteção, servindo como grupo controle. Foram estabelecidos sete grupos com dez amostras cada, sendo que um dos grupos recebeu aplicação de um agente bacteriostático (Tubulicid). Os demais grupos formavam pares, sendo que o agente em questão (verniz cavitário Copalite, verniz para forramento de cavidades Tubulitec, ou solução de hidróxido de cálcio Pulpdent) era aplicado $1 \mathrm{~mm}$ acima das margens cervicais ou em toda a extensão das paredes do preparo. Os corpos de prova foram imersos em uma solução contendo isótopo radiativo ${ }^{131} \mathrm{INa}$, uma hora após a cimentação e 24 horas após a cimentação . Uma tabela contendo escores foi assim estabelecida : 0- nenhuma evidência do isótopo na interface dente-restauração; 1- alguma evidência do isótopo na interface denterestauração; 2- evidência do isótopo em todas as paredes de esmalte, mas não em dentina; 3- evidência em todas as paredes dentinárias. Concluíram que os coroas cimentadas com fosfato de zinco mostraram infiltração marginal variada, dependendo do material de proteção utilizado. Os melhores resultados foram verificados quando eram aplicadas duas camadas de verniz cavitário nas margens 
cervicais. A quantidade de infiltração marginal pode ser influenciada pela adaptação da coroa e espessura da película de cimento. Não existiram diferenças entre os períodos testados de uma hora e 24 horas após a cimentação.

EAMES et $\mathrm{al}^{22}$ (1978), prepararam molares humanos com ângulos de convergência de 10 e 20 graus, com ou sem aplicação de espaçador nos troquéis , para cimentação de coroas totais metálicas fundidas em liga de ouro tipo III. Os cimentos utilizados foram: fosfato de zinco, silicofosfato, cimento resinoso CBA e policarboxilato de zinco . A técnica de cimentação descrita consistia na aplicação de cargas progressivas em escala decrescente $(27 \mathrm{~kg}$ a $7 \mathrm{~kg})$, totalizando 10 minutos. $\mathrm{O}$ espaço oclusal interno foi checado antes e após a cimentação. Com respeito ao uso de espaçador, verificaram que as coroas cimentadas com fosfato de zinco e policarboxilato exibiram média de desajuste oclusal de 33 e $20 \mu \mathrm{m}$, respectivamente, quando o alívio interno foi realizado. Quando da não utilização do alívio, os valores permaneceram na faixa de $112 \mu \mathrm{m}$. Concluíram então que o método de espaçamento utilizado poderia ser útil para compensar o que os autores chamaram de efeito rebote, responsável pela discrepância e não assentamento completo das restaurações.

OLIVEIRA et $\mathrm{al}^{83}$ (1979), realizaram estudos para verificar a influência da pressão e vibração durante a cimentação de coroas totais metálicas e restaurações tipo MOD, na qualidade final de adaptação das mesmas, sendo que o valores de desajuste marginal foram verificados antes e após a cimentação. Foram utilizados os seguintes métodos complementares para assentamento das fundições: sendo: bastão 
de laranjeira, rolo de algodão, disco de borracha e calcador do tipo Medart. Todas as coroas foram cimentadas com ajuda de um aparelho de vibração (Electromallet) e carga estática de $9,0 \mathrm{Kg}$, sendo encontrados os seguintes resultados para as coroas totais metálicas: calcador Medart $(43,5 \mu \mathrm{m})$, bastão de laranjeira e disco de borracha $(59,7$ e $68,2 \mu \mathrm{m}$, respectivamente) e rolo de algodão $(78,1 \mu \mathrm{m})$. Os autores concluíram que o uso de vibração e dispositivo Medart mostrourse eficiente na diminuição das discrepâncias marginais.

PISANESCHI $^{93}$, em 1979, verificou a infiltração marginal em coroas totais cimentadas com três diferentes agentes cimentantes: fosfato de zinco, policarboxilato e ionômero de vidro. Os testes foram realizados em períodos de observação de 7 a 90 dias e o corante usado foi a rhodamina B a $0,1 \%$. Foram selecionados 66 dentes caninos e pré-molares para os testes " in vitro" e, para os testes " in vivo", 63 dentes entre incisivos, caninos e pré-molares. Para os testes em laboratório foi realizada a ciclagem térmica em saliva artificial (450 ciclos, entre as temperaturas de 5 e $55^{\circ} \mathrm{C}$ ), em períodos de 7 a 90 dias, após o que todos os dentes, incluindo os dentes avaliados "in vivo" foram extraídos e tiveram sua porção radicular protegida, para em seguida serem introduzidos em corante rodamina B a $0,1 \%$, por seis horas. Após a avaliação da infiltração marginal e análise estatística dos resultados obtidos, a autora pode concluir que a infiltração marginal foi muito maior nos testes " in vivo" do que " in vitro". Nos testes " in vitro" não houve diferença estatisticamente significante entre os padrões de infiltração nos dois períodos de armazenamento. Já "in vivo", a infiltração foi mais severa para o período de 90 dias. De modo geral, o cimento que 
se comportou melhor nos períodos testados, tanto "in vitro" quanto "in vivo", foi o ionômero de vidro.

Em 1980, TJAN et al $^{104}$ alertaram para o fato de existirem vários estudos de microinfiltração em materiais restauradores (de preenchimento de cavidades), mas poucos estudos com coroas totais fundidas com liga de ouro. Desta forma, conduziram uma investigação "in vitro", onde o selamento marginal destas mesmas coroas era verificado sob estresse térmico ou não, sendo utilizados fosfato e policarboxilato de zinco como agentes cimentantes. Para tanto, prepararam 40 dentes molares inferiores de dimensões semelhantes, utilizando término cervical em chanfrado por vestibular, e lâmina de faca por lingual e proximais, com a confecção de dois sulcos auxiliares para retenção nas paredes axiais vestibular e lingual. Os padrões de cera foram obtidos de forma indireta, sobre troquéis de gesso Velmix, e as fundições realizadas com liga de ouro tipo III, sendo cimentadas com uma carga estática de $5 \mathrm{Kg}$, por 10 minutos. Metade das amostras foi cimentada com fosfato de zinco, e a outra metade com cimento policarboxilato de zinco. Dez coroas de cada grupo foram submetidas ao estresse térmico $\left(4\right.$ e $\left.60^{\circ} \mathrm{C}\right)$, e as dez coroas restantes de cada grupo foram mantidas em temperatura constante $\left(37^{\circ} \mathrm{C}\right)$, sendo utilizada solução de fucsina básica a 0,2\% em ambas as situações. As amostras foram incluídas em resina acrílica incolor e seccionadas no sentido vestíbulo-lingual. Uma tabela com escores também foi utilizada : 0- sem penetração; 1- penetração igual ou menor do que metade da parede axial; 2- penetração em toda a extensão da parede axial; 3penetração além da parede axial, aproximando-se da fossa central; 4- penetração do 
corante até a fossa central. Concluíram que a microinfiltração foi evidente em todos os casos e que o grau de microinfiltração foi menor para o fosfato do que para o policarboxilato de zinco. Ressaltaram que a causa da microinfiltração parece ser multifatorial, já que o assentamento oblíquo das coroas foi observado em muitas ocasiões, apesar da confecção dos sulcos de retenção adicional nas paredes axiais.

$\operatorname{DEDMON}^{16}$ (1982), tentou verificar aquilo que os clínicos consideravam como desajuste aceitável, já que desajustes mínimos levariam a fundições mais precisas com menor exposição da linha de cimentação. Para isso, idealizou um dispositivo retangular metálico composto de duas metades deslizantes, onde uma delas simulava defeitos marginais verticais e a outra defeitos marginais horizontais. O autor pode observar que as médias consideradas aceitáveis pelos diferentes examinadores ficaram em torno de $104 \mu \mathrm{m}$ (faixa de 32 a $230 \mu \mathrm{m}$ ). Verificou ainda que a distinção entre um defeito marginal vertical ou horizontal não pode ser reconhecida, sendo que todas as discrepâncias foram consideradas como sobrecontornos.

JANSEN $^{50}$, em 1983 , preparou 32 dentes molares humanos para a confecção de coroas totais metálicas em liga Duracast MS. Após a fundição, as verificações do ajuste marginal nas coroas foram realizadas com auxílio de lupa e sonda exploradora. O cimento fosfato de zinco (S.S. White) foi proporcionado usando-se duas medidas do dispositivo maior do dosador para seis gotas de líquido. O cimento foi pincelado no interior das coroas de duas formas: técnica I - 
pincelamento em toda a superfície interna e técnica II - pincelamento nas superfícies laterais internas e início da superfície oclusal. As coroas foram assentadas sob pressão digital e mantidas com uma carga de $9 \mathrm{Kg}$ durante um minuto, ou utilizandose o aparelho Vibra Seat que promovia um efeito vibratório intermitente nos dez segundos iniciais da cimentação. Para as medidas de desajuste, usou-se um micrômetro de quadrante, sendo que as médias de desajuste em cada grupo foram: técnica I, sem vibração, $37,5 \mu \mathrm{m}$ e $35 \mu \mathrm{m}$ com vibração; técnica II, sem vibração 27,3 $\mu \mathrm{m}$ e 20,8 $\mu \mathrm{m}$ com vibração. As coroas cimentadas foram incluídas em plástico transparente e cada conjunto seccionado por três cortes no sentido longitudinal. As leituras foram realizadas no microscópio comparador e as regiões foram agrupadas da seguinte forma: término cervical (R1), axial (R2), vestibular e lingual da superfície oclusal (R3) e centro da superfície oclusal (R4). Os melhores resultados foram obtidos pela técnica de cimentação II, com vibração. A espessura de película foi maior na região $4(171,47 \mu \mathrm{m})$, seguida das regiões $3(117,26 \mu \mathrm{m}), 2(42,53 \mu \mathrm{m}) \mathrm{e}$ $1(32,61 \mu \mathrm{m})$. Houve completo escoamento do cimento para todas as superfícies internas das coroas. $\mathrm{O}$ autor concluiu que o fator técnica de cimentação mostrou-se significante para as regiões 1,3 e 4, enquanto que para a região 2 mostroutse não significante. O fator vibração mostrou-se significante para as regiões 2,3 e 4, enquanto que para a região 1 mostrourse não significante.

Para dar continuidade a esta linha de raciocínio, PANDOLFI ${ }^{85}$ (1983) preparou 40 dentes molares humanos com término cervical em chanfrado para avaliar o espaço existente entre a coroa metálica fundida e o dente preparado, assim 
como sua implicação na cimentação. As coroas foram divididas em dois grupos de acordo com os resultados encontrados em testes preliminares de resistência à remoção. Os dentes do grupo I com as respectivas coroas somente adaptadas aos preparos foram incluídos em resina, enquanto que os do grupo II tiveram suas coroas cimentadas antes da inclusão. Em seguida, nos dois grupos foram realizados cortes e depois realizadas medições dos espaços entre as coroas e os preparos (grupo I) e das películas de cimento (grupo II). O autor concluiu que a avaliação da adaptação das coroas usando-se critérios clínicos foi considerada satisfatória, não detectando, porém, discrepâncias cervicais menores que $45 \mu \mathrm{m}$ para as coroas do grupo I. Os valores dos espaços internos e de espessura de película mostraram diferenças significantes e em ordem crescente das regiões do término cervical para as regiões da superfície oclusal. A região axial foi considerada como a maior responsável pelos desajustes das coroas na cimentação, sendo que valores mínimos de desajuste nesta região poderão ser verificados, quando o espaço interno estiver em torno de 50 a $70 \mu \mathrm{m}$

MYERS et $\mathrm{al}^{79}$., em 1983, realizaram um estudo in vitro para verificar a infiltração marginal de quatro agentes cimentantes comumente empregados, sendo utilizada solução radiativa de ${ }^{45} \mathrm{Ca}$ para este propósito. Sessenta dentes molares permanentes superiores e inferiores receberam preparos para cavidades classe V para inlays, sendo os padrões de cera obtidos diretamente e as fundições realizadas com uma liga de ouro tipo II. Os dentes foram divididos em quatro grupos: grupo 1cimentação com fosfato de zinco; grupo 2- cimentação com policarboxilato ativado por água; grupo 3- cimentação com cimento ionômero de vidro sem aplicação de 
verniz nas margens da restauração e grupo 4 cimentação com ionômero de vidro com aplicação de verniz nas margens da restauração. A infiltração marginal foi avaliada em intervalos de um mês, seis meses, e um ano. Cada espécime foi imerso por duas horas em solução de ${ }^{45} \mathrm{Ca}$. Para avaliar o grau de infiltração, utilizaram a seguinte escala: 0- sem penetração do isótopo; I- penetração no ângulo cavosuperficial; II - penetração ao longo da parede gengival ou oclusal, mas não da parede pulpar; III- penetração do isótopo na parede pulpar. Após um ano de estudo, concluíram que os agentes cimentantes que mostraram a menor quantidade de infiltração foram o fosfato de zinco e o ionômero de vidro sobre a proteção de verniz cavitário, tendo o cimento de policarboxilato ativado por água apresentado a maior taxa de infiltração. Verificaram ainda que em todas as amostras onde não foi aplicado verniz em adição ao ionômero de vidro, as taxas de solubilidade receberam grau III. Salientaram ainda que a cimentação com ionômero de vidro constitui um passo crítico, e o clínico que optar por este material deverá utilizá-lo em dentes onde seja possível o isolamento absoluto para evitar a penetração de agentes no cimento durante a reação de presa.

TJAN; SARKISSIAN ${ }^{105}$ (1984), procuraram solucionar as discrepâncias marginais encontradas após assentamento incompleto das coroas, já que as perfurações nas mesmas levavam tempo para serem preenchidas e tornavam-se complexas em restaurações que possuíam cobertura oclusal em porcelana. Para tanto, utilizaram 30 dentes molares humanos, sendo confeccionado um sulco de escape na parede axial dos preparos. Após obtenção dos troquéis, os padrões de cera foram 
incluídos e as fundições realizadas com liga de ouro tipo III, sendo as superfícies internas limpas com solução ácida. Todas as coroas foram cimentadas com fosfato de zinco, sendo o cimento aplicado sobre a paredes internas das fundições e as coroas assentadas inicialmente com pressão digital e posteriormente sob ação de uma carga de $6 \mathrm{Kg}$, por 10 minutos. Os dentes foram divididos em cinco grupos de dez amostras: grupo 1 (controle), grupo 2 (sulco de escape na vestibular), grupo 3 (sulco de escape e verniz Copalite), grupo 4 (sulco de escape por lingual) e grupo 5 (sulco de escape com subextensão na vestibular). Foram realizados também testes de resistência à remoção por tração. As médias observadas para a discrepância marginal foram: grupo $1-115 \mu \mathrm{m}$, grupo $2-30 \mu \mathrm{m}$, grupo $3-18 \mu \mathrm{m}$, grupo $4-42 \mu \mathrm{m}$ e grupo 5$60 \mu \mathrm{m}$. Verificaram que a colocação de um sulco de escape tanto na vestibular como na parede axial lingual não influenciou nos valores obtidos para as discrepâncias marginais. De maneira semelhante, a colocação do sulco de escape não aumentou os valores de resistência à remoção por tração.

$\operatorname{DEDMON}^{17}$ (1985), continuou sua linha de estudos ${ }^{16}$ (1982) sobre a avaliação da quantidade de desajuste vertical e horizontal detectáveis "in vitro" através da utilização de uma sonda exploradora. Para isso, idealizou um dispositivo retangular metálico composto de duas metades deslizantes, onde uma delas simulava defeitos marginais verticais e a outra defeitos marginais horizontais. Desta vez, foram simuladas margens subgengivais nas áreas proximais do dispositivo, a fim de verificar se a habilidade do clínico mudava em função do acesso ilimitado ou limitado. Para as margens abertas, o número de respostas corretas para o acesso 
ilimitado foi de 12 contra 18 e para o acesso limitado de 15 contra 15 . Na simulação de sobrecontorno, o número de respostas corretas foi de 30 contra 0 (acesso ilimitado) e de 20 contra 33, no acesso limitado. Não mais do que 50\% das margens abertas foi corretamente descrito, independente da disponibilidade de acesso. Concluíram que, quando as margens não são visíveis, as discrepâncias que resultam do assentamento incompleto das fundições são mais difíceis de serem detectadas com uma sonda exploradora, e que margens mais abertas do que o necessário são provavelmente mais aceitas antes da cimentação

PHILLIPS; BISHOP ${ }^{89}$ (1985), realizaram um estudo "in vitro" para verificar o efeito da contaminação prematura dos cimentos ionoméricos pela saliva. Os agentes cimentantes testados foram: Fuji II, Aspa e Ketac. Prepararam três discos de $5 \mathrm{~mm}$ de diâmetro por $3 \mathrm{~mm}$ de profundidade para cada cimento testado, os quais foram colocados em uma estufa a $37^{\circ} \mathrm{C}$, repousando por $5,10,15,20,30,60,120$ ou 240 minutos após o início da mistura, sendo então imersos em solução de cloreto de sódio a $0,9 \%$ e inspecionados a cada 24 horas, em um estereomicroscópio e um colorímetro. Na superfície dos discos também foi aplicada solução aquosa de fucsina básica a $0,5 \%$, para verificar o tempo necessário para a maturação do cimento, de tal modo que a proteção contra perda ou ganho de água fosse desnecessária. Concluíram que existem intervalos entre o início da mistura e a reação de presa, onde os cimentos tornam-se susceptíveis à contaminação, sendo para o Fuji tipo II 30 minutos, para o Aspa 20 minutos e para a Ketac 10 minutos. Para o teste de imersão e secagem dos 
discos, microtrincas não foram mais evidenciadas após 15 dias para o Fuji tipo II, 5 dias para o Aspa e 24 horas para o Ketac.

PHILLIPS et $\mathrm{a}^{90}$ (1987), realizaram um estudo " in vivo ", para determinar a influência de certos fatores que poderiam afetar as taxas de desintegração dos cimentos fosfato de zinco, silicofosfato de zinco, policarboxilato de zinco (proporção pó-líquido 1,5:1 e 1:1) e cimento ionômero de vidro. Quarenta pacientes, divididos em dois grupos, receberam um par de coroas totais metálicas fundidas em liga de ouro, sendo que uma delas possuía em suas paredes externas mesiais e distais, quatro receptáculos onde seriam colocados os agentes cimentantes. Todas as coroas foram cimentadas provisoriamente com cimento de óxido de zinco e eugenol. Após 6 e 12 meses, as coroas eram retiradas, colocadas sobre um microscópio e medidas eram realizadas para verificação das taxas de desintegração, tendo como padrão marcas previamente estabelecidas. Terminado o estudo, as coroas totais metálicas eram cimentadas definitivamente. Concluíram que após o período de 12 meses, os cimentos ionômero de vidro e silicofosfato mostraram as menores taxas de desintegração, seguidos do policarboxilato (proporção 1,5:1) e do cimento fosfato de zinco. Quando se utilizou policarboxilato na proporção 1:1, a quantidade de desintegração triplicou.

PILO et $\mathrm{al}^{91}$ (1988), em artigo de revisão de literatura, sobre o assentamento incompleto de coroas totais metálicas, argumentaram que existem poucos estudos correlacionando discrepâncias marginais e a longevidade destas restaurações no 
ambiente bucal. Observaram que muitas das coroas que permaneceram por 8 a 15 anos cimentadas em dentes comprometidos periodontalmente, exibiam pobre adaptação marginal mas sem nenhum traço de dissolução do agente cimentante. Por outro lado, coroas com bom assentamento exibiam espaços indicativos de infiltração e dissolução do cimento. Concluíram que a integridade marginal não pode ser inteiramente responsável pela dissolução da película de cimento.

KNIBBS; WALLS ${ }^{62}$ (1989), realizaram estudos "in vivo" e "in vitro" sobre microinfiltração, utilizando cimentos de fosfato de zinco, ionômero de vidro e policarboxilato. Pequenos discos de cada agente cimentante, totalizando 24 amostras, foram submetidas a dissolução intermitente (imersão ora em solução tampão de lactato de sódio $\mathrm{pH} 4,0$, ora em água destilada $\mathrm{pH}$ 5,5), sendo metade das amostras imersa 15 minutos após a presa, e a outra metade uma hora após. Para os testes "in vivo", realizaram 250 restaurações (89 coroas totais de porcelana, 78 coroais totais de ouro, 74 coroas metalocerâmicas) que foram avaliadas por 3,5 anos, quanto ao selamento marginal. Os autores concluíram que não foram encontradas diferenças estatisticamente significantes entre os resultados obtidos tanto "in vivo" quanto "in vitro", em relação à dissolução do agente cimentante.

Segundo PASHLEY ${ }^{86}$ (1990), para o entendimento das consequências clínicas da microinfiltração é preciso analisar as características de permeabilidade da dentina. A dentina das paredes axiais é mais permeável do que a dentina que forma o assoalho da parede pulpar das cavidades, existindo aproximadamente dois a três 
milhões de túbulos dentinários por $\mathrm{cm}^{2}$. Nos preparos para coroa total, a descorticalização total do esmalte de um molar fornece uma área de superfície dentinária de 3 a 4 cm² $^{2}$ existindo a possibilidade de exposição de 6 a 12 milhões de túbulos. Embora a embocadura dos túbulos esteja protegida pela lama dentinária (smear layer), esta camada pode ser facilmente removida, seja pelo ataque ácido ou pela não aplicação de uma agente forrador ou verniz cavitário. Salientou ainda que os estudos "in vitro" deveriam ser interpretados com muito cuidado, já que alguns processos fisiológicos (como a esclerose dos túbulos dentinários ou a adesão de moléculas do sistema imune-fibrinogênio) são fatores que diminuem a permeabilidade "in vivo" aos agentes agressores.

TJAN et al ${ }^{106}$ (1991), realizaram estudos "in vitro" para verificar o grau de microinfiltração em coroas totais metálicas cimentadas com fosfato de zinco e ionômero de vidro, mediante condicionamento ácido ou modificação da superfície dentinária com pontas abrasivas. Quarenta dentes pré-molares humanos recémextraídos foram divididos em quatro grupos experimentais: (1) coroas cimentadas com fosfato de zinco, (2) coroas cimentadas com ionômero de vidro, (3) condicionamento prévio da dentina com ácido poliacrílico por 10 segundos e cimentação com ionômero de vidro e (4) polimento das paredes do preparo, condicionamento ácido e cimentação com ionômero de vidro. Os dentes foram embebidos em blocos plásticos e receberam preparos com término cervical em chanfrado. As moldagens foram realizadas com moldeira acrílica individual e silicona de polimerização por adição, sendo os troquéis obtidos com gesso tipo IV e 
as fundições realizadas com liga de ouro tipo III. Todas as coroas foram assentadas com pressão digital sobre os preparos e mantidas sobre uma carga de $5 \mathrm{Kg}$ por 10 minutos, recebendo uma camada de verniz cavitário na interface restauração-cimento para evitar a desidratação. Após a remoção dos excessos, as amostras foram colocadas em água a $37^{\circ} \mathrm{C}$ por sete dias, sendo as superfícies radiculares seladas com esmalte de unha. A termociclagem foi realizada entre as temperaturas de 5 e $55^{\circ} \mathrm{C}$, num total de 300 ciclos em banho de solução aquosa com fucsina básica a $0,5 \%$. Os espécimes foram então incluídos em resina epóxica e seccionados no sentido vestíbulo-lingual, sendo a medida da infiltração determinada pela média das faces vestibular e lingual. Observaram que as coroas cimentadas com ionômero de vidro mostraram menor infiltração do que as cimentadas com fosfato de zinco; o tipo de tratamento de superfície (condicionamento ácido ou polimento) não foi considerado estatisticamente significante para diminuição da microinfiltração.

GOLDMAN; LAOSONTHORN; WHITE ${ }^{38}$ (1992), realizaram um estudo "in vitro" para verificar se o tipo de término marginal em preparos para coroas totais contribuiria para aumento ou diminuição da microinfiltração. Trinta dentes molares humanos foram afixados em cilindros preenchidos com resina acrílica e divididos em três grupos, de acordo com o tipo de término cervical: ombro, chanfrado e ombro biselado. As fundições foram realizadas com liga de níquel-cromo e cimentadas com fosfato de zinco, sob carga estática de $15 \mathrm{Kg}$, durante 10 minutos. As amostras foram submetidas ao regime de ciclagem térmica (100 ciclos entre as temperaturas de 4 e $60^{\circ} \mathrm{C}$ ) com posterior imersão em corante cristal violeta a $0,05 \%$, lavadas e incluídas 
em resina acrílica autopolimerizável para seccionamento no sentido vestíbulolingual. Concluíram que o corante foi capaz de penetrar em todas as coroas, independente do tipo de configuração marginal adotada, sendo o sentido da microinfiltração dos túbulos dentinários em direção à polpa, para todas as amostras.

A fim de verificar se a utilização ou não se a ciclagem térmica tem influência na microinfiltração, WENDT; McINESS; DICKINSON ${ }^{117}$ (1992) prepararam cavidades do tipo MOD em 50 dentes molares humanos para colocação de restaurações de resina composta, sendo que uma das margens proximais possuía término em esmalte e a outra em cemento. Os dentes foram distribuídos em cinco grupos: A sem termociclagem e imersão em fucsina básica a $0,5 \%$ por 24 horas, grupo $A^{\prime}-$ sem termociclagem, imersão em fucsina básica a $0,5 \%$ por 4 horas, grupo B- com termociclagem e imersão em fucsina básica a $0,5 \%$ por 24 horas, grupo Ccom termociclagem e imersão em fucsina básica a $0,5 \%$ por 4 horas e grupo D- com termociclagem em fucsina básica a $0,5 \%$, imersão em fucsina básica por 24 horas. $\mathrm{O}$ processo de termociclagem foi realizado entre as temperaturas de 5 e $50^{\circ} \mathrm{C}$, com intervalo de 15 segundos entre cada troca num total de 250 ciclos. A penetração do corante foi observada mediante a utilização de escores. Concluíram que não foram encontradas diferenças estatisticamente significantes em nenhuma das condições testadas.

TJAN; DUNN; GRANT ${ }^{108}$ (1992), realizaram um estudo para verificar a habilidade de selamento marginal de um novo agente cimentante (Panavia Ex), 
quando comparado ao cimento fosfato de zinco, na cimentação de coroas totais metálicas. Trinta dentes molares humanos foram selecionados, recebendo preparos com forma de término cervical em chanfrado. As moldagens foram realizadas com silicona de polimerização por adição e o enceramento confeccionado sobre troquéis de gesso tipo IV. As fundições foram realizadas com liga de ouro tipo III, e todas as amostras foram cimentadas sob pressão digital e carga vertical estática de $5 \mathrm{Kg}$, por 10 minutos. Os grupos foram constituídos da seguinte maneira: grupo 1 - coroas cimentadas com fosfato de zinco e estocadas por 30 dias em água a $37^{\circ} \mathrm{C}$ antes da termociclagem; grupo 2 - coroas cimentadas com cimento resinoso e estocadas por 30 dias em água a $37^{\circ} \mathrm{C}$ antes da termociclagem e grupo 3 - coroas cimentadas com cimento resinoso, mas estocadas por 90 dias em água a $37^{\circ} \mathrm{C}$ antes da termociclagem. Antes da cimentação, todos os preparos foram limpos com pedra-pomes e água. A termociclagem foi realizada com solução aquosa de fucsina básica a $0,5 \%$, entre as temperaturas de 5 e $55^{\circ} \mathrm{C}$, num total de 300 ciclos. Os espécimes foram incluídos em resina epóxica e seccionados nos sentidos vestíbulo-lingual e mésio-distal, tendo como escore os seguintes valores: 0 - sem microinfiltração, 1- microinfiltração até um terço da parede axial; 2 microinfiltração até dois terços da parede axial; $3-$ microinfiltração ao longo de toda parede axial; 4 - microinfiltração sobre a superfície oclusal. Os autores concluíram que as coroas cimentadas com Panavia Ex exibiram menor infiltração marginal do que as cimentadas com fosfato de zinco. Nenhuma diferença foi observada entre os períodos de imersão (30 e 90 dias) para as coroas cimentadas com cimento resinoso. Nenhuma penetração do corante foi observada na interface restauração-cimento das coroas cimentadas com Panavia Ex. 
Em estudo semelhante, WHITE et al ${ }^{120}$ (1992) utilizaram 42 dentes pémolares humanos, estando o término dos preparo das margens vestibular e lingual localizado em esmalte, e das margens mesial e distal em dentina e cemento. As fundições foram realizadas com uma liga não-preciosa (Rexilium III - Jeneric / Pentron) e a medida do desajuste antes da cimentação $(56 \mu \mathrm{m})$ foi verificada com um microscópio, através de marcas pré-estabelecidas. Foram constituídos seis grupos de sete amostras cada, com os seguintes agentes cimentantes: Thin Film cement com e sem Tenure, Panavia Ex, Ketac Cem radiopaco, Flecks e Durelon . Os cimentos foram aplicados no interior das coroas, assentadas sobre pressão de uma carga axial de $6 \mathrm{Kg}$ por 7 minutos. As amostras foram termocicladas com água destilada por 1500 ciclos e embebidas em solução de nitrato de prata por uma hora e expostas a luz especial para fixação e estudo da microinfiltração. Após secção dos dentes nos sentidos vestíbulo- lingual e mésio-distal, o grau de penetração foi definido como a distância linear percorrida pelo corante, partindo-se da interface dente-restauração. Os autores concluíram que o cimento fosfato de zinco exibiu maior infiltração marginal do que os outros agentes cimentantes. O Thin Film cement com Tenure foi o mais resistente a microinfiltração, seguido do Panavia Ex, ionômero de vidro, Thin Film sem Tenure, fosfato de zinco e cimento policarboxilato. As margens do preparo colocadas em dentina não registraram significativamente maior grau de microinfiltração do que aquelas localizadas em esmalte. A microinfiltração predominou na interface dente-cimento. 
Preocupados com o uso indiscriminado de novos agentes cimentantes introduzidos no mercado, principalmente os resinosos, mediante a justificativa de que os mesmos melhorariam a retenção e diminuiriam a infiltração, WHITE; YU ${ }^{121}$ (1992), propuseram-se a medir a espessura de película de cada cimento, seguindo a metodologia preconizada pela norma $\mathrm{n}^{\circ} 8$ da American Dental Association. Foram testados os seguintes cimentos: fosfato de zinco (Flecks, Tenacin, Shofu Hy-Bond), hidroxiapatita (Bioment), policarboxilato (Durelon, Shofu), ionômero de vidro (Ketac-Cem, Fuji I, Shofu) e resinosos (C\&B Metabond, Thin Film Tenure, Panavia Ex, Ultrabond, All-Bond, Infinity, Marathon, Geristore). Verificaram que películas acima de $40 \mu \mathrm{m}$ foram observadas para quase todos os cimentos resinosos, com exceção do Geristore $(20,5 \mu \mathrm{m})$ e Infinity $(30,7 \mu \mathrm{m})$, sendo o maior valor encontrado para o cimento resinoso Marathon $(106,7 \mu \mathrm{m})$. Os valores de película para os outros

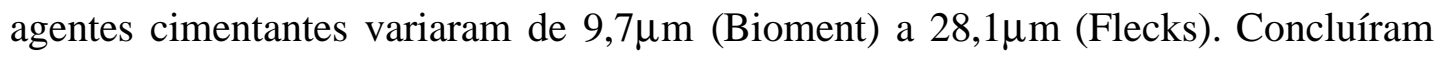
que, embora os novos agentes cimentantes resinosos fossem benéficos do ponto de vista de resistência ao desgaste e microinfiltração, o controle das propriedades físicas e químicas ainda deveria ser motivo de vários estudos, a fim de que alguns fatores como a viscosidade e o grau de polimerização fossem controlados, para obtenção de melhores valores de espessura de película.

WHITE; YU; KIPNIS ${ }^{122}$ (1992), investigaram os efeitos das forças de assentamento na espessura de película de alguns agentes cimentantes adesivos, seguindo a metodologia preconizada pela norma $n^{\circ} 8$ da American Dental Association. Foram avaliados: cimento fosfato de zinco, ionômero de vidro, 
policarboxilato e cimento resinoso com agente de união. Após a mistura de cada cimento, os discos foram colocados entre duas placas de vidro e comprimidos com 1 , 3, 5, 9, 15 e $23 \mathrm{Kg}$, sendo a espessura de película obtida para cada carga registrada. Verificaram que o comportamento dos materiais variou entre 1 e $9 \mathrm{Kg}$, sendo os valores de película semelhantes na faixa de 15 a $23 \mathrm{~kg}$. O cimento ionômero de vidro atingiu espessura de película recomendada com menor quantidade de força de compressão empregada, sendo o inverso observado para o cimento resinoso; fosfato de zinco e policarboxilato registraram posições intermediárias. Os menores valores registrados foram: policarboxilato $(15,8 \mu \mathrm{m})$, ionômero de vidro $(16,9 \mu \mathrm{m})$, fosfato de zinco $(27,0 \mu \mathrm{m})$ e cimento resinoso mais agente de união $(36,4 \mu \mathrm{m})$.

CAGIDIACO et $\mathrm{al}^{8}$ (1992), realizaram um estudo em coroas metalocerâmicas para verificar se o tipo de término cervical (ombro ou ombro biselado) levaria a uma maior espessura de cimento e consequentemente, maior grau de infiltração marginal. Dez dentes periodontalmente envolvidos foram preparados, sendo a margem vestibular com o término em ombro e a margem lingual, com o término em ombro biselado. Todas as coroas foram cimentadas com fosfato de zinco. Após 3 a 6 semanas, os dentes foram extraídos e mantidos em solução de azul de metileno por dois dias, lavados, incluídos em resina e seccionados duas vezes longitudinalmente no sentido vestíbulo-lingual. Uma das metades foi observada em microscopia eletrônica de varredura, e a outra metade submetida a avaliação da microinfiltração por intermédio de escores. Os autores puderam verificar que o grau de infiltração foi maior nas margens vestibulares no que nas linguais, sendo restrito 
as áreas do ombro. Embora as médias de espessura do cimento estivessem dentro dos parâmetros estabelecidos na literatura, nenhum menção foi realizada sobre uma possível correlação entre a espessura de cimento e o grau de microinfiltração.

CURTIS; RICHARDS; MEIERS ${ }^{15}$ (1993), prepararam 50 dentes molares humanos, sendo que em cada espécime metade das margens do preparo localizava-se em esmalte, e a outra metade em cemento. Após a moldagem com polissulfeto e obtenção dos troquéis em gesso tipo IV, as fundições foram realizadas com uma liga de metal básico (Pentillium - Jeneric / Pentron) e todas as coroas foram assentadas com pressão digital e cimentadas com carga estática de $25 \mathrm{Kg}$, por 5 minutos. Os preparos que receberam cimento ionômero de vidro foram levemente umedecidos (grupos 1 a 4), não ocorrendo este evento nos que receberam cimento fosfato de zinco (grupo 5). Os grupos foram divididos desta forma: grupo 1 - cimentado em ambiente seco, com excesso de cimento intacto; grupo 2- cimentado em ambiente úmido e com excesso de cimento intacto; grupo 3- cimentado em ambiente úmido e remoção do excesso de cimento; grupo 4- cimentado em ambiente seco e excesso de cimento removido após 10 minutos, com aplicação de resina fotopolimerizável na interface; grupo 5 - cimentação em ambiente úmido com banda de cimento intacta. As amostras foram termocicladas em solução de fusina básica a $0,5 \%$, durante 500 ciclos, os dentes incluídos em resina epóxica, seccionados no sentido vestíbulolingual e avaliados quanto a erosão do cimento causada pelo estresse térmico, bem como para verificação do desajuste marginal provocado pela cimentação. Concluíram que houve pouca erosão nos grupos 1, 2 e 4 . O grupo 3 exibiu maior erosão do que os outros grupos. O grupo 5 apresentou maior erosão do que o grupo 
4, mas não significativamente diferente dos grupos 1 e 2 . Não houve diferença no grau de erosão quanto ao posicionamento da margem (esmalte ou cemento), ou em coroas com maior ou menor desajuste marginal.

HUNG et $\mathrm{al}^{47}$ (1993), examinaram os efeitos combinados do carregamento oclusal e da termociclagem simultânea no desajuste marginal de coroas provisórias. Para o estabelecimento das amostras, prepararam dois dentes pré-molares artificiais, sendo um com término cervical em ombro (grupo A) e o outro com término cervical em chanfrado (grupo B). Estes dentes foram duplicados e as réplicas obtidas em metal, estabelecendo-se 10 amostras para cada grupo. As coroas provisórias de metil metacrilato foram cimentadas nestas réplicas com óxido de zinco e eugenol, através de pressão digital por cinco minutos e colocadas em estufa a $37^{\circ} \mathrm{C}$ por uma semana. As amostras foram submetidas a ciclagem térmica (1700 ciclos) e ao carregamento oclusal através da fadiga de carga cíclica $(4,4 \mathrm{Kg})$, com frequência de $4 \mathrm{~Hz}$, totalizando 800 a 1000 impactos por dia. Concluíram que as diferenças entre as médias de desajuste marginal do grupo A $(85,9 \mu \mathrm{m})$ e do grupo B $(210,2 \mu \mathrm{m})$ foram estatisticamente significantes. Enfatizaram ainda que o controle do formato axial parece ser essencial para manutenção da saúde gengival, prevenção de cáries recorrentes ou redução da sensibilidade dentinária devida a penetração bacteriana na interface dente-restauração.

WHITE; KIPNIS ${ }^{123}$ (1993), realizaram um estudo para comparar o desajuste marginal em coroas totais metálicas, cimentadas com cimentos tradicionais e 
cimentos resinosos, antes e após a cimentação. Foram utilizados fosfato de zinco, ionômero de vidro, cimento resinoso com agente de união e Panavia Ex. Trinta e cinco pré- molares humanos extraídos, com altura de parede axial do preparo de $4 \mathrm{~mm}$ e conicidade 6 graus, foram moldados com silicona de polimerização por adição e os modelos obtidos em gesso tipo IV, sendo as fundições realizadas com liga de metal básico (Rexillium III, Jeneric Pentron). Todas as coroas foram cimentadas sob ação de uma carga vertical de $6 \mathrm{Kg}$ por 7 minutos. Dentre os valores obtidos nas duas situações, o cimento ionômero de vidro apresentou menor espessura de película $(25,6 \mu \mathrm{m})$, seguido do fosfato de zinco $(53 \mu \mathrm{m})$, policarboxilato $(72,1 \mu \mathrm{m})$ e cimento resinoso com agente de união $(227,9 \mu \mathrm{m})$. Atribuíram à grande discrepância observada entre os valores iniciais e finais no grupo do cimento resinoso devido ao aumento rápido da viscosidade antes da presa final, recomendando a aplicação de forças maiores no ato da cimentação ou alívio maior sobre os troquéis de gesso.

Novamente, WHITE; KIPNIS ${ }^{124}$ (1993), argumentaram que na literatura, o desajuste marginal vertical sempre foi considerado como padrão para verificação das discrepâncias entre o dente e restauração, e não o posicionamento tridimensional das coroas totais. Para isto, propuseram uma metodologia simples, onde os valores de assentamento para cada face eram computados, subtraídos da média geral e colocados na fórmula de desvio padrão. $\mathrm{O}$ valor do desvio padrão era interpretado como o posicionamento tridimensional: se o valor do desvio fosse zero, significava que não havia inclinação no assentamento das coroas, porque os valores de cada face eram coincidentes com a média obtida. Desta maneira, acreditavam que o 
posicionamento espacial das coroas poderia ser analisado pelo grau de afastamento das medidas de cada face em relação a média geral. Trinta e cinco pré-molares humanos foram preparados, sendo os padrões de cera obtidos em troquéis de gesso especial, e as fundições realizadas em liga de metal básico (Rexillium III). Foram verificados os valores de assentamento inicial sob pressão de $5 \mathrm{Kg}$, aplicação de um elastômero fluído (Fit-Checker, GC America), e cimentação definitiva. Os cimentos utilizados foram: ionômero de vidro, policarboxilato, fosfato de zinco, resinoso com agente de união e Panavia Ex. Concluíram que o posicionamento espacial das coroas fora afetado pela adaptação inicial, ajuste interno das paredes e cimentação; o ajuste com elastômero fluído levava a verticalização as coroas, ao passo que o processo de cimentação assentava as coroas em posição oblíqua; os cimentos resinosos proporcionavam maior inclinação às margens das coroas $(114,61 \mu \mathrm{m})$, em relação ao ionômero de vidro $(37,84 \mu \mathrm{m})$, fosfato de zinco $(12,95 \mu \mathrm{m})$ ou policarboxilato $(25,54 \mu \mathrm{m})$.

GUNDLER; LOCKOWANDT; ERHARDSON ${ }^{42}$ (1993), avaliaram a resistência à fadiga em coroas totais metálicas, cimentadas com fosfato de zinco, em função do grau de inclinação das paredes axiais e da rugosidade de superfície dentinária. Foram utilizados 50 dentes pré-molares e molares humanos, divididos da seguinte forma: 20 dentes com conicidade 20 graus (superfície lisa e rugosa), 20 dentes com conicidade 40 graus (superfície lisa e rugosa) e 10 dentes com conicidade 60 graus (superfície lisa). As amostras foram incluídas em blocos de resina acrílica e preparadas com pontas diamantadas em alta rotação e refrigeração constante. Os 
padrões de cera foram confeccionados diretamente sobre os preparos, sendo as fundições realizadas com uma liga de ouro (P-Dent). A superfície interna das coroas foi limpa com álcool e clorofórmio previamente a aplicação de cimento fosfato de zinco. Todas as fundições foram assentadas sob pressão digital e colocadas por 10 minutos sob uma carga de $5 \mathrm{Kg}$. A máquina de ensaios consistia de um dispositivo computadorizado que aplicada uma carga em cada corpo de prova através de uma série de células formadas por uma haste vertical e uma mola, acopladas a uma barra maior horizontal, impulsionada por uma bomba de ar comprimido. Este aparelho permitia que a carga fosse aplicada entre os valores de 50 a $700 \mathrm{~N}$, numa frequência de $2 \mathrm{~Hz}$, alternando a quantidade de estresse sobre as coroas, sendo os ciclos interrompidos quando o número aproximava-se de 1 milhão ou quando houvesse a descimentação das restaurações. Concluíram que: quanto a retenção (preparos com paredes lisas ou rugosas) e grau de inclinação, não foram encontradas diferenças para os grupos com conicidade de 20 e 40 graus. Com relação ao número de ciclos realizados até o momento da falha, nenhuma das coroas do grupo com conicidade 20 graus sofreu descimentação. Soltaram-se somente 14 coroas (sete com paredes lisas e sete com paredes rugosas) do grupo com conicidade 40 graus e todas as coroas do grupo com inclinação axial de 60 graus, sendo que o número de ciclos para tal efeito neste grupo foi menor do que nos grupos anteriores.

FERRARI et $\mathrm{al}^{28}$, em 1994, compararam a adaptação marginal de coroas totais "in vitro", analisando em microscopia eletrônica de varredura cortes longitudinais obtidos de corpos de prova incluídos em resina epóxica. Realizaram 
preparos em seis dentes molares humanos extraídos por problemas periodontais, com redução axial de $1,5 \mathrm{~mm}$ e oclusal de $2,0 \mathrm{~mm}$ e com término cervical em chanfrado. As coroas totais foram fundidas em ouro e cimentadas com fosfato de zinco (Lee Smith). Duas marcações foram feitas com brocas diamantadas nas faces vestibular e lingual, 2,0mm acima do término cervical, uma mais para mesial e outra mais para distal, a partir de um ponto médio de cada face. Em seguida foram realizadas moldagens com poliéter das faces lingual e vestibular de cada dente, sendo os moldes vazados com silicona de polimerização por condensação (Xantopren). Estas réplicas de silicone receberam uma camada de ouro para leitura em microscópio. As amostras incluídas em resina epóxica foram seccionadas no sentido vestíbulo-lingual com discos de diamante, em baixa velocidade e foram posicionadas de forma a recobrir a malha de leitura do microscópio. Ambas as medições foram realizadas por três examinadores e repetidas duas vezes. Os resultados mostraram que a variação intraobservador da acuidade de medição foi de $10 \mu \mathrm{m}$ para o método da réplica com material de moldagem e de $15 \mu \mathrm{m}$ para o método de cortes longitudinais. As médias de adaptação encontradas foram de $124,16 \mu \mathrm{m}$ (primeiro método) e de $129,79 \mu \mathrm{m}$ no método de cortes longitudinais.

WHITE; INGLES; KIPNIS ${ }^{127}$ (1994), dando continuidade aos seus estudos sobre a microinfiltração marginal, investigaram uma possível correlação entre a quantidade de penetração linear do corante e a abertura marginal em coroas totais metálicas. Trinta e cinco pré-molares humanos extraídos por razões ortodônticas foram utilizados, sendo a altura final dos preparos de $4 \mathrm{~mm}$ e o grau de convergência 
de $6^{\circ}$. A forma utilizada para a linha de término foi o chanfrado, sendo o mesmo colocado em esmalte nas margens vestibular e lingual e em dentina, nas margens mesial e distal. Os moldes foram confeccionados com silicona de polimerização por adição (Reprosil, Dentsply), vazados em gesso pedra melhorado (Die Keen) e as fundições foram realizadas com uma liga de metal básico (Rexillium III, Jeneric/Pentron). Todas as restaurações foram assentadas inicialmente sob pressão em seus respectivos preparos com auxílio de uma carga vertical de $5 \mathrm{Kg}$, sendo a abertura marginal inicial correspondente a distância vertical entre a margem do preparo e a porção mais apical da margem da restauração. Os dentes foram divididos em cinco grupos de agentes cimentantes: ionômero de vidro (Ketac-Cem, ESPE), policarboxilato (Durelon, ESPE), fosfato de zinco (Fleck's, Keystone), resina de micropartículas glicidilmetacrilato com agente de união à base de oxalato (Thin Film Cement e Tenure, Den-Mat), e resina de micropartículas com glicidilmetacrilato fosfato (Panavia Ex, Kuraray). Para a cimentação, todas as coroas foram assentadas e colocadas sob uma carga vertical de $5 \mathrm{Kg}$ durante sete minutos. Todas as amostras foram termocicladas a $37^{\circ} \mathrm{C}$ em água destilada (1500 ciclos) e tratadas com solução de nitrato de prata a $50 \%$. Dois cortes foram feitos no sentidos longitudinal, mesiodistal e vestíbulo-lingual através de marcas de referência previamente colocadas nas faces das restaurações. A penetração linear do nitrato de prata entre a margem do preparo e o agente cimentante ao longo da linha de cimentação foi visualizada e quantificada. As médias gerais de abertura marginal para os cimentos utilizados foram, em micrometros: ionômero de vidro-82,8; policarboxilato-141,6; fosfato de zinco-111,0; resina de micropartículas com agente de união à base de oxalato-335,0 e 
resina de micropartículas com glicidilmetacrilato fosfato-263,0. As médias gerais de penetração linear foram, em micrometros: ionômero de vidro-476,3 , policarboxilato829,0 , fosfato de zinco-1520, cimento resinoso com agente de união-144,1 e cimento resinoso metacrilato fosfato-352,1. Não foram encontrados valores estatisticamente significantes nos coeficientes de correlação para todos os agentes cimentantes estudados. Segundo os autores, a obtenção dos coeficientes de correlação negativos ou fracos (faixa de -0,12 a 0,31) puderam ser explicados pelas propriedades químicas dos agentes cimentantes, como solubilidade, contração marginal, tamanho de partícula e modo de falha. Dentro dos limites deste estudo, salientaram ainda que, embora na impossibilidade de se caracterizar a natureza desta relação, espaços marginais extremamente pequenos minimizariam o acúmulo de placa e a doença subsequente, já que a complexa interação entre a restauração, o agente cimentante e a estrutura dentária provavelmente estariam influenciando a microinfiltração.

WHITE et al $^{128}$ (1994), estudaram "in vivo" a infiltração marginal de coroas totais metálicas cimentadas com fosfato de zinco e ionômero de vidro híbrido resinoso. Quarenta dentes molares periodontalmente comprometidos, livres de cáries ou restaurações extensas, cujos antagonistas eram dentes naturais ou próteses fixas, receberam preparos com término cervical em chanfrado, sendo moldados com silicona de polimerização por adição e vazados em gesso tipo IV. As fundições foram obtidas com uma liga nobre (Deva 4, Degussa) e os agentes cimentantes utilizados foram: cimento fosfato de zinco e cimento ionomérico híbrido resinoso, 
com ou sem agente de união à dentina. Após ajuste das coroas, os cimentos foram pincelados no interior das mesmas e as coroas cimentadas com pressão digital, sendo que os pacientes ocluíam em bastão de laranjeira por 10 minutos. Os dentes foram extraídos após seis meses, colocados em solução de nitrato de prata por uma hora, incluídos em resina epóxica e seccionados nos sentidos vestíbulo-lingual e mésiodistal, para verificação da microinfiltração marginal. Concluíram que o cimento ionomérico híbrido resinoso, com ou sem agente de união à dentina, reduziu significativamente o grau de infiltração, se comparado ao cimento fosfato de zinco.

WHITE; FURUICHI; KYOMEN ${ }^{129}$ (1995), utilizaram 35 pré-molares humanos, extraídos por razões ortodônticas. Os preparos foram moldados com silicona de polimerização por adição, os troquéis obtidos em gesso tipo IV e as fundições realizadas com liga de metal básico (Rexilium III - Jeneric / Pentron). As coroas foram cimentadas com carga estática de $5 \mathrm{Kg}$ por sete minutos, sendo o desajuste marginal verificado antes e após a cimentação. Os cimentos utilizados foram: fosfato de zinco, policarboxilato, ionômero de vidro, cimento resinoso com agente de união e Panavia Ex. Após a termociclagem (1500 ciclos) e fixação das amostras com solução de nitrato de prata, estas foram embebidas em resina epóxica, seccionadas nos sentidos vestíbulo-lingual e mésio-distal para leitura da microinfiltração. Concluíram que o cimento resinoso com agente de união foi o que apresentou os menores valores de microinfiltração, seguido do ionômero de vidro, Panavia Ex, policarboxilato de zinco e fosfato de zinco. 
WHITE $^{131}$ (1995), procurando fazer uma revisão dos estudos clínicos e laboratoriais relacionando infiltração marginal, assentamento das coroas e espessura de película, enfatizou o uso da pesquisa básica, devido ao pouco entendimento que os pesquisadores possuíam sobre os mecanismos das falhas, características dos materiais e técnicas restauradoras. Argumentou ainda que seria necessário conhecer as propriedades físicas dos cimentos, como os limites de tensão e compressão, já que o ambiente bucal forneceria estresses que deveriam ser absorvidos e tolerados por essas restaurações. Citou ainda ser importante verificar o conteúdo de partículas de carga em agentes cimentantes adesivos e da aplicação de um agente de união à dentina que não aumente tanto a espessura de película como as discrepâncias marginais. Concluiu que o uso de dentes naturais forneceu melhores parâmetros para entender o comportamento dos agentes cimentantes, sendo que os valores de microinfiltração registrados para as coroas cimentadas com fosfato de zinco, em algumas situações, poderia ser devido a falha mecânica de interface e não à dissolução gradual deste cimento.

Neste mesmo ano, WHITE et $\mathrm{al}^{130}$, realizaram estudos "in vivo" para avaliação da adaptação marginal, em dentes periodontalmente abalados. Foram selecionados 24 pacientes, sendo um dente preparado em cada paciente. As moldagens foram realizadas com silicona de polimerização por adição, os troquéis obtidos em gesso tipo IV e as fundições realizadas em liga de ouro (Deva 4 Degussa). As coroas foram cimentadas com fosfato de zinco e cimento ionômero de vidro híbrido, com ou sem agente de união. Após seis meses, os dentes foram 
extraídos, embebidos em resina incolor e seccionados nos sentidos vestíbulo-lingual e mésio-distal. As discrepâncias foram verificadas traçando-se uma linha reta, da borda da coroa até a margem do preparo, tanto no sentido vertical como horizontal. Concluíram que as discrepâncias foram similares, sendo que o agente de união à dentina não aumentou os valores, e que as discrepâncias verticais observadas foram maiores do que as horizontais.

COLEMAN $^{11}$, em 1995, iniciou uma série de estudos, sendo possível avaliar a microinfiltração sem que as coroas cimentadas fossem cortadas ou destruídas. Para tanto, idealizou um microdispositivo de aço inoxidável do tipo tubo e parafuso, para ser acoplado ao padrão de cera nas faces vestibular e lingual. Após as fundições em liga de ouro tipo III, as coroas totais metálicas exibiam uma porta de acesso, pela qual filtros eram introduzidos. As portas eram seladas com parafuso e anel de borracha e as coroas colocadas em soluções que continham macromoléculas (dextran e lipopolissacarídeos) com sondas imunofluorescentes. Passado o tempo de imersão, os filtros eram retirados do interior das coroas e o exame de imunofluorescência realizado. Neste experimento piloto, concluíram que a microinfiltração das moléculas de lipopolissacarídeos ocorreu em 24 horas, sendo que esta recebeu escores maiores do que os filtros com dextran.

Segundo WISKOTT; NICHOLLS; BELSER ${ }^{134}$ (1995), em artigo que revisa os princípios e fornece indicações para a aplicação dos testes de fadiga na odontologia, as falhas observadas ao longo do tempo em próteses parciais fixas resultam não da aplicação de forças oclusais intensas, mas da frequência com que 
essas cargas são aplicadas. O processo de falha por fadiga pode ser visto como o resultado da progressão de fendas microscópicas que se desenvolvem em áreas de estresse ou na superfície do material. Num primeiro momento, estas fendas propagam-se para a superfície interna, enfraquecendo a composição estrutural. Quando a fenda atinge seu tamanho crítico, a direção de propagação passa a ser perpendicular a carga aplicada e finalmente em direção oblíqua, comprometendo toda a dimensão externa do objeto. A fundação estrutural corresponderia ao agente cimentante, onde a micromovimentação da coroa na interface culminaria na penetração de agentes bacterianos, responsáveis pelo processo carioso. Ainda, de acordo com os estudos de revisão que assinalam a frequência das cargas oclusais, seria necessário um mínimo de 1 milhão de ciclos de fadiga para simulação do tempo de vida útil de uma restauração metalocerâmica.

LIBMAN; NICHOLLS $^{65}$ (1995) verificaram se a extensão do preparo para coroas totais metálicas além da linha da junção cemento-esmalte, em combinação com a colocação de núcleos metálicos fundidos ou não, constituíam fatores significantes para o aumento do número de ciclos de fadiga até o momento da falha preliminar. Vinte e cinco incisivos centrais superiores humanos foram divididos em cinco grupos : grupo controle (coroas totais metálicas em dentes polpados), grupo 1 (extensão do preparo a $0,5 \mathrm{~mm}$ abaixo da junção cemento-esmalte), grupo 2 (extensão do preparo a 1,0mm da junção cemento-esmalte), grupo 3 (extensão a 1,5mm da junção cemento-esmalte) e grupo 4 (extensão a 2,0mm da junção cemento-esmalte). Nos grupos 1 a 4 foram utilizados núcleos metálicos fundidos. Todas as amostras 
foram incluídas em blocos de alumínio com resina autopolimerizável. As moldagens foram realizadas com poliéter e os troquéis obtidos em gesso tipo IV. Todas as coroas foram cimentadas com cimento fosfato de zinco sob carga de $10 \mathrm{Kg}$, por 10 minutos. Um extensômetro foi conectado na interface lingual dente-restauração para verificar a micromovimentação existente quando da aplicação da carga de fadiga. Todos os testes foram realizados sob carga de $4 \mathrm{Kg}$, a uma frequência de $1,2 \mathrm{~Hz}$, num ângulo de $135^{\circ}$, estando os corpos de prova imersos em água a temperatura ambiente. Concluíram que os grupos 1 (113 ciclos) e 2 (1140 ciclos) foram estatisticamente diferentes dos grupos 3 (71.651 ciclos) e 4 (60.045 ciclos). O grupo controle exibiu o maior número de ciclos até a falha preliminar (média de 91.000 ciclos). Os autores concluíram que é possível suportar maior número de ciclos até o momento da falha quando a extensão do preparo além da junção cemento-esmalte for maior ou igual a $1,5 \mathrm{~mm}$.

FAN ; NICHOLLS ; KOIS ${ }^{26}$ (1995), verificaram a quantidade de ciclos necessários para a descimentação de coroas totais metálicas, variando-se o material de reconstrução intracoronário (pino metálico pré-fabricado) e extra-coronário (amálgama e/ou pino dentinário). Foram utilizados 25 pré-molares humanos superiores recém extraídos, divididos da seguinte forma: grupo A (núcleo no conduto vestibular e amálgama), grupo B (núcleo no conduto lingual e amálgama), grupo C (núcleo nos condutos vestibular e lingual e amálgama), grupo D (dois pinos dentinários e amálgama) e grupo E (pino fundido no conduto lingual). Todas as amostras foram colocadas em blocos de resina, sendo os moldes dos preparos 
realizados com silicona de polimerização por adição e os troquéis obtidos em gesso tipo IV. As fundições foram realizadas com uma liga de ouro (MidGold 50) e as coroas cimentadas com carga de $10 \mathrm{Kg}$ por 10 minutos. O regime de ciclagem estabelecido foi de 250.000 ciclos com frequência de $1,2 \mathrm{~Hz}$ em água a temperatura ambiente, sob carga de 5,2Kg. Um extensômetro foi conectado para acusar a micromovimentação na interface dente-restauração. Quanto ao número de ciclos, concluíram que os grupos A e D falharam antes do limite pré-estabelecido (200.000 ciclos) e que os grupos B e E atingiram o limite estipulado sem falha preliminar.

WISKOTT; NICHOLLS; BELSER ${ }^{135}$ (1996), argumentaram que a resistência as forças laterais e não à retenção constitui fator determinante na estabilidade das coroas, devido aos vetores de força mastigatória agirem no sentido vestíbulo-lingual e vice- versa. Em geral, o deslocamento das coroas ocorre após um número significativo de ciclos que afeta a camada de cimento, sendo inofensivo tanto para o dente preparado quanto para a restauração. Em estudo experimental, verificaram a influência do aumento progressivo da conicidade dos troquéis ( entre 2,5 a $40^{\circ}$ ) em função da resistência as cargas de fadiga rotacional lateral, em coroas metálicas fundidas em NiCr-Mo. As coroas foram aleatoriamente cimentadas com cimento fosfato de zinco, ionômero de vidro, óxido de zinco e eugenol e cimento resinoso, sob carga de $5 \mathrm{Kg}$. Para cada tipo de cimento e grau de convergência foram realizadas trinta séries de testes, onde o regime de ciclagem foi de $16,7 \mathrm{~Hz}$ com 1 milhão de ciclos e os corpos de prova submetidos a temperatura de $37^{\circ} \mathrm{C}$ em água corrente. O teste só era interrompido se o corpo de prova acusasse fratura antes do 
número de ciclos proposto ou se ultrapasse o mesmo, sendo que a carga aplicada variava em função do número de ciclos atingidos. Concluíram que existia uma relação linear progressiva entre o grau de conicidade das paredes axiais e a resistência à fadiga lateral. Com relação aos agentes cimentantes, a ordem crescente de resistência verificada foi: cimento de óxido de zinco e eugenol, fosfato de zinco, ionômero de vidro e cimento resinoso.

Novamente, COLEMAN ${ }^{12}$, em 1996, dando continuidade a seus estudos, "in vitro", utilizou a mesma metodologia em 15 dentes molares humanos, onde as coroas foram assentadas com agente cimentante a base de óxido de zinco sem eugenol, por 10 minutos, estabelecendo como grupo controle as coroas apenas adaptadas aos respectivos preparos. As avaliações foram feitas nos períodos de 24 horas e após duas semanas. Concluiu que os valores de microinfiltração, nas coroas cimentadas com óxido de zinco, foram maiores para os lipopolissacarídeos (após duas semanas) do que para as moléculas de dextran. Argumentou ainda que este tipo de estudo poderia servir para avaliar: 1 - a extensão e o efeito dos agentes bacterianos e seus produtos na polpa sobre as restaurações fundidas; 2 a microflora predominante e seus subprodutos em diferentes estágios da inflamação pulpar, cicatrização e necrose; 3- qual tipo de produto (bactérias gram-positivas ou gram-negativas) seria mais importante; 4- materiais para construção de núcleos; 5- agentes cimentantes com ou sem antibióticos; 6- agentes de união à dentina e os tratamentos de superfície sem causar danos ao paciente. 
KIDD et al ${ }^{61}$ (1996), realizando estudos "in vivo", utilizaram oito molares e pré-molares, em função no ambiente bucal por 20 anos ou mais, tendo os mesmos recebido coroas totais metálicas cimentadas com fosfato de zinco. Todos os dentes foram extraídos por razões periodontais ou devido ao mal posicionamento que impedia a confecção de prótese parcial removível. Após a extração, os dentes foram limpos, os ápices das raízes selados e os espécimes imergidos em solução de fucsina básica a $0,05 \%$ por 24 horas. As amostras foram então embebidas em resina acrílica autopolimerizável e cada dente foi seccionado no sentido mésio-distal, sendo a avaliação da microinfiltração realizada em milímetros de penetração do corante, na interface dente-cimento. A espessura de película de cimento foi também verificada através de um microscópio, estando a média ao redor de $74 \mu \mathrm{m}$ para a superfície mesial e $47 \mu \mathrm{m}$ para a superfície distal. Concluíram que, embora certo grau de microinfiltração em alguns espécimens fosse evidente e nem todos possuíssem adaptação marginal satisfatória, isto não levou a falha das restaurações, já que o tempo médio de permanência em função foi de 20 anos.

BRÄNNSTRÖM ${ }^{7}$ (1996), recomendou alguns procedimentos que devem ser utilizados antes da cimentação de coroas totais, para redução do risco de resposta inflamatória no órgão pulpar: 1- adaptação adequada da coroa provisória, sem invasão dos tecidos periodontais, e cimentando a coroa definitiva o mais rápido possível; 2- a lama dentinária superfícial deveria ser removida e a dentina tratada com solução antibacteriana antes da colocação da coroa provisória; 3 - para diminuir a permeabilidade dentinária, aplicação de um liner que possa ser facilmente 
removido antes da cimentação final; 4- para assegurar adesão micromecânica ótima, a superfície dentinária deveria ser limpa, e a dentina mantida úmida até a cimentação e 5- a oclusão deveria ser cuidadosamente checada antes da cimentação da coroa.

HERSEK; CANAY ${ }^{45}$ (1996), argumentam que as soluções químicas utilizadas em testes de dissolução de agentes cimentantes são importantes para simular as condições do ambiente oral. $\mathrm{Na}$ medida em que o $\mathrm{pH}$ e as trocas de temperatura não são atingidas, o que é visto pode ser considerado como dissolução estática. Tentando solucionar este problema, avaliaram a microinfiltração marginal "in vivo", onde pequenos discos com agentes cimentantes foram colocados nas flanges linguais de pacientes portadores de próteses totais mandibulares. Foram utilizados três cimentos da mesma marca comercial (Shofu): fosfato de zinco, policarboxilato e ionômero de vidro . Todos os pacientes foram instruídos a escovar suas dentaduras, evitando o contato com as flanges linguais e o uso de agentes de limpeza. Após oito meses de uso, os dispositivos colocados no interior das dentaduras foram removidos e a quantificação da perda por dissolução realizada, bem como a espectroscopia para quantificação do elementos químicos constituintes dos cimentos. Concluíram que os cimentos de ionômero de vidro mostraram a menor taxa de dissolução. $O$ policarboxilato e o fosfato de zinco mostraram significativamente maior dissolução do que o cimento ionômero de vidro. A análise de espectroscopia revelou uma superfície com dissolução homogênea para todos os cimentos. 
MOJON et $\mathrm{al}^{75}$, em 1996, analisaram o efeito da presença de água, da saliva artificial e da saliva natural no processo de polimerização dos cimentos de fosfato de zinco (Flecks), ionômero de vidro (GC Fuji I) e resinoso (Panavia). Os cimentos foram misturados de acordo com as instruções do fabricante, colocados em um recipiente com $1,0 \mathrm{~mm}$ de espessura e $5,0 \mathrm{~mm}$ de diâmetro e prensados entre duas placas de vidro para eliminar os excessos. Em seguida foram colocados em estufa a $37^{\circ} \mathrm{C}$. Os corpos de prova foram divididos em dois grandes grupos, onde um deles entrava em contato com a água e o outro não. O primeiro foi subdividido em quatro, diferenciando-se o mome nto em que ocorreu o contato: 5, 10, 15 e 20 minutos após a mistura. Após contato por dez minutos com água e saliva, os corpos de prova foram colocados em 100\% de umidade (ar saturado com água) ou imersos em água deionizada e destilada. A dureza dos cimentos foi medida a cada 30 minutos através de equipamento especial (Kentron Micro Hardness Tester) com ponta para dureza Knoop de 100 gramas. A leitura foi realizada cinco vezes para cada corpo de prova. Os resultados obtidos demonstraram que a água apresentou um efeito mais negativo sobre os cimentos do que a saliva artificial ou natural. O cimento ionômero de vidro apresentou maior dureza $(48,3 \pm 3,8 \mathrm{KHN})$ do que o fosfato de zinco $(38,9 \pm 7,5$ KHN) ou resinoso $(35,4 \pm 10,2 \mathrm{KHN})$, após uma semana de armazenamento, em condições de $100 \%$ de umidade. Quando imersos em água, a dureza do fosfato de zinco e do cimento de ionômero de vidro diminuiu quase a metade $(26,2 \pm 2,7$ e 16,9 $\pm 2,5 \mathrm{KHN}$, respectivamente). A contaminação nos primeiros cinco minutos após a mistura diminuiu a dureza dos cimentos de fosfato de zinco e ionômero de vidro para $0,39 \pm 0,1 \mathrm{KHN}$ e $0,52 \pm 0,12 \mathrm{KHN}$, respectivamente, mas apresentou pouco efeito 
no cimento resinoso. Concluíram que, clinicamente, o cimento de ionômero de vidro deve ser protegido da ação de água e saliva nos primeiros 15 minutos após a mistura.

WISKOTT; NICHOLLS; BELSER ${ }^{136}$ (1997), dando continuidade a metodologia empregada anteriormente, verificaram a influência do diâmetro e da altura do preparo na resistência de cargas dinâmicas hterais. A altura do preparo variou de 1 a $7 \mathrm{~mm}$ em incrementos de $1 \mathrm{~mm}$, sendo da mesma maneira para o diâmetro (de 3 a 8mm). O número de ciclos foi de 1 milhão, sendo a frequência utilizada de $16,7 \mathrm{~Hz}$. Os cimentos testados foram : óxido de zinco e eugenol, fosfato de zinco, cimento ionômero de vidro e resinoso. Concluíram que: existiu uma relação linear progressiva tanto para a altura como para o diâmetro em relação à resistência as cargas laterais e que em relação aos cimentos, a variação foi observada na seguinte ordem crescente (óxido de zinco e eugenol, fosfato de zinco, ionômero de vidro e cimento resinoso).

CATOVIC et al $^{9}$ (1997), realizou estudo com testes de fadiga "in vitro" em dentes pré-molares humanos. Cento e vinte amostras foram escolhidas e divididas em três grupos, com 40 dentes cada, da seguinte forma: pré-molares intactos, com planificação da superfície oclusal e manutenção dos contornos das cúspides vestibulares e linguais. Dentro de cada grupo foram empregadas forças de carregamento de 400 a $1400 \mathrm{~N}$, sem frequência especificada. Observaram que existiu uma correlação forte e negativa entre o grau de força aplicada e o número de ciclos 
necessários para a fratura, dentro de cada grupo. O maior número de ciclos até a fratura foi registrado para o grupo de dentes intactos.

LYONS; RODDA; HOOD ${ }^{67}$, em 1997, compararam a microinfiltração de coroas totais cimentadas com cimento de fosfato de zinco (S.S. White), ionômero de vidro (Vitremer) e cimento resinoso (Panavia 21). Utilizaram 60 pré-molares humanos que foram divididos em três grupos, sendo os preparos feitos com inclinação de 6 graus nas paredes axiais e linha do término em ombro na junção amelocementária. Após moldagem com silicona de polimerização por adição, os padrões de cera foram construídos sobre troquéis de gesso tipo $\mathrm{V}$, e as fundições realizadas com uma liga com alto conteúdo de paládio (Spartan Plus-Williams). Todas as coroas foram cimentadas sob ação de uma carga estática de 2,0Kg durante 15 minutos. Os corpos foram então armazenados em solução de cloreto de sódio a $0,9 \%$ por sete dias a $37^{\circ} \mathrm{C}$. Para o teste de microinfiltração foi adaptada uma cânula metálica no interior dos condutos radiculares, conectada a uma câmara de pressão, onde mediante a abertura da válvula, gás nitrogênio era bombeado para o interior dos condutos radiculares, a uma pressão constante de 3 atmosferas, perfazendo um total de 15 ciclos de compressão para cada amostra. Este aparato foi montado para estudar os fenômenos correlacionados com as mudanças de pressão do ambiente, relatado por aviadores e mergulhadores. Após a ciclagem, foi verificada também a resistência à remoção de cada coroa pelo teste de tração. Dentro dos limites deste estudo, os resultados mostraram infiltração marginal em todos os corpos de prova 
cimentados com cimento fosfato de zinco, em sete dos dez cimentados com ionômero de vidro e nenhuma infiltração no grupo do cimento resinoso.

YOSHIDA; TANAGAWA; ATSUTA ${ }^{141}$ (1998), realizaram um estudo "in vitro" com o objetivo de comparar a solubilidade de três cimentos resinosos utilizados com frequência pelos cirurgiões-dentistas: All-Bond C\&B (Bisco), Panavia 21 (Kuraray), e Super-Bond C\&B (Sun-Medical), com três cimentos convencionais, ou seja, fosfato de zinco (Elite Cement 100, GC), policarboxilato (HY-Bond Carbo-Plus Cement - Shofu) e ionômero de vidro (Fuji I , GC). Os cimentos foram espatulados com temperatura e umidade controlada, em discos de $15 \mathrm{~mm}$ de diâmetro e $0,6 \mathrm{~mm}$ de espessura, e armazenados por 30 dias em água destilada e solução de ácido lático com pH 4,0. A variação das massas fornecia a medida de dissolução. Os autores concluíram que: o cimento fosfato de zinco, ionômero de vidro, All Bond e Panavia 21 foram mais solúveis na solução de ácido do que em água destilada; os cimentos resinosos foram marcadamente menos solúveis que os cimentos convencionais quando colocados em solução de ácido lático fresco $(0,001 \mathrm{~mol} / \mathrm{L})$ em $\mathrm{pH}$ 4,0 a cada 24 horas, no período de 30 dias; o grau de solubilidade aumentou de maneira linear com o passar do tempo e que as restaurações cimentadas com o cimento resinoso podem ser capazes de resistir por um tempo maior em uso clínico, quando comparadas aos agentes cimentantes convencionais. 
ETTINGER et $\mathrm{al}^{25}$ (1998), avaliaram a microinfiltração marginal em dentes cimentados com coroas de aço inoxidável. Sessenta molares foram extraídos de pacientes com idade ente 50 e 70 anos, por motivo de doença periodontal. Após duas semanas de armazenamento em solução de formalina a $10 \%$, os dentes foram preparados e coroas de aço inoxidável (Unitek 3M) foram adaptadas aos preparos, sendo que a margem das coroas permaneceu 1 a $2 \mathrm{~mm}$ acima da junção cementoesmalte. Canais para o escape do cimento foram colocados nas paredes vestibular e lingual. As amostras foram divididas em quatro grupos com os seguintes agentes cimentantes: fosfato de zinco (Fleck's), ionômero de vidro (Ketac-Cem), cimento resinoso autopolimerizável (Panavia Ex) e compósito resinoso autopolimerizável (All-Bond C\&B Cement). As coroas foram mantidas em posição sob pressão digital até a presa dos cimentos. Todos os dentes foram termociclados em água nas temperaturas de 5 e $55^{\circ} \mathrm{C}$, em regime de 300 ciclos. Três dentes de cada grupo foram submetidos aos seguintes tratamentos: 1- termociclagem e corante (fucsina ácida a $0,5 \%$ por 24 horas); 2 - termociclagem, carregamento oclusal ( $15 \mathrm{Kg}, 50.000$ ciclos) e corante; 3- termociclagem, carregamento oclusal, termociclagem e corante; 4- o mesmo do 3 mais o teste com ácido. Os autores concluíram que as coroas cimentadas com ionômero de vidro mostraram maior extensão de penetração do corante e as deficiências de interface não constituíram um fator para aumento da penetração do corante.

FREEMAN et al ${ }^{31}$ (1998), avaliaram o número de ciclos de fadiga necessários para indução da falha preliminar em coroas totais metálicas, 
confeccionadas em dentes tratados endodonticamente e restaurados com pinos fundidos e pré-fabricados. Foram utilizados trinta e seis incisivos centrais superiores, divididos da seguinte forma: grupo 1 (10 dentes com pino pré-fabricado Parapost e reconstrução coronária com resina composta), grupo 2 (10 dentes com pino préfabricado Flexi-Post e reconstrução coronária com resina composta) e grupo 3 (10 dentes com pino metálico fundido). Em cada grupo foram colocadas duas amostras que serviram como controle, sendo as mesmas submetidas apenas aos testes de microinfiltração. Todas as amostras receberam coroas totais metálicas fundidas com liga de $\mathrm{Pd}-\mathrm{Ag}$, sendo os pinos e as coroas cimentadas com fosfato de zinco, sob pressão digital por 10 minutos. Um extensômetro foi colocado na interface lingual dente-coroa para verificar a micromovimentação. O número de ciclos mecânicos foi realizado até indução da falha preliminar, sendo a frequência de $1,2 \mathrm{~Hz}$ e carga de 3,5Kg. Após a falha preliminar, 100.000 ciclos adicionais foram aplicados com carga de $1 \mathrm{Kg}$. Após análise visual, 26 amostras que não mostravam sinais de fratura foram selecionadas para os testes de microinfiltração. Os dentes foram então imersos em solução de fucsina básica a $0,5 \%$ por 24 horas, sendo posteriormente incluídos em resina acrílica incolor e seccionados no sentido mésio-distal, paralelamente ao plano vestíbulo-lingual. Os escores de penetração foram: 0 - sem penetração; 1- penetração do corante na interface restauração-cimento ou na interface dente-cimento; 2penetração na interface restauração-cimento ou dente-cimento, sem extensão para o interior do núcleo; 3- extensão do corante para o interior do canal; 4 extensão do corante para além do limite apical do canal. Concluíram que, com relação ao número de ciclos empregados, não houve diferenças estatisticamente significantes para os 
três grupos. O grau de infiltração foi menor no grupo controle do que no grupo experimental, não havendo diferenças com relação aos três sistemas empregados.

JUNGE et $\mathrm{a}^{58}$ (1998), em estudo semelhante, utilizaram incisivos centrais superiores restaurados com pinos metálicos fundidos, recobertos por coroas totais metálicas, em função da variação do agente cimentante. Quinze dentes recémextraídos foram selecionados e preparados, sendo os moldes obtidos com silicona de polimerização por adição e os tróqueis confeccionados com gesso tipo IV. Os núcleos foram obtidos pela moldagem direta dos condutos com auxílio de pinos plásticos e resina Duralay, incluídos, fundidos em liga de ouro tipo III e cimentados com cimento fosfato de zinco. Todas as coroas foram fundidas com liga de ouro tipo III, assentadas sob pressão digital por 10 minutos e cimentadas com fosfato de zinco (grupo 1), ionômero de vidro (grupo 2), e cimento resinoso (grupo 3). Um extensômetro foi conectado na interface dente-restauração para registro da micromovimentação. A carga empregada na ciclagem mecânica foi de $1,5 \mathrm{Kg}$, com frequência de $1,2 \mathrm{~Hz}$, estando as amostras imersas em água a temperatura ambiente, até o momento da falha preliminar. Os dentes foram seccionados no sentido vestíbulo-lingual para inspeção visual da linha de fratura do cimento. Concluíram que as coroas cimentadas com cimento resinoso propiciaram maior número de ciclos até o momento da falha preliminar do que as coroas cimentadas com fosfato ou ionômero de vidro; não houve diferença estatisticamente significante entre o número de ciclos para as coroas cimentadas com fosfato de zinco ou ionômero de vidro; 
todas as coroas cimentadas com cimento resinoso ultrapassaram o regime de 80.000 ciclos sem fratura da camada de cimento.

TUNG; COLEMAN ${ }^{110}$ (1998), utilizando a metodologia já descrita por COLEMAN $^{11,12}(1995,1996)$, avaliaram a microinfiltração marginal em coroas totais metálicas cimentadas com fosfato de zinco, ionômero de vidro e cimento resinoso. Trinta dentes molares humanos foram utilizados, sendo os preparos moldados com silicona de polimerização por adição e as fundições realizadas com liga de ouro tipo III. As amostras foram divididas em três grupos: grupo 1- aplicação de duas camadas de verniz copal e cimentação com fosfato de zinco; grupo 2- condicionamento com ácido poliacrílico e cimentação com ionômero de vidro, sendo aplicado em seguida verniz protetor; grupo 3- cimentação com cimento resinoso. Todas as coroas foram assentadas com pressão digital por 10 minutos. Para o teste de microinfiltração, filtros foram colocados nos receptáculos laterais de acesso e as amostras embebidas em solução contendo macromoléculas de dextran e lipopolissacarídeos com sondas imunofluorescentes. As verificações foram realizadas após duas semanas, 1, 2, 3, 4, 5 e 6 meses, não sendo detectada microinfiltração em qualquer dos três tipos de agentes cimentantes utilizados, dentro dos limites deste estudo.

PILO; CARDASH ${ }^{92}$ (1998), cientes da quantidade de estudos "in vivo" ser pequena, estudaram o desajuste marginal de coroas totais metálicas cimentadas com fosfato de zinco em noventa e sete dentes comprometidos periodontalmente (48 anteriores, 22 pré-molares e 27 molares) foram utilizados. Todas os dentes após 
extração cuidadosa foram embebidas em resina acrílica incolor e seccionadas no sentido vestíbulo-lingual. As médias gerais de desajuste marginal observadas foram: vestibular $(116 \mu \mathrm{m})$, lingual $(109 \mu \mathrm{m})$ e oclusal $(302 \mu \mathrm{m})$, sendo o desajuste obtido na superfície oclusal dos molares $(369 \mu \mathrm{m})$ mais significante do que nos pré-molares $(219 \mu \mathrm{m})$. Verificaram existir correlação significante $(\mathrm{r}=0,91)$ entre a espessura de cimento e as pontas de cúspide ou fossa oclusal

JUDGE; WILSON ${ }^{57}$ (1999), investigaram "in vitro" efeito de forças vibratórias no escoamento do cimento e assentamento de coroas cimentadas em troquéis de aço inoxidável. As coroas foram cimentados sob vibração por 1 e 60 segundos. Os cimentos utilizados foram: policarboxilato (Durelon), ionômero de vidro (Ketac Cem), Panavia 21, fosfato de zinco (Phosphacap) e Vitremer, sob cargas pré-determinadas escolhidas pelos autores, que refletiriam as condições clínicas $(0,25 ; 1,27$ e $2,55 \mathrm{Kg}$, com ou sem introdução do aparelho de vibração. Verificaram que o aumento de 1,27 para $2,55 \mathrm{Kg}$ não proporcionou melhor assentamento das coroas, ao passo que a introdução de forças oscilatórias de baixa frequência proporcionaram melhora no escoamento do cimento e no as sentamento das coroas.

Novamente, COLEMAN; MOSES; RICKERBY ${ }^{13}$ (2001), utilizando a metodologia já descrita, decidiram estender o tempo de avaliação da microinfiltração para dois anos, em coroas totais fundidas em liga de ouro e cimentadas com fosfato de zinco, ionômero de vidro e agente resinoso. Novamente verificaram que não houve diferença nos resultados de microinfiltração para as macromoléculas utilizadas 
(lipolissacarídeos e dextran), ao nível das portas de acesso. Como não foi verificada infiltração, os autores argumentaram que as moléculas poderiam ter atingido os túbulos dentinários e não chegado as áreas de posicionamento dos filtros. Comprometeram-se ainda a desenvolver novos estudos de microfluorescência, com maior capacidade de detecção destas mo léculas.

LINDQUIST; CONNOLLY ${ }^{66}$ (2001), realizaram um estudo "in vitro" para verificar a microinfiltração em coroas totais metálicas cimentadas com fosfato de zinco e ionômero de vidro reforçado com resina, sobre condições ideais e contaminadas. Cento e quarenta dentes molares humanos foram extraídos e receberam preparos para coroas totais, em coroas com estrutura coronária em dentina, amálgama e resina composta, sendo confeccionadas cavidades classe II nas superfícies mesiais de cada dente. Foram formados sete grupos: 1) amálgama e verniz cavitário, 2) amálgama e agente de união, 3) resina composta e agente de união, sendo os materiais de reconstrução coronária colocados sob condições secas e úmidas. O sétimo grupo consistia de preparos com cavidades classe II sem material de reconstrução. Após moldagem com silicona de polimerização por adição (Extrude, Kerr) e obtenção dos padrões de cera em troquéis de gesso tipo IV , as fundições foram realizadas com liga de ouro tipo III. Todas as coroas foram cimentadas sob pressão digital, constituindo quatro grupos onde os agentes cimentantes eram utilizados sob condições ideais e contaminadas. As amostras eram então termocicladas $\left(150\right.$ ciclos, temperatura variando de 5 a $\left.55^{\circ} \mathrm{C}\right)$ e imersas em solução de eritrosina B por 24 horas, incluídas em resina e seccionadas no sentido 
mésio-distal. Dentro dos limites deste estudo, os autores concluíram que a menor infiltração foi verificada nas coroas cimentadas com ionômero de vidro reforçado por resina, para todos os materiais de reconstrução coronária; o menor grau de microinfiltração foi verificado em reconstruções com amálgama de prata ou resina composta, utilizando-se o agente de união.

MITCHELL; PINTADO; DOUGLAS ${ }^{74}$ (2001), observaram que todos os testes utilizados em laboratório para avaliação das discrepâncias marginais acabavam por destruir os corpos de prova, dando margem a artefatos de técnica ou interpretações arbitrárias. Desta forma, propuseram um método onde a continuidade da interface dente-restauração foi avaliada através de um perfilômetro. Realizaram um estudo em 48 pré-molares humanos, onde o tipo de término cervical (chanfrado ou ombro), bem como o tipo de coroa (total metálica, metalocerâmica, ou coroa total de porcelana) eram analisadas somente em função do assentamento das restaurações em seus respectivos preparos. O perfilômetro registrava os desajustes em toda a circunferência do dente, sem remover material da margem ou necessidade de secção dos espécimes. Concluíram que para cada espécime houve variação considerável de perfil para perfil, com mudanças rápidas de sobrextensão para sobextensão; poucos perfis atingiram perfeita adaptação vertical ou marginal; os melhores resultados foram verificados para o grupo das coroas totais de porcelana com término cervical dos preparos em ombro. 
PROPOSIÇÃO 
PROPOSIÇÃO 58

\section{3 - PROPOSIÇÃO}

Este trabalho teve como objetivo verificar as seguintes hipóteses:

3.1 - existência de uma correlação positiva e forte entre a discrepância de assentamento, abertura marginal e o grau de infiltração em coroas metalocerâmicas cimentadas com três tipos de agentes cimentantes: fosfato de zinco, ionômero de vidro e cimento resinoso;

3.2 - a influência da ciclagem dinâmica na qualidade estrutural do cimento e infiltração marginal 
MATERIAL E MÉTODOS 


\section{MATERIAL E MÉTODOS}

Foram utilizados trinta dentes pré-molares superiores humanos, hígidos ou associados a pequenas lesões cariosas e que apresentavam dimensões médias semelhantes aos estudos de GALAN JÚNIOR ${ }^{33}(\mathrm{VL}=8,655 \pm 0,875 \mathrm{~mm} ; \mathrm{MD}=$ $6,047 \pm 0,962 \mathrm{~mm})$. Após limpos, os dentes foram armazenados em solução de formalina neutra. As cáries foram removidas e preenchidas com resina composta, e os dentes armazenados em soro fisiológico ${ }^{20}$, contendo Timol a $0,1 \%$.

\subsection{Preparo dos corpos de prova}

Para homogeneização dos grupos, cada dente teve suas dimensões vestíbulo-lingual e mésio-distal determinadas com um paquímetro digital com resolução de 0,1mm (Mitutoyo Corporation, Japan). A variação destas dimensões resultou na seleção de dentes com VL máxima de 10,50 e mínima de 7,00mm, e no sentido MD com medida máxima de 7,70 e mínima de 6,0mm. Os intervalos entre as extensões máximas e mínimas de cada face (VL e MD) foram divididos em 3 grupos iguais e denominados de Pequeno (P), Médio (M) e Grande (G), sendo que no sentido VL as medidas P ficaram entre 7,0 e $8,90 \mathrm{~mm}$, as $\mathrm{M}$ entre 9,0 e $9,55 \mathrm{~mm}$ e as $\mathrm{G}$ entre 9,65 e 10,50mm. No sentido $\mathrm{MD}$, as medidas $\mathrm{P}$ estavam entre 6,0 e 6,55mm, as $\mathrm{M}$ entre 6,65 e 7,5mm e as $\mathrm{G}$ entre 7,55 e 7,70mm. Assim , os dentes foram classificados de acordo com a combinação das medidas (VL/MD), resultando em 
dentes $\mathrm{G} / \mathrm{G}, \mathrm{G} / \mathrm{M}, \mathrm{G} / \mathrm{P}, \mathrm{M} / \mathrm{M}, \mathrm{M} / \mathrm{P}, \mathrm{P} / \mathrm{M}$ e P/P, que ficaram distribuídos conforme a tabela 1.

Tabela 1 - Distribuição numérica dos dentes de acordo com sua medidas

\begin{tabular}{llll}
\hline & & \multicolumn{2}{c}{ MD } \\
\cline { 2 - 4 } VL & $\mathrm{P}$ & $\mathrm{M}$ & $\mathrm{G}$ \\
$\mathrm{P}$ & 3 & 4 & 3 \\
$\mathrm{M}$ & 3 & 4 & 3 \\
$\mathrm{G}$ & 3 & 4 & 3 \\
\hline $\mathrm{VL}=$ listância vestíbulo-lingual; MD $=$ distanncia mesio-distal
\end{tabular}

VL =distância vestíbulo- lingual; MD =distância mésio-distal

Os 30 dentes foram então, divididos em três grupos de 10, em função dos agentes cimentantes (fosfato de zinco, ionômero de vidro e cimento resinoso), procurando fazer uma distribuição mais uniforme dos dentes nos diferentes grupos, de acordo com suas dimensões e sua classificação mencionada anteriormente, tentando minimizar a influência dos diferentes tamanhos dos dentes nos resultados finais. (Tabelas 2 e 16) 
Tabela 2 - Distribuição das amostras nos diferentes grupos, de acordo com a classificação adotada

\begin{tabular}{lccc}
\hline \multicolumn{1}{c}{ Material } & \multicolumn{3}{c}{ Dimensões VL e MD } \\
\cline { 2 - 4 } & P-P & M-M & G-G \\
Fosfato de zinco & $1,3,7$ & $4,5,6,10$ & $2,14,15$ \\
Ionômero de vidro & $8,9,11$ & $12,18,19,20$ & $17,21,22$ \\
Cimento resinoso & $13,16,28$ & $25,26,27,29$ & $23,24,30$ \\
\hline
\end{tabular}

Em seguida, os dentes foram incluídos com gesso tipo IV (Vel-Mix, Kerr) nos centros de cilindros de PVC (Tigre do Brasil) de 10,90mm de diâmetro por 30mm de altura, com o longo eixo perpendicular à base do cilindro. A linha da junção amelocementária foi posicionada $4 \mathrm{~mm}$ aquém do topo do cilindro. Todas as amostras foram armazenadas em soro fisiológico e timol a $4^{\circ} \mathrm{C}$.

\subsection{Preparo dos dentes}

Os dentes foram preparados para coroas metalocerâmicas, seguindo-se a técnica preconizada por PEGORARO et $\mathrm{al}^{88}$, sendo que para o desgaste do término cervical, foi utilizada uma lupa frontal com quatro vezes de aumento (Bio-Art, Equipamentos Odontológicos, São Carlos, SP), para melhor controlar o desgaste desta região. (figura 1) 


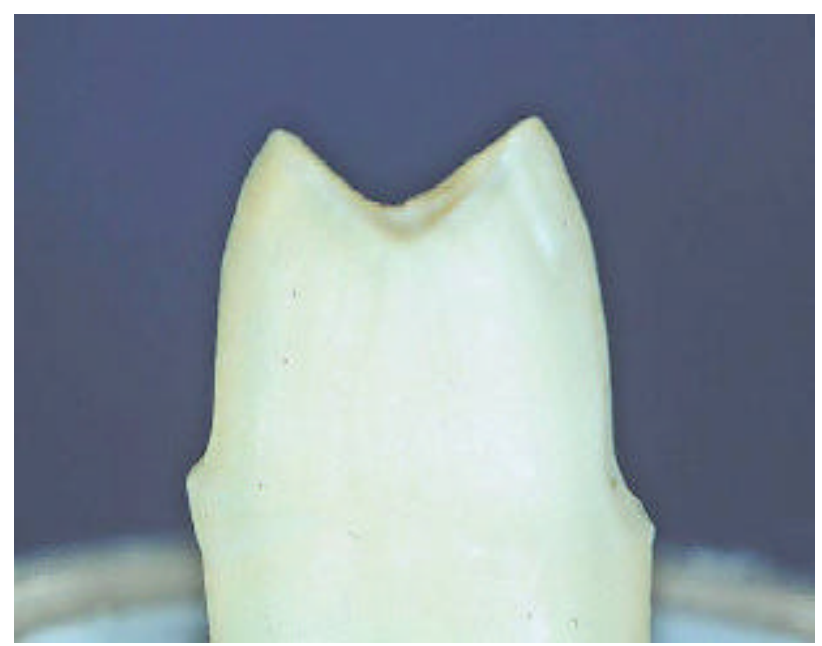

Figura 1 - Dente preparado

\subsection{Moldagens e obtenção dos troquéis}

Todos os dentes foram moldados com silicona de polimerização por adição (Express, 3M do Brasil Ltda, Sumaré, SP), usando-se moldeiras individuais confeccionadas com cilindros de PVC de 10,90mm de diâmetro por $15 \mathrm{~mm}$ de altura, tendo uma de suas extremidades fechada com cera utilidade (Epoxiglass, Epoxiglass Ind. e Com. de Produtos Químicos Ltda, Diadema, SP). Para isso, quantidades iguais de pasta densa foram manipuladas e colocadas no interior da moldeira, que foi assentada sobre o preparo, até que a borda da moldeira tocasse o topo do cilindro. A moldeira foi retirada e um alívio interno com lâmina de bisturi realizado sobre as superfícies retentivas do molde. Em seguida, a pasta fluída foi dispensada sobre as superfícies do preparo e no interior do molde, com auxílio de uma ponta dispensadora acoplada a uma pistola e a moldeira levada em posição. Após a presa do material, a leitura de possíveis irregularidades nas superfícies dos moldes foi realizada com lupa de quatro aumentos e os moldes considerados inadequados foram 
descartados. Seguindo as recomendações do fabricante, aguardava-se duas horas para o vazamento, que foi realizado com gesso extra-duro tipo IV (Vel-Mix, Kerr). Os troquéis obtidos foram rigorosamente inspecionados, sendo descartadas as réplicas consideradas inadequadas.

\section{4- Confecção das coroas totais}

Sobre cada troquel foi confeccionado um padrão de cera, com dimensões semelhantes a uma infra-estrutura para coroa metalocerâmica, tendo sua superfície oclusal plana. A linha do término cervical foi avaliada com lupa frontal de quatro aumentos. Os padrões de cera foram incluídos em revestimento aglutinado por fosfato (Talladium Inc, California, EUA) e fundidos com uma liga a base de níquelcromo (Verabond II , AALBA Dent Inc., Califórnia, EUA), seguindo-se as instruções dos fabricantes.

\subsection{Adaptação das coroas totais}

Após a desinclusão, as coroas foram limpas com jatos de esfera de vidro e após a remoção dos condutos de alimentação, foram adaptadas nos respectivos troquéis e em seguida nos dentes preparados. Para detectar áreas ou pontos de atrito que impediriam o assentamento das coroas nos respectivos preparos, empregou-se líquido evidenciador de contato (Accufilm IV, Farmingdale, New Jersey, EUA), aplicado com auxílio de um pincel pelo de marta nº 00 (Tigre do Brasil, Osasco, SP) 
nas paredes internas das fundições. As áreas de atrito e nódulos de fundição eram removidas com broca de aço esférica $\mathrm{n}^{\circ} 02$ (KG-Sorensen, Barueri, SP), em alta rotação sob refrigeração constante. Este procedimento foi repetido até que uma película uniforme de evidenciador fosse observada. A verificação da adaptação foi realizada com auxílio de uma sonda exploradora n05 (S.S. White, RJ) e com lupa frontal de quatro aumentos.

\subsection{Medida inicial da discrepância de assentamento}

Para as mensurações da discrepância inicial de assentamento, foram feitas perfurações com uma broca de aço esférica $\mathrm{n}^{\circ} 2$ nas faces vestibular, lingual, mesial e distal da superfície radicular, cerca de $1,5 \mathrm{~mm}$ abaixo do término cervical. Essas perfurações foram preenchidas com resina acrílica autopolimerizável (Duralay Reliance Dental Mfg. Co., Chicago, EUA) que recebeu acabamento com borracha abrasiva (Viking- KG Sorensen Ind. e Com. Ltda, Barueri, São Paulo), tomando-se o cuidado de deixar suas bordas bem definidas. Na mesma direção destas marcas e, aproximadamente $1,5 \mathrm{~mm}$ acima da borda cervical das coroas, também foram feitas perfurações para servirem como pontos de referência para as mensurações.

Estas marcações foram realizadas em função da dificuldade de se visualizar nitidamente as margens da coroa e a linha de término cervical do preparo como pontos de referência para a mensuração da linha de cimento, devido a presença do cimento nesta região após a cimentação. (figura 2) 

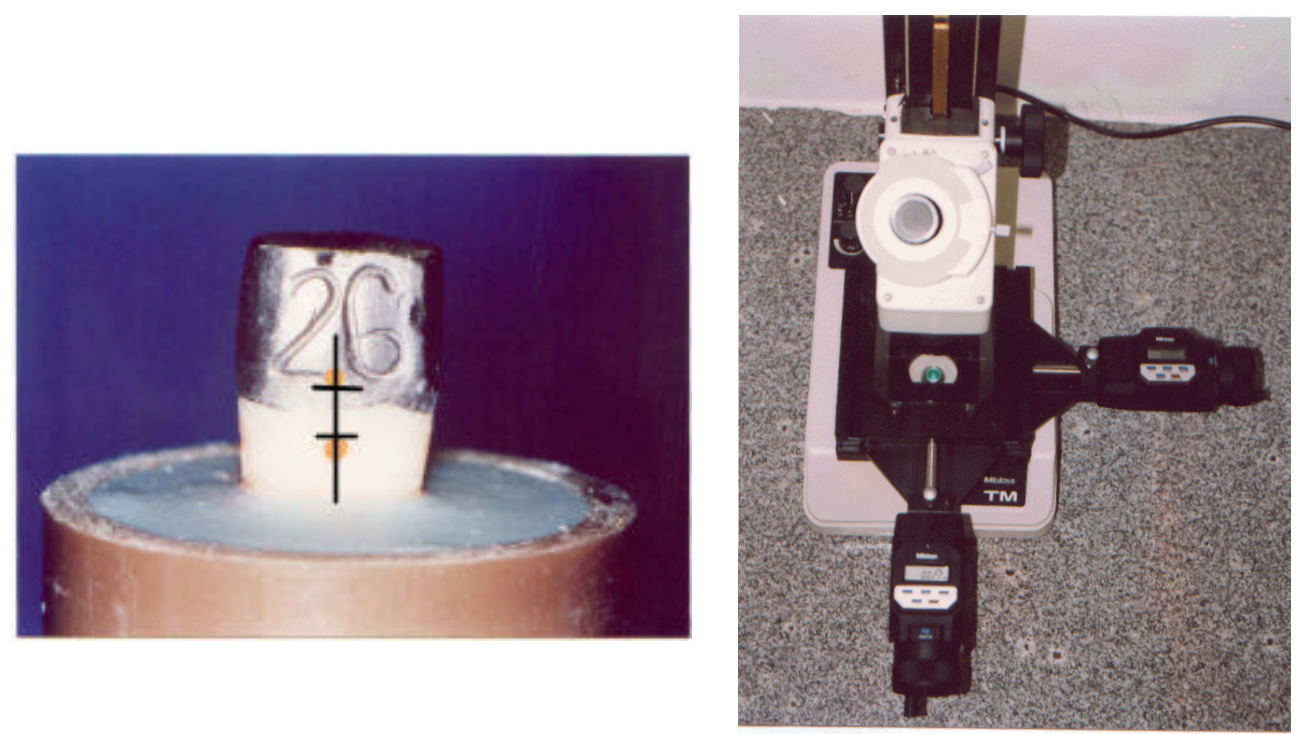

Figura 2 - Esquerda $($ a) $=$ Marcações realizadas na coroa e dente preparado. Direita (b) = microscópio utilizado para leitura de discrepância de assentamento

Após o assentamento das coroas nos respectivos dentes preparados com carga estática de $5 \mathrm{Kg}$, a linha vertical presente no retículo do microscópio foi conduzida de forma a coincidir exatamente na parte central de ambas as esferas. Em seguida, a linha horizontal foi direcionada para tangenciar a extremidade inferior da esfera correspondente à perfuração feita na coroa, obtendo-se um valor numérico em micrometros. Depois, esta linha foi guiada para tangenciar a extremidade superior da esfera presente na raiz do dente preenchida com resina Duralay, e um outro valor numérico foi obtido e anotado.

Para minimizar a possibilidade de erros neste tipo de medição, as leituras foram repetidas três vezes para cada face, totalizando 12 leituras. Os dois valores anotados foram subtraídos após as medidas terem sido realizadas, e depois foi obtida uma medida média para cada face e para cada dente. 


\subsection{Cimentação e medida final da discrepância de assentamento}

Previamente a cimentação, todos os preparos foram limpos com pedrapomes de granulação fina e as coroas receberam jateamento interno com partículas de óxido de alumínio $50 \mu \mathrm{m}$.

Os materiais utilizados para a cimentação estão dispostos na tabela 3.

Tabela 3 - Cimentos utilizados e seus respectivos fabricantes

\begin{tabular}{lll}
\hline Material & Fabricante & Nome comercial \\
\hline Fosfato de zinco & S.S.White & Cimento de Zinco \\
Ionômero de vidro & $3 \mathrm{M}$ & Rely X Luting \\
Cimento resinoso & Dentsply & Enforce \\
\hline
\end{tabular}

\subsubsection{Cimentação com fosfato de zinco}

Para cimentação com fosfato de zinco, o proporcionamento e a espatulação seguiram as recomendações do fabricante.

\subsubsection{Cimentação com ionômero de vidro}

Para a cimentação com ionômero de vidro, o dente foi seco com jatos de ar com cuidado de não ressecá-lo e o proporcionamento e o tempo de espatulação seguiram as recomendações do fabricante. 


\subsubsection{Cimentação com cimento resinoso}

A estrutura dentinária foi condicionada com ácido fosfórico por 15 segundos, lavando-se o dente com água e secando-o com jatos de ar, para remoção do ácido. Em seguida foi aplicado Prime \& Bond 2.1 em toda a superfície da dentina por trinta segundos e os excessos foram removidos com leve jato de ar aplicado durante cinco segundos. O proporcionamento e o tempo de espatulação seguiram as recomendações do fabricante. Após o posicionamento da coroa total no dente preparado, a remoção dos excessos grosseiros foi feita com sonda exploradora $n^{\circ} 05$ e procedeutse a fotopolimerização por quarenta segundos em cada margem da interface dente-restauração, usando um fotopolimerizador (Optilux -Dabi Atlante).

Em todas as amostras, uma fina camada do agente cimentante foi colocado no interior das coroas com auxílio de um pincel pelo de marta $\mathrm{n}^{\circ} 00$, cobrindo as paredes axiais e o início da parede oclusal. As coroas foram posicionadas nos respectivos preparos com pressão digital por um minuto, sendo então aplicada uma

carga estática de $5 \mathrm{Kg}^{95}$, com um dispositivo especial, por dez minutos. Decorrido este tempo, os excessos de cimento das interfaces foram removidos, sendo os corpos de prova armazenados em soro fisiológico por 24 horas. (figuras 3 e 4 ) 


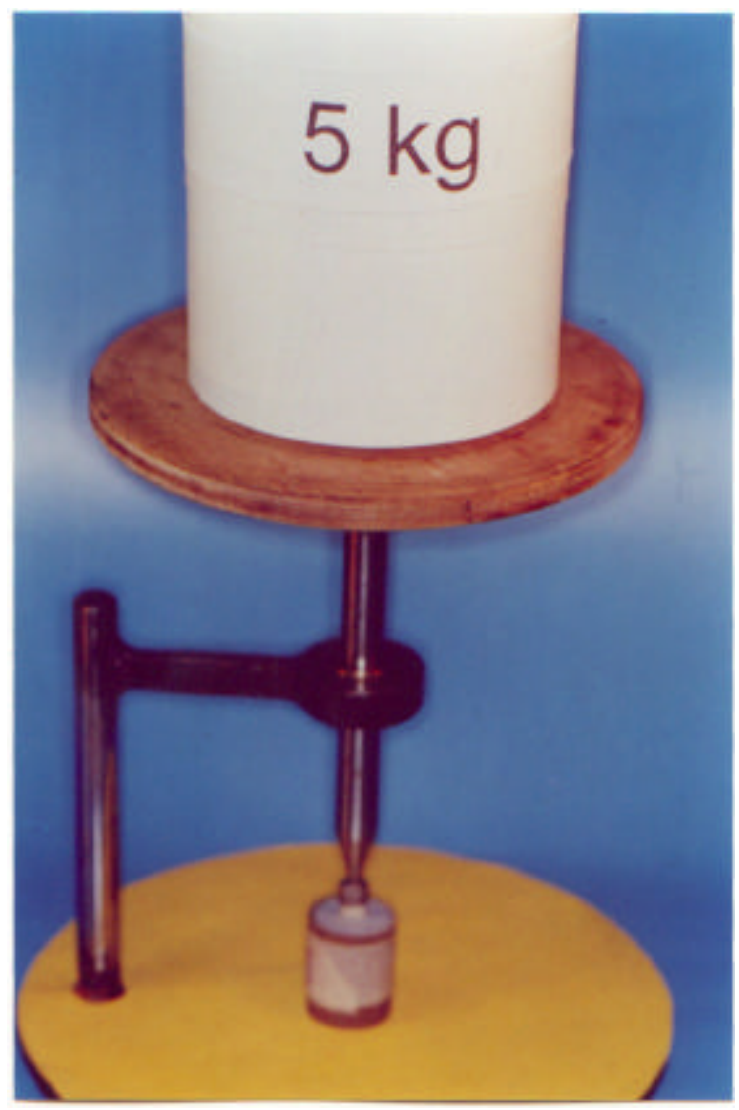

Figura 3 - Dispositivo utilizado para cimentação

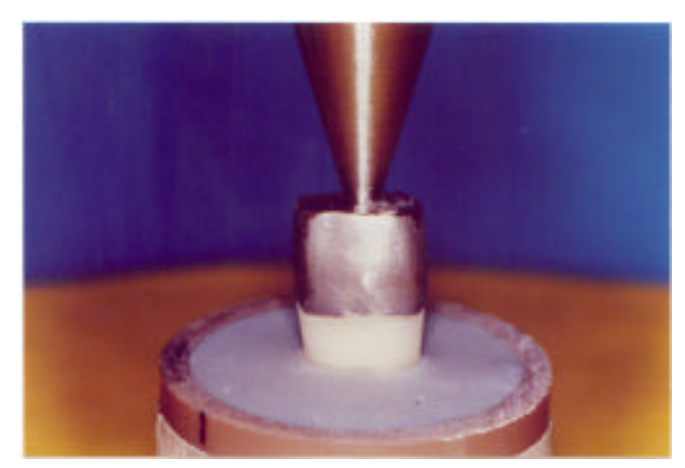

Figura 4 - Detalhe do dispositivo utilizado

Então, tomou-se a medida final da discrepância de assentamento como descrita anteriormente, sendo os valores finais obtidos pela subtração dos valores finais e iniciais, em cada face de cada corpo de prova. 


\subsection{Teste de ciclagem mecânica}

Metade dos corpos de prova foi posicionada em uma máquina específica para realização dos testes de ciclagem com carga dinâmica, desenvolvida pelo Centro Aerotécnico Espacial - Instituto de Tecnologia e Aeronáutica (São José dos Campos), localizada na disciplina de Prótese da Faculdade de Odontologia da UNESP, seguindo-se o protocolo de testes preconizados por WISKOTT et al ${ }^{134}$ (figura 5). A frequência utilizada foi de $2,5 \mathrm{~Hz}$, para uma carga de $50 \mathrm{~N}$ (aproximadamente $5 \mathrm{Kg}$ ), num total de 50.000 ciclos ininterruptos, perfazendo um total de 5 horas e 30 minutos para cada corpo de prova testado. 


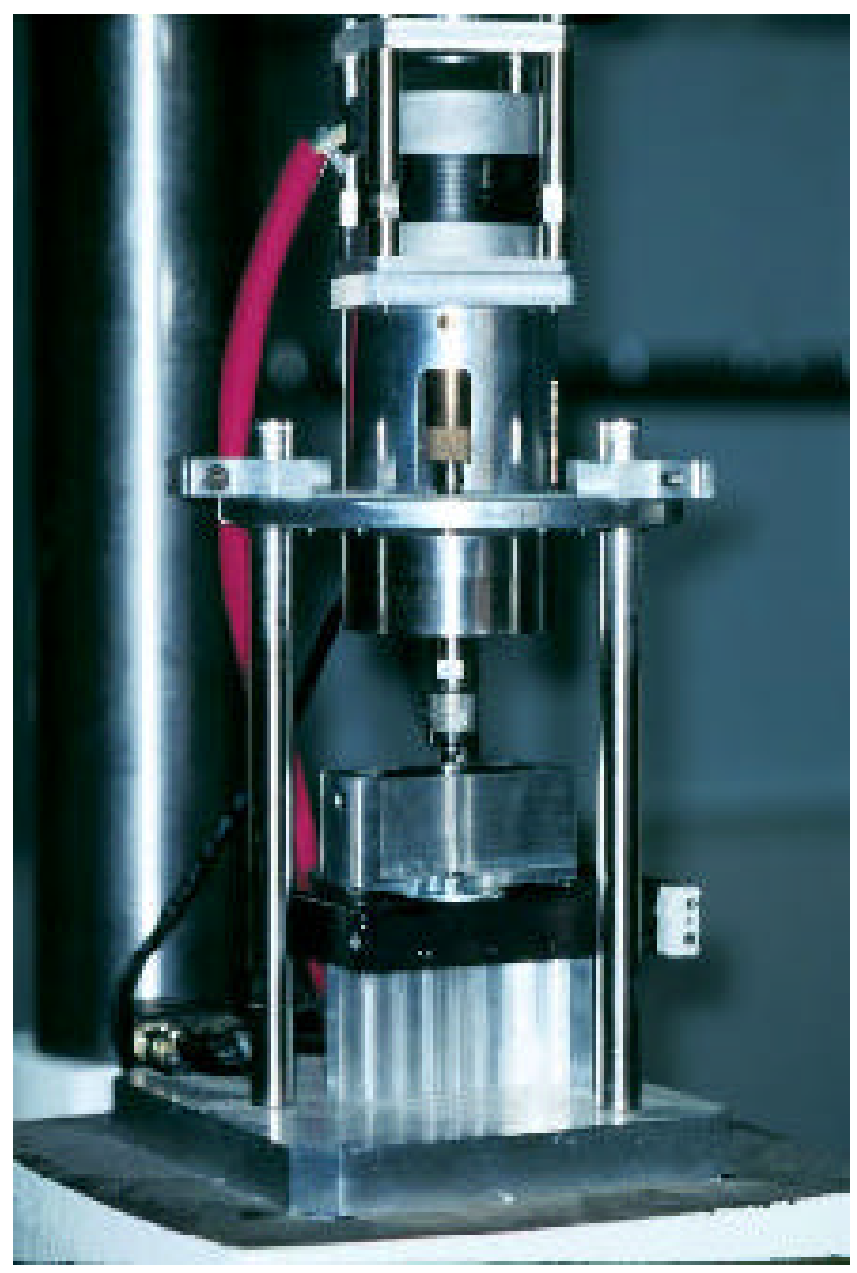

Figura 5 - Máquina de ensaios para ciclagem mecânica

A máquina de ciclagem consistia de uma braço de furadeira de bancada, onde o conjunto célula de força, motor de escalonamento (RS 440-442, 9828, 1,8DEG, 5,0V, 1,0A, TRANSTEC) e sensor controlavam a quantidade de carga aplicada, número de ciclos e o contato entre a ponta tansmissora de carga e a superfície oclusal da coroa do corpo de prova. A carga aplicada e o número de ciclos realizados era interpretado por um transdutor, $(\mathrm{N}-220$, faixa de 0 a $0,5 \mathrm{KN}, 16$ a 30Vcc, TRANSTEC - São José dos Campos- SP) acoplado a um programa de computador, que monitorava cada teste. A cada 250 ciclos, o sensor corrigia 
automaticamente o contato da ponta de carga com a superfície oclusal da coroa, sendo este ajuste automático. Após a conclusão dos testes, os corpos foram retirados da matriz de alumínio e armazenados em soro fisiológico.

Para a realização dos testes, cada corpo de prova foi acondicionado em uma matriz de alumínio, sendo suportado por duas hastes horizontais e preso verticalmente por travamento através de um degrau interno presente na matriz. A base de alumínio foi aparafusada na base da máquina de ciclagem mecânica, sendo que seu interior permitia a colocação de água destilada até a interface coroa-dente, mantida sob a temperatura de $37^{\circ} \mathrm{C}$. (figura 6)

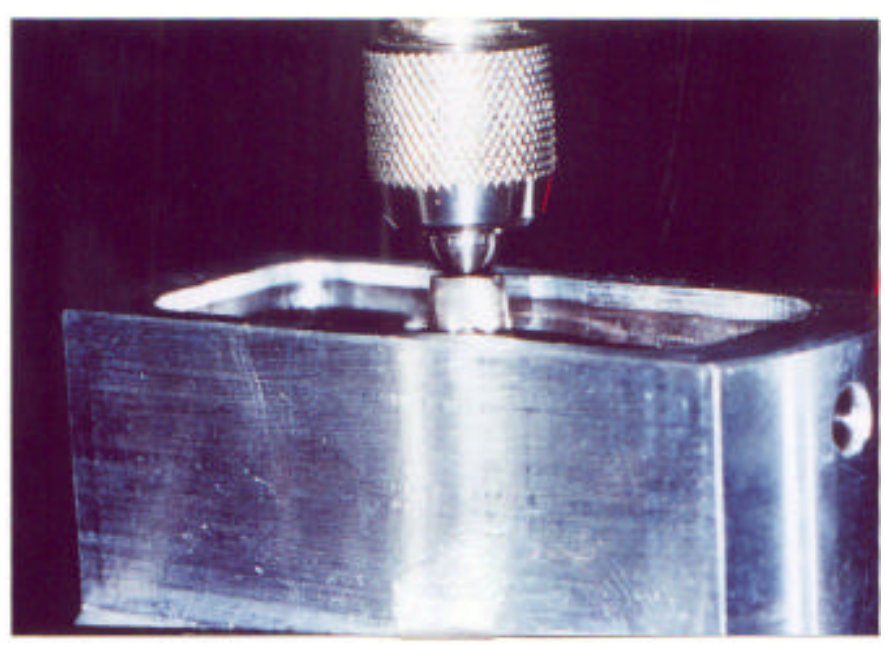

Figura 6 - Fixação do corpo de prova para ciclagem mecânica

\subsection{Ciclagem térmica}


Os corpos de prova foram então submetidos à ciclagem térmica nas temperaturas de $5^{\circ} \mathrm{C}$ no teste de resfriamento e $55^{\circ} \mathrm{C}$ no teste de aquecimento, permanecendo por um minuto em cada temperatura, num total de 300 ciclos.

\subsection{Avaliação da microinfiltração marginal ${ }^{\#}$}

Os dentes foram removidos dos cilindros de plástico e afixados a uma placa acrílica com godiva de baixa fusão (Sybron-Kerr Dental Industries), estando o longo eixo da coroa perpendicular a superfície da placa. Esta placa de resina foi acoplada a uma máquina para cortes seriados (Extec Corporation, Enfield, Connecticut, EUA), sendo que os cortes foram realizados no sentido vestíbulo-lingual com um disco de diamante (Extec Diamond Wafering Blade, ref. 12205), dividindo-se o corpo de prova em duas partes iguais. (figura 7)

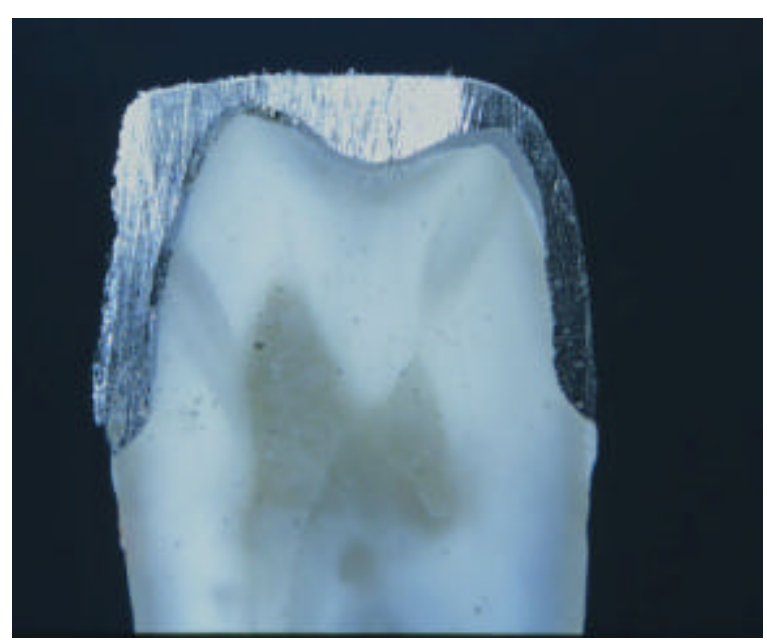

Figura 7 - Aspecto da face interna do corpo de prova após o corte

Para homogeneização das superfícies de leitura dos corpos de prova, estes foram lixados com lixas d’água das séries 1000 e 1200 (código 401Q, 3M do Brasil) em intervalos de 3 minutos, sendo os corpos posteriormente lavados em água 
destilada com auxílio do ultra-som para remoção de quaisquer resíduos. Para o polimento da face interna das amostras obtidas, foram utilizadas pastas diamantadas (METADI II - Diamond Compound for metallography, Buehler, Lake Blufford, IL, EUA) nas seguintes granulações: $q \mu \mathrm{m}$ (cor amarela), $3 \mu \mathrm{m}$ (cor verde), $1 \mu \mathrm{m}$ (cor azul) e de $0,25 \mu \mathrm{m}$ (cor cinza) em uma placa de feltro de granulação igual a da pasta, umedecida com água destilada. Pressionado-se levemente a face interna do corpo de prova contra a superfície da placa, movimentos circulares suaves e amplos foram executados em toda sua área, com a finalidade de se obter uma superfície metálica espelhada e uma superfície dentinária fosca e homogênea, livre de ranhuras. Antes da utilização de uma nova granulação para polimento, as amostras foram colocadas em um recipiente com água destilada e levadas ao ultra-som por aproximadamente três minutos, para eliminação dos resíduos.

\subsubsection{Avaliação da microinfiltração marginal em microscopia óptica}

Para a leitura do grau de microinfiltração marginal, uma solução evidenciadora de cárie (Caries Detector, J. Morita, Kuraray Co.), composta por corante ácido vermelho 52 (rodamina B) e propilenoglicol foi aplicada na superfície interna das amostras por 15 segundos, estendendo-se pela interface dente-coroacimento, sendo posteriormente lavada em água destilada por 15 segundos. Posteriormente, as amostras foram secas com papel absorvente, colocadas sobre uma lamínula de acrílico e levadas a um microscópio óptico comparador (Diaplan-Leica, Alemanha), sendo as faces internas visualizadas sob aumento de 80 vezes. 
Inicialmente, todo o perímetro interno da interface dente-cimento foi medido com auxílio do microscópio óptico. Depois, tomando-se como referências as margens vestibular e lingual dos preparos, as penetrações lineares foram quantificadas em micrometros, nas interfaces dente-cimento ${ }^{61,120,127,128,(f i g u r a ~ 8) . ~ O s ~}$ valores de microinfiltração foram anotados e dispostos nas tabelas 14 e 15, para fornecer uma estimativa da penetração linear em função do agente cimentante utilizado
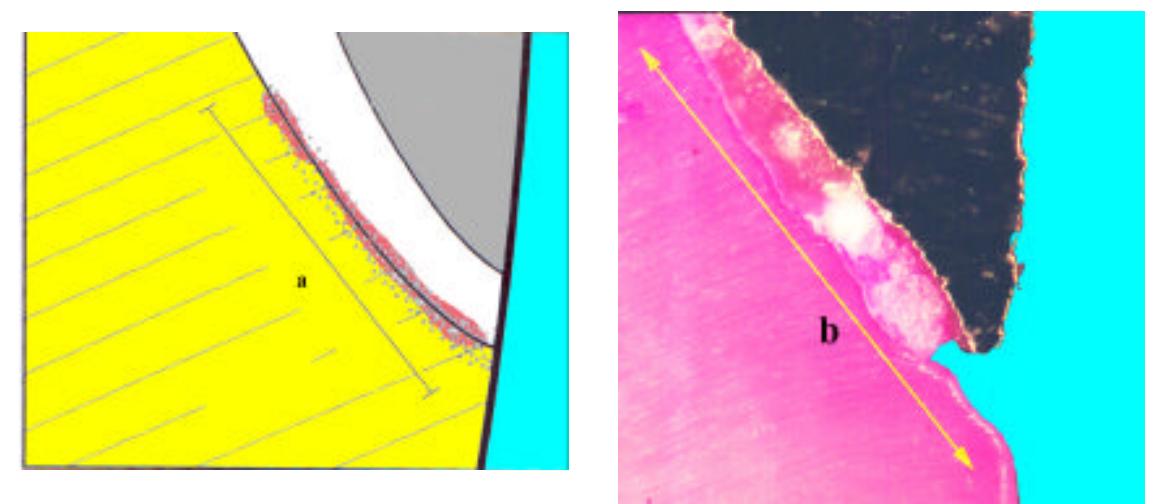

Figura 8. - Esquerda: (a) = medida linear da penetração do corante ao longo da interface dente cimento, em micrometros. Direita: $(b)=$ fotomicrografia da área marginal vestibular aberta, amostra $n^{\circ} 6$, cimento fosfato de zinco, aumento $80 \mathrm{X}$.

A utilização do agente evidenciador de cárie mostrou uma coloração púrpura de maior ou menor intensidade, de acordo com a composição química de cada agente cimentante.

\subsection{2..Avaliação da abertura marginal em microscopia eletrônica de varredura}


Posteriormente, as áreas coradas foram lavadas com água destilada e ultrasom por aproximadamente 10 minutos. Para confecção das réplicas das amostras em resina epóxica ${ }^{30}$, as superfícies foram secas em papel absorvente e moldadas com silicona de polimerização por adição (Express, 3M) (figura 9). Para o vazamento, foi utilizada mistura de resina epóxica (Buehler Epoxide Resin) e resina endurecedora (Buehler Resin Hardener) na proporção de 5 partes para uma parte, espatulando-se vigorosamente para diminuição do número de bolhas, e que foi vertida no interior do molde sob alta vibração em dispositivo apropriado. A parte superficial dos moldes foi aquecida rapidamente sob a chama de um isqueiro para diminuição do número de bolhas. As amostras foram armazenadas em estufa a $37^{\circ} \mathrm{C}$ para remoção das bolhas, permanecendo por 24 horas até o endurecimento completo da réplica.

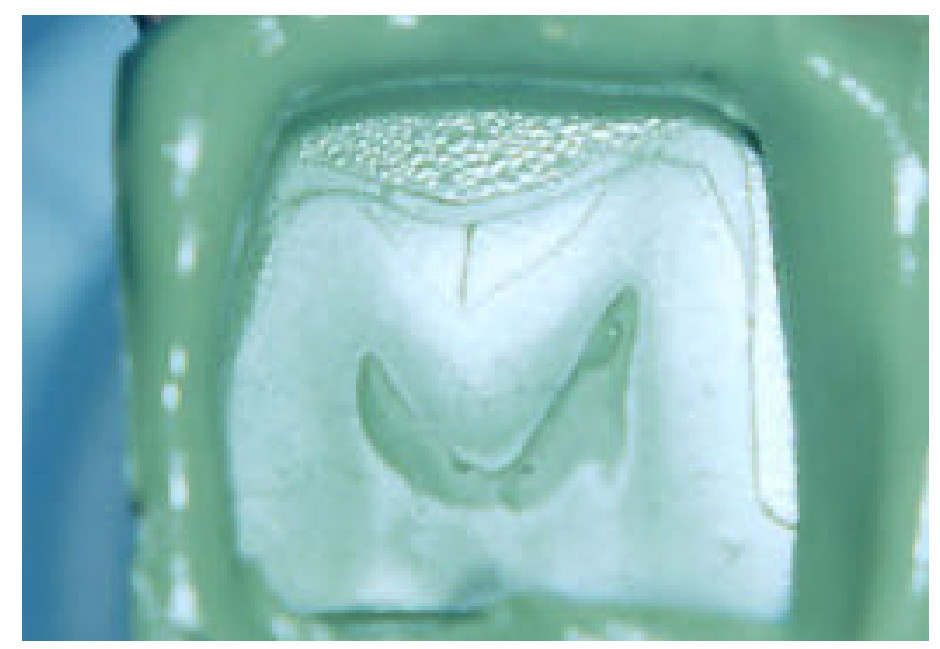

Figura 9 - Molde para vazamento das réplicas

Após a secagem das amostras, as mesmas foram retiradas dos moldes e inspecionadas. Os excessos de resina foram removidos em lixa d'água de granulação 320 (3M do Brasil) em água destilada. A superfície em análise obtida nas réplicas foi 
posicionada perpendicularmente ao cilindro de fixação com o auxílio de fita adesiva dupla face, colocada em estufa a $37^{\circ} \mathrm{C}$ para secagem por aproximadamente cinco minutos e levada ao aparelho de metalização para posterior análise em microscopia eletrônica de varredura.

O processo de metalização consistiu na colocação das réplicas com seus respectivos cilindros de fixação no interior de dispositivo apropriado (Baltec SCD 050 Sputter Coater, Balzers AG, Liechtenstein). Após a obtenção da pressão de 0,1mbar na câmara interna, gás argônio foi injetado pelo conduto de alimentação, sendo o processo repetido quatro vezes. Assim, estando a temperatura interna da câmara a $30^{\circ} \mathrm{C}$, uma corrente elétrica de $56 \mathrm{~mA}$ percorria o interior da mesma por um minuto e dez segundos. A corrente elétrica ionizava o gás, o qual fazia com que partículas de uma placa de ouro localizada na parte superior do circuito fosse depositada sobre as réplicas, resultando na metalização das mesmas.

Todas as réplicas foram retiradas e colocadas em um porta-cilindros para obtenção das imagens em microscopia eletrônica de varredura (JSM5600LV, JEOL, Japan), nos aumentos de 35 e 100 vezes, sendo registradas fotograficamente. Em todas as amostras foi medida a abertura marginal nas faces vestibular e lingual, como ilustrado na figura 11.

De maneira semelhante a figura 8 , a presença de fendas ao longo da interface dente-cimento foi medida linearmente para que se pudesse estabelecer uma correlação entre os valores obtidos em microscopia óptica com os de microscopia de varredura (Tabelas 14 e 15). Isto foi necessário já que o corante pode reagir com o 
corpo do agente cimentante e não na interface dente-cimento. Ambas as medidas foram realizadas com auxílio de um programa de computador (Adobe Photoshop 5.0), segundo os critérios estabelecidos por HOLMES et $\mathrm{a}^{46}$ (1989), (figura 10), e metodologia descrita por PASHLEY et $\mathrm{al}^{87}$.
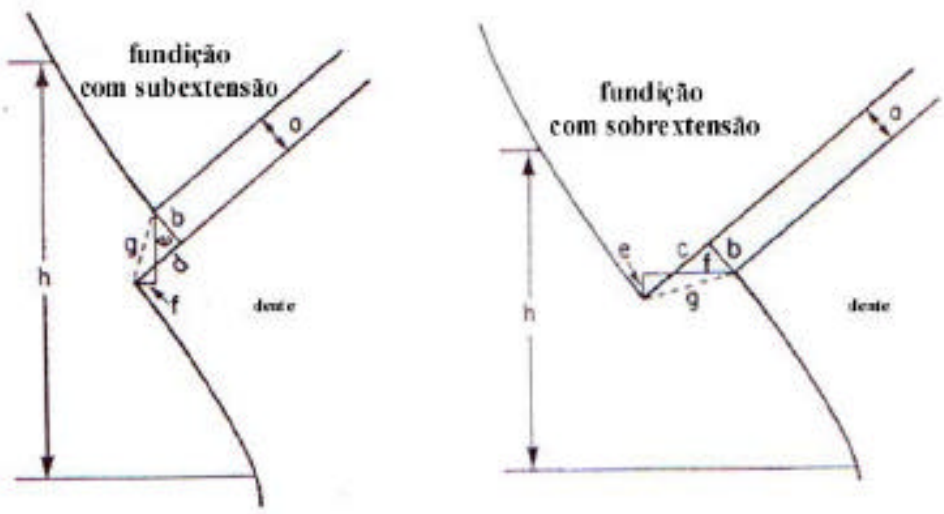

Figura 10 - $h=$ discrepância de assentamento ; $b=$ abertura marginal (espessura de película nas margens) 


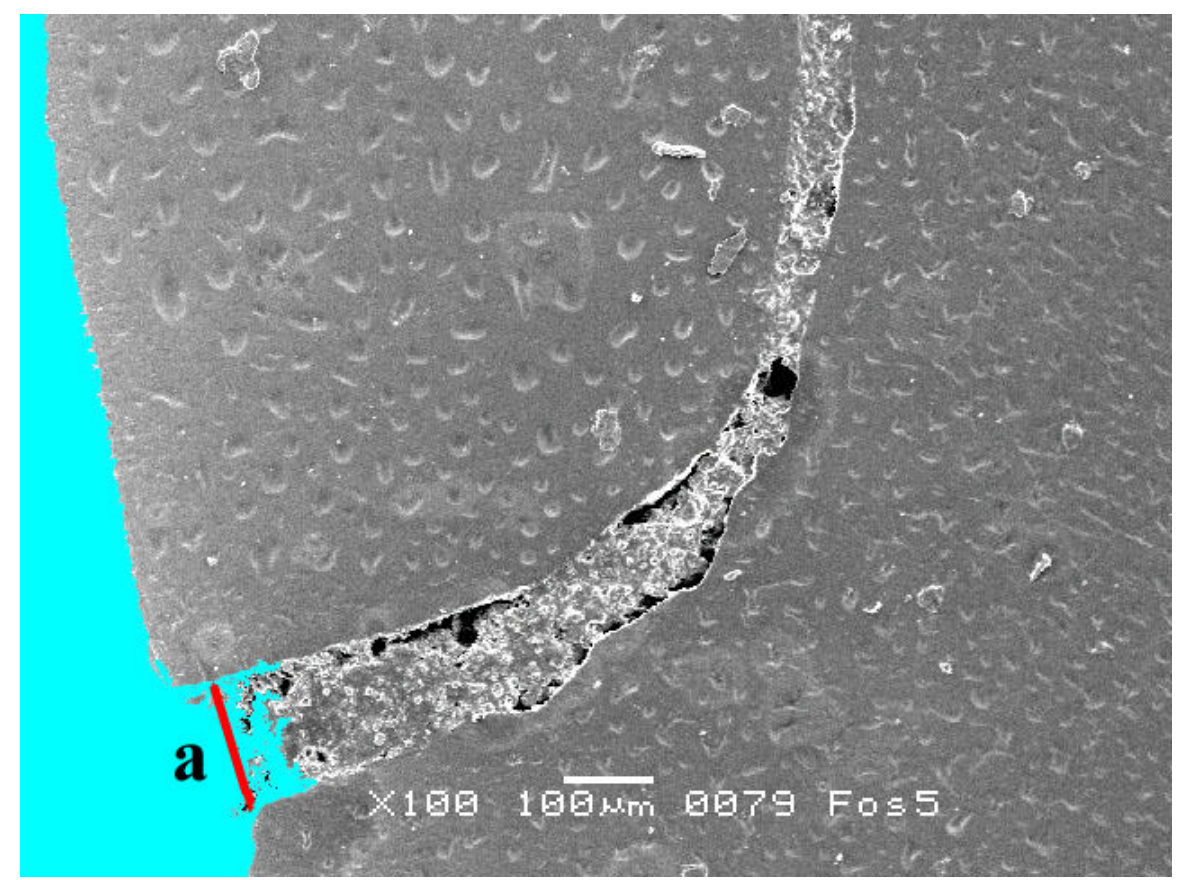

Figura 11 - Eletromicrografia da área marginal vestibular aberta, amostra $\mathrm{n}^{\circ} 5$, fosfato de zinco ; $\mathrm{a}=$ abertura marginal, $137,42 \mu \mathrm{m}$ 
RESULTADOS 


\section{RESULTADOS}

Os resultados médios das discrepâncias de assentamento (DA) e abertura marginal (AM) (interação entre as faces vestibular e lingual) podem ser visualizados na tabela 4.

Para comparação das médias foi utilizado o Teste de Kruskall Walis, seguido do teste de Dunn para comparaçoes múltiplas $(\mathrm{p}<0,05)$ que encontrou diferenças significativas entre as variáveis DA e AM para cada agente cimentante. Para a mesma variável, os cimentos não apresentaram diferenças significativas.

Tabela 4 - Médias de discrepância de assentamento (DA) e abertura marginal (AM) por agente cimentante, em micrometros. Letras iguais representam diferenças estatisticamente significativas.

\begin{tabular}{llll}
\hline Variável & & Material & \\
\hline & Fosfato & Ionômero & Resinoso \\
DA & $137,22 \mathbf{a}$ & $111,60 \mathbf{b}$ & $81,89 \mathbf{c}$ \\
AM & $78,39 \mathbf{a}$ & $78,49 \mathbf{b}$ & $75,92 \mathbf{c}$ \\
\hline
\end{tabular}

Os resultados da penetração linear do corante (PLC) (interação das faces vestibular e lingual), observados em microscopia óptica para cada agente cimentante, podem ser vistos na tabela 5 .

Para comparação das médias foi utilizado Teste de Kruskall Walis $(\mathrm{p}<0,05)$, seguido do teste de Dunn para comparações múltiplas, onde foram encontradas 
diferenças estatisticamente significativas para a infiltração marginal entre os cimentos de fosfato de zinco e ionomérico, e fosfato de zinco e resinoso, conforme tabela 5 .

Tabela 5 - Médias de penetração linear do corante (PLC) na área marginal, para cada agente cimentante, observadas ao microscópio óptico. Letras iguais representam diferenças estatisticamente significativas (PLC p=0,003)

\begin{tabular}{llll}
\hline Variável & & Material & \\
\hline & Fosfato & Ionômero & Resinoso \\
PLC & $2769,22 \mathbf{a , b}$ & $133,33 \mathbf{a}$ & $151,30 \mathbf{b}$ \\
\hline
\end{tabular}

Os valores individuais para cada corpo de prova, as médias e o desviopadrão podem ser encontrados nas Tabelas 14 e 15, que estão localizadas no capítulo de Anexos.

O grau e sentido das correlações entre as discrepâncias de assentamento (DA), abertura marginal (AM) e quantidade de microinfiltração (PLC) podem ser vistos nas tabelas 6,7 e 8 , bem como a possível correlação com as leituras realizadas em microscopia de varredura (MEV).

Tabela 6 - Coeficientes de correlação.de Spearman para o cimento fosfato de zinco

\begin{tabular}{|c|c|c|c|c|c|}
\hline Variável & Vestibular & Lingual & Geral & $\mathrm{P}$ & Sentido \\
\hline DA $x$ PLC & 0,51 & 0,52 & 0,30 & 0,43 & Fraca a média \\
\hline AM x PLC & 0,63 & $-0,33$ & 0,43 & 0,24 & Fraca a média \\
\hline DA $x$ AM & 0,28 & $-0,15$ & 0,0 & 0,0 & Inexistente \\
\hline PLC X MEV & $-0,13$ & 0,45 & 0,16 & 0,66 & Fraca \\
\hline
\end{tabular}


Tabela 7 - Coeficientes de correlação de Spearman para o cimento ionômero de vidro

\begin{tabular}{|c|c|c|c|c|c|}
\hline Variável & Vestibular & Lingual & Geral & $\mathrm{P}$ & Sentido \\
\hline DA $x$ PLC & 0,52 & 0,45 & 0,39 & 0,08 & Fraca a média \\
\hline AM x PLC & 0,17 & 0,41 & 0,30 & 0,18 & Fraca a média \\
\hline $\mathrm{DA} \times \mathrm{AM}$ & 0,33 & $-0,24$ & 0,13 & 0,55 & Fraca \\
\hline PLC X MEV & 0,57 & 0,98 & 0,60 & 0,004 & Média a forte \\
\hline
\end{tabular}

Tabela 8 - Coeficientes de correlação de Spearman para o cimento resinoso

\begin{tabular}{cccccc}
\hline Variável & Vestibular & Lingual & Geral & $\mathrm{P}$ & Sentido \\
\hline DA x PLC & 0,19 & 0,43 & 0,25 & 0,29 & Fraca \\
AM x PLC & $-0,10$ & $-0,24$ & $-0,25$ & 0,31 & Fraca \\
DA x AM & 0,76 & 0,18 & 0,51 & 0,02 & Média \\
PLC x MEV & 1,0 & 0,86 & 0,93 & 0,0 & Forte \\
\hline
\end{tabular}

Os resultados da influência da ciclagem mecânica na microinfiltração marginal (interação entre as faces vestibular e lingual), em função de cada agente cimentante podem ser vistos na tabela 9. Para comparação das médias foi utilizado o Teste de Kurskal Wallis, seguido do teste de Miller para comparações múltiplas $(\mathrm{p}<0,05)$, que mostraram diferenças na interação entre o agente cimentante e a presença de ciclagem ou não. 
Tabela 9 - Médias dos valores de infiltração (PLC) em função da presença de ciclagem mecânica ou não. Letras iguais representam diferenças estatisticamente significativas. Teste de Miller $(\mathrm{p}<0,05)$.

\section{Agente cimentante}

\begin{tabular}{llcc}
\hline Ciclagem & Fosfato & Ionômero & Resinoso \\
\hline Sim & $4221,2 \mathbf{a , b , c , d , e}$ & $145,7 \mathbf{b}$ & $314,12 \mathbf{d}$ \\
Não & $1316,7 \mathbf{a}$ & $120,9 \mathbf{c}$ & $51,33 \mathbf{e}$ \\
\hline
\end{tabular}


DISCUSSÃO 
DISCUSSÃO 86

\section{DISCUSSÃO}

Quando se analisa o processo de microinfiltração, é imprescindível que se avalie o grau de abertura marginal e é neste momento que se observam contradições nas terminologias empregadas (adaptação, desajuste, discrepância marginal, discrepância de assentamento, abertura marginal, etc.) bem como na metodologia empregada.

Assim, para facilitar a discussão dos resultados, optoutse por analisar separadamente os itens relacionados, correlacionando-os aos objetivos desta pesquisa.

\subsection{Discrepância de assentamento $x$ abertura marginal}

A palavra ajuste possui várias sinonímias e por isso quando usada como "ajuste" de uma restauração ainda cause dúvida quanto à sua interpretação. Os pontos de referência para as mensurações e a terminologia descritiva que define o ajuste variam consideravelmente entre os investigadores. Muitas vezes o mesmo termo é usado para se referir a diferentes medidas, ou diferentes termos são usados para uma mesma observação ${ }^{46}$. Adaptação marginal, adaptação interna, assentamento vertical, aparência radiográfica, aceitação clínica julgada por profissionais experientes são alguns deles. Neste trabalho, os termos "discrepância de assentamento" e "abertura marginal", referem-se, respectivamente, a "falta de assentamento verificada pela medida perpendicular ao longo do plano de inserção obtida através de determinados pontos na superfície externa da restauração e do elemento dentário" e "medida 
perpendicular da superfície interna da restauração até a margem do preparo dentário".

Do ponto de vista de erro de interpretação destas medidas, a discrepância de assentamento poderia ser considerada como sendo a medida mais crítica, o que não implica ser a mesma, necessariamente, o reflexo da discrepância vertical encontrada nas margens da restauração. Da mesma forma, poder-se-ia dizer que a abertura marginal é a mais crítica (por causa da solubilidade do agente cimentante), mas isto também não elimina o problema das margens com excesso ou falta de material restaurador.

Além da subjetividade das mesmas, as medidas das discrepâncias de assentamento não refletem uma medida real, pois tratam-se de aproximações lineares de segmentos curvos, o que pode ser evidenciado pela própria anatomia coronoradicular externa de qualquer elemento dentário ${ }^{130}$, fato este confirmado quando da análise dos estudos de perfilometria em coroas totais metálicas e metalocerâmicas $^{74}$

Embora a maioria dos estudos da literatura relate a colocação de pontos arbitrários na superfície externa das coroas, um estudo matemático com auxílio do computador provou que o limite inferior mínimo seria de 50 marcações, com intervalos de no mínimo 200 micrometros, para uma estimativa confiáve ${ }^{41}$. Neste mesmo estudo, observou-se que a medida externa em nada correlacionava-se com a 
medida interna marginal. Assim, foi necessário investigar em quais destes parâmetros enquadravam-se os estudos correspondentes as chamadas "discrepâncias", para depois compará-los com as médias obtidas neste trabalho.

Não só existe uma multiplicidade de critérios para definição do que se imagina ser o "assentamento", mas também variáveis como a quantidade de força empregada, perfuração ou não da superfície oclusal, troquel metálico ou dente natural, liga utilizada para a confecção de coroas, quantidade de material espaçador aplicado ou não e local da medida ${ }^{4,22,32,54,55,59,83,85,95,115,133}$. Isto dificulta a comparação das médias de "assentamento" entre os diferentes trabalhos disponíveis na literatura, bem como destes com os resultados desta pesquisa.

Observa-se que alguns autores 4, 22, 40, 55, 59, 99, 105 inicialmente, procuraram relacionar a espessura de película na superfície oclusal com o grau de deslocamento da coroa em relação a borda do troquel metálico ou do dente preparado. Esta aferência era realizada com micrômetro de quadrante e não fornecia a espessura de película, ao menos se a amostra fosse seccionada num plano paralelo ao longo eixo do dente.

Por outro lado, outros trabalhos $21,32,50,71,85,91$ avaliaram as espessuras de película nas margens gengivais, paredes axiais e superfícies oclusais, em coroas seccionadas longitudinalmente. Marcações de referência nas porções externas das coroas também são vistas na literatura ${ }^{14,36,54,115}$ com a finalidade de se medir a 
"abertura marginal", quando a medida representava a "discrepância de assentamento".

Alguns autores ainda realizaram marcas confiáveis nas bordas das coroas e mediram a abertura marginal 15, 68 119, 123,124. Uma quinta variante, a discrepância marginal vertical e horizontal foi tomada por DEDMON ${ }^{16,17}$; WHITE ${ }^{130}$ (1995).

Além disso, embora existam critérios definidos para a medida da discrepância de assentamento e da abertura marginal e, embora os valores do primeiro critério sejam maiores do que o do segundo (tanto neste trabalho como em outros na literatura), estas variáveis não fornecem a idéia da qualidade das margens, nem tão pouco eliminam o problema da exposição em maior ou menor grau da película de agente cimentante ${ }^{97}$.

Assim, neste trabalho optou-se pela utilização do termo "discrepância de assentamento" da coroa após a cimentação, visto que seu posicionamento durante a cimentação ocorre no sentido oblíquo e tridimensionalmente $119,124,133$ e que clinicamente, a verificação do excesso ou falta de material nas margens continua a ser realizada pelo deslizamento de uma sonda exploradora, fornecendo uma análise subjetiva $^{10}$ da abertura marginal. Porém, esta continua a ser necessária para a detecção de alteração de contorno da restauração que pode facilitar o acúmulo da placa , já que não se verifica na literatura uma relação consistente e reproduzível entre abertura marginal e presença de cárie ${ }^{7,86,87}$, levando-nos aos questionamentos 
propostos por ROULET ${ }^{97}$, em 1994, sobre qual seria a quantidade de abertura necessária nas margens para se considerar a mesma uma margem realmente ampla.

As médias gerais (envolvendo as quatro faces) da discrepância de assentamento (DA) para os três agentes cimentantes foram de: $135 \mu \mathrm{m}$ para o fosfato de zinco, $95,70 \mu \mathrm{m}$ para o ionômero de vidro e $73,86 \mu \mathrm{m}$ para o cimento resinoso (Tabelas 10, 11 e 12). Para efeito de comparação com a penetração linear do corante (PLC), as médias de DA das faces vestibular e lingual foram agrupadas 107, 127 também em função dos agentes cimentantes (Tabela 14) e os resultados médios foram: fosfato de zinco $(137,11 \mu \mathrm{m})$, ionômero de vidro $(111,60 \mu \mathrm{m})$ e cimento resinoso $(81,89 \mu \mathrm{m})$ (Tabela 4$)$, sem diferenças estatisticamente significantes entre os cimentos para a variável DA.

As medidas médias de abertura marginal (AM) nas faces vestibular e lingual foram de: fosfato de zinco $(78,39 \mu \mathrm{m})$, ionômero de vidro $(78,49 \mu \mathrm{m})$ e cimento resinoso $(75,92 \mu \mathrm{m})$. (Tabela 4$)$, sem diferenças estatisticamente significantes entre os cimentos. Quando as variáveis DA e AM foram comparadas, diferenças estatisticamente significantes foram encontradas, conforme mostrado na Tabela 4.

No presente trabalho, o nível baixo de correlação entre a discrepância de assentamento e a abertura marginal pode ser observado para todos os agentes cimentantes (valores gerais de 0 a 0,51) (Tabelas 6, 7 e 8), independente do tipo de agente cimentante utilizado. Isto mostra que as medidas de discrepância de 
DISCUSSÃO 91

assentamento não refletem a distribuição da camada de cimento por toda a restauração, aliás como comentado por GROTEN et $\mathrm{a}^{41}$. .

A média encontrada para a discrepância de assentamento para o fosfato de zinco $(135 \mu \mathrm{m})$, foi menor que a encontrada nos trabalhos de COOPER ${ }^{14}(141 \mu \mathrm{m})$, ROSENSTIEL $^{95}(152 \mu \mathrm{m})$, maior do que os trabalhos de JONES; DYKEMA; KEIN ${ }^{54}$ $(86,5 \mu \mathrm{m})$ e van NORTWICK ${ }^{115}(52 \mu \mathrm{m})$; e WHITE; KIPNIS ${ }^{123}(111 \mu \mathrm{m})$, WHITE et $\mathrm{al}^{127}(111 \mu \mathrm{m})$ e MOTTA ${ }^{77}(102,98 \mu \mathrm{m})$, e semelhante ao trabalho de FERRARI et $\mathrm{al}^{28}(129,79 \mu \mathrm{m})$.

Com relação a abertura marginal, a média encontrada para o fosfato de zinco $(78,39 \mu \mathrm{m})$ foi menor do que as obtidas por FUSAYAMA; IDE; HOSHODA ${ }^{32}$ $(110 \mu \mathrm{m})$, McLEAN; FRAUNHOFER ${ }^{71}(86,7 \mu \mathrm{m})$, semelhantes ao de PILO; CARDASH $^{92}(78,95 \mu \mathrm{m})$ e maior do que os de DIMASHKIEH; DAVIES ${ }^{21}$ $(30,85 \mu \mathrm{m})$ e PANDOLFI $^{85}(44 \mu \mathrm{m})$; TJAN et $\mathrm{al}^{106}(122 \mu \mathrm{m})$; WHITE; KIPNIS ${ }^{124}$ $(57,27 \mu \mathrm{m})$; CURTIS et $\mathrm{al}^{15}(100 \mu \mathrm{m})$; CAGIDIACO ${ }^{8}(112,5 \mu \mathrm{m})$. Essas diferenças devem-se em maior ou menor grau ao tipo e volume do dente (pré-molares ou molares), natureza do remanescente que recebeu a restauração (dentina ou padrão metálico), tipo da liga empregada para a confecção das coroas, e se o estudo foi realizado "in vivo" ou "in vitro".

Para o cimento ionômero de vidro, a média de discrepância de assentamento $(97,50 \mu \mathrm{m})$ foi maior do que os estudos de WHITE; INGLES; KIPNIS ${ }^{127}(82,8 \mu \mathrm{m})$ e menor do que o de MOTTA $^{77}(156,25 \mu \mathrm{m})$. Com relação a abertura marginal, a média 
encontrada para o ionômero de vidro $(78,49 \mu \mathrm{m})$ foi menor do que a obtida por CURTIS et $\mathrm{al}^{15}(100 \mu \mathrm{m})$ : WHITE; KIPNIS ${ }^{123}(111 \mu \mathrm{m})$ e maior do que o de WHITE; $\operatorname{KIPNIS}^{124}(57,54 \mu \mathrm{m})$.

Para o cimento resinoso, a média geral de discrepância de assentamento foi de $73,86 \mu \mathrm{m}$, menor do que o trabalho de $\operatorname{MOTTA}^{77}(97,58 \mu \mathrm{m})$. Essa comparação é prejudicada pelo número insuficiente de trabalhos existentes na literatura. Para a abertura marginal, a média de $75,92 \mu \mathrm{m}$ foi menor do que as obtidas por WHITE ; $\operatorname{KIPNIS}^{123}(333,1 \mu \mathrm{m}) ;$ WHITE; KIPNIS ${ }^{124}(160,41 \mu \mathrm{m})$. Este fato é de difícil explicação, porque o tamanho de partícula do cimento resinoso usado nesta pesquisa é de $1 \mu \mathrm{m}{ }^{96}$, ao passo que os agentes citados acima possuem tamanho de partícula de $0,03 \mu \mathrm{m}{ }^{126}$. Porém, sua composição química possui TEGDMA, componente responsável pela diminuição da viscosidade.

Quando os resultados de discrepância de assentamento (DA) e abertura marginal (AM) são comparados entre si, observa-se ausência de diferenças significativas entre duas variáveis dentro de cada grupo de agente cimentante (Tabela 4), sendo que os maiores ou menores valores encontrados podem ser justificados com base nas propriedade físicas e químicas do agentes cimentantes, tipo de teste para verificação da espessura de película, carga utilizada e técnica de cimentação.

O teste para obtenção da espessura de película preconizado pela ADA para muitos autores não reflete o valor de uma espessura, mas sim a medida da 
viscosidade ${ }^{55,56}$. A força de $5 \mathrm{Kg}$ utilizada para cimentação de todas as amostras foi padronizada na literatura ${ }^{36,57}$ sendo que forças além deste valor surtem pouco efeito na viscosidade do cimento.

Quando da análise da influência da força de assentamento sobre a espessura de película de vários agentes cimentantes ionoméricos ${ }^{57}$ e resinosos ${ }^{122}$,verificou-se que os cimentos de ionômero de vidro necessitavam de menor força para atingir a espessura mínima de película, diferente do que ocorre com os resinosos. Em outro estudo $^{121}$, verificou-se que a geração mais nova das cimentos resinosos usados para cimentação também não preenche as características ideais, sendo aconselhado para isto o uso de mais camadas espaçadoras no troquel, a fim de reduzir o grau de abertura marginal das restaurações.

Nos cimentos de fosfato de zinco, o processo de reação de presa leva a um aumento da viscosidade. Já nos cimentos de ionômero de vidro, de reação ácidobase, existe inicialmente um aumento vagaroso na viscosidade, com um aumento rápido subseque nte. Os resultados desta pesquisa estão de acordo com o de WHITE et $\mathrm{al}^{130}$, onde não foram encontradas diferenças significativas entre os cimentos fosfato de zinco e ionômero de vidro modificado por resina, lembrando que as médias de abertura marginal (AM) obtidas neste trabalho ${ }^{130}$ foram menores devido a metodologia de mensuração ser diferente. Como fator adicional, baixas concentrações de ácido tartárico aceleram o desenvolvimento da viscosidade e altas concentrações retardam. Concentrações intermediárias induzem um período 
quiescente, onde a viscosidade permanece constante. Isto é seguido por um período agudo e exponencial do aumento da viscosidade ${ }^{96}$.

Caminhando neste sentido, pode-se adotar os argumentos de TUNTIPRAWON ${ }^{111}$, de que o fato de não haver diferenças estatisticamente significativas entre os materiais para a abertura marginal pode residir no pincelamento uniforme da camada de cimento, que poderia escoar com maior eficiência pelas paredes da restauração

A análise das Tabelas 10 a 13 mostra que os valores de discrepância de assentamento (DA) para os três cimentos não podem ser considerados como padrão para correlação (fato este já visto nas Tabelas 6, 7 e 8) com a abertura marginal (AM) ou grau de infiltração (PLC). Isto é explicado devido aos coeficientes gerais de variabilidade para a DA serem mais altos (entre 49 e 94\%) do que os coeficientes de de variabilidade para a abertura marginal (entre 29 e $61 \%$ ). A alta variabilidade tanto para a DA como para a AM também é encontrada na literatura ${ }^{61,92,127}$ e explicada em função do assentamento oblíquo das restaurações fundidas.

Uma das maneiras mais práticas em se verificar o quanto uma coroa está assentada obliquamente consiste em calcular o desvio-padrão para cada amostra e observar se este valor se aproxima ou se distancia do zero. Quanto mais próximo o desvio-padrão estiver do zero, menor será o assentamento oblíquo; quanto mais longe, maior será o assentamento oblíquo ${ }^{124}$. Uma rápida análise das tabelas 10 a 13 mostra que a leitura da abertura marginal (AM) para cada corpo de prova fornece 
médias com desvios-padrão mais próximos do zero, do que os desvios-padrão vistos para as discrepâncias de assentamento (DA) e desta maneira, reafirma a hipótese de que os valores de discrepância de assentamento só fornecem uma idéia de quanto a coroa está assentada tridimensionalmente, mas não refletem a situação da camada de cimento nas margens.

\subsection{Microinfiltração marginal}

A multiplicidade de estudos na literatura acerca da avaliação da microinfiltração corrobora para a inexistência de um modelo ideal 3, 18, 29, 44, 48, 51, 53, 60, 103, 109 já que é impossível verificar os percursos de penetração sem ter a garantia da integridade física das amostras, quando do seccionamento das mesmas.

Uma das metodologias mais empregadas consiste na verficação do grau de penetração do corante, que depende do tamanho de suas partículas, polaridade molecular, capilaridade e tempo em que a amostra fica imersa na solução ${ }^{97}$.

Para este estudo, os corpos de prova foram seccionados e posteriormente corados, embora possa-se pensar que o raciocínio correto seria o de corar e depois cortar. Assim, testourse a hipótese de que se existe uma fenda marginal e ela leva a infiltração, independente do método empregado, a interface dente-cimento deverá apresentar alguma reação positiva. 
O corante utilizado neste trabalho foi o produto Caries Detector que tem em sua composição rodamina $\mathrm{B}$, solúvel em água e desta forma, interage quimicamente com os cimentos fosfato de zinco e ionômero de vidro. Este fato pode ser observado nas figuras 12 a 15, onde torna-se púrpura o corpo do agente cimentante e a interface dente-cimento. Este efeito é mais pronunciado no fosfato de zinco, menos pronunciado no ionômero de vidro e quase inexistente no cimento resinoso.

A maioria dos estudos na literatura faz referências a períodos de imersão de 24 a 72 horas. Neste estudo, o tempo de aplicação do corante foi de apenas 15 segundos, devido ao fato de que o corante entraria diretamente em contato com o cimento, independente da presença ou não de abertura marginal. Quanto maior o período de imersão, sendo o tamanho da partícula menor do que o da margem, maior será a reação regional ao corante com o cimento em função da presença de porosidades no cimento, o que pode levar a interpretações errôneas e não condizentes com o processo de infiltração. 

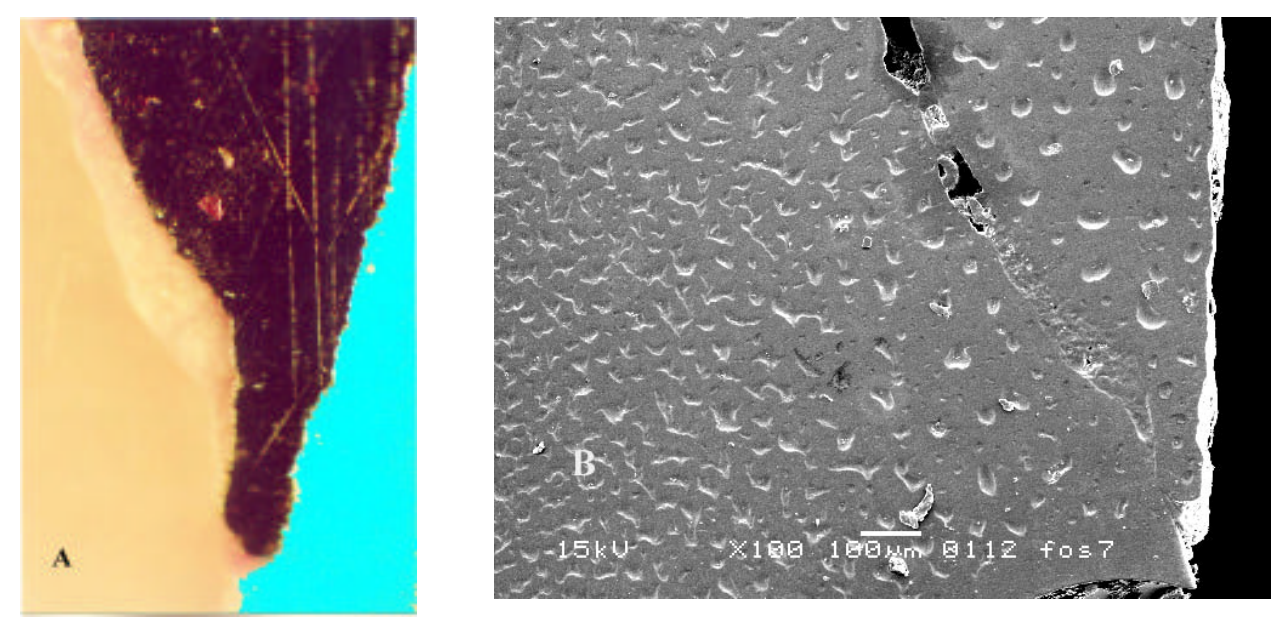

Figura 12A - Fotomicrografia da área marginal lingual adaptada, amostra $\mathrm{n}^{\circ} 7$, cimento fosfato de zinco, aumento 80X. Figura 12B - Eletromicrografia da mesma área, aumento $100 \mathrm{X}$
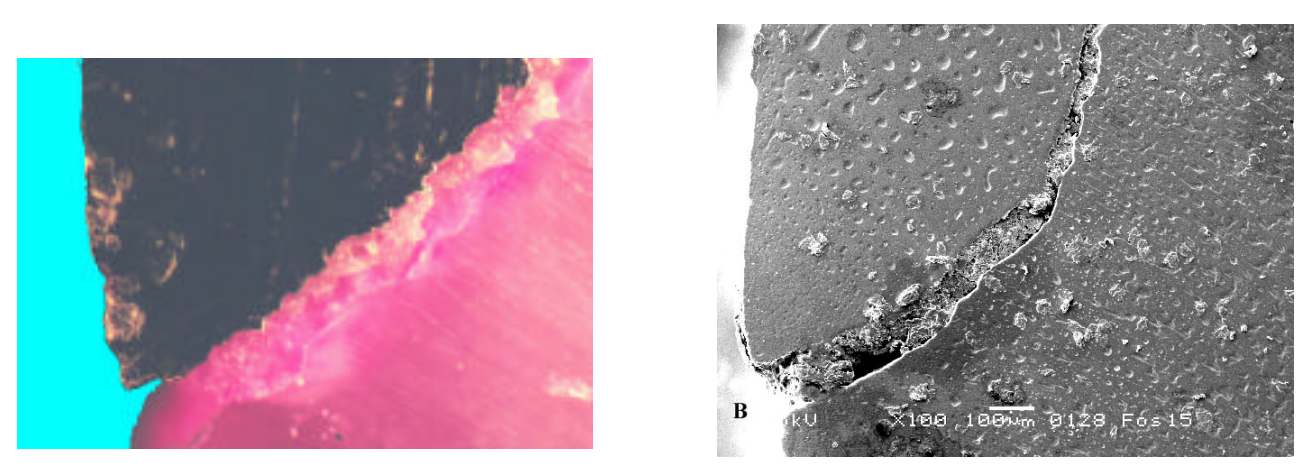

Figura 13A - Fotomicrografia da área marginal vestibular, margem aberta, amostra $\mathrm{n}^{\circ} 15$, cimento fosfato de zinco, aumento 80X. Figura 13B - Eletromicrografia da mesma área, aumento $100 \mathrm{X}$ 

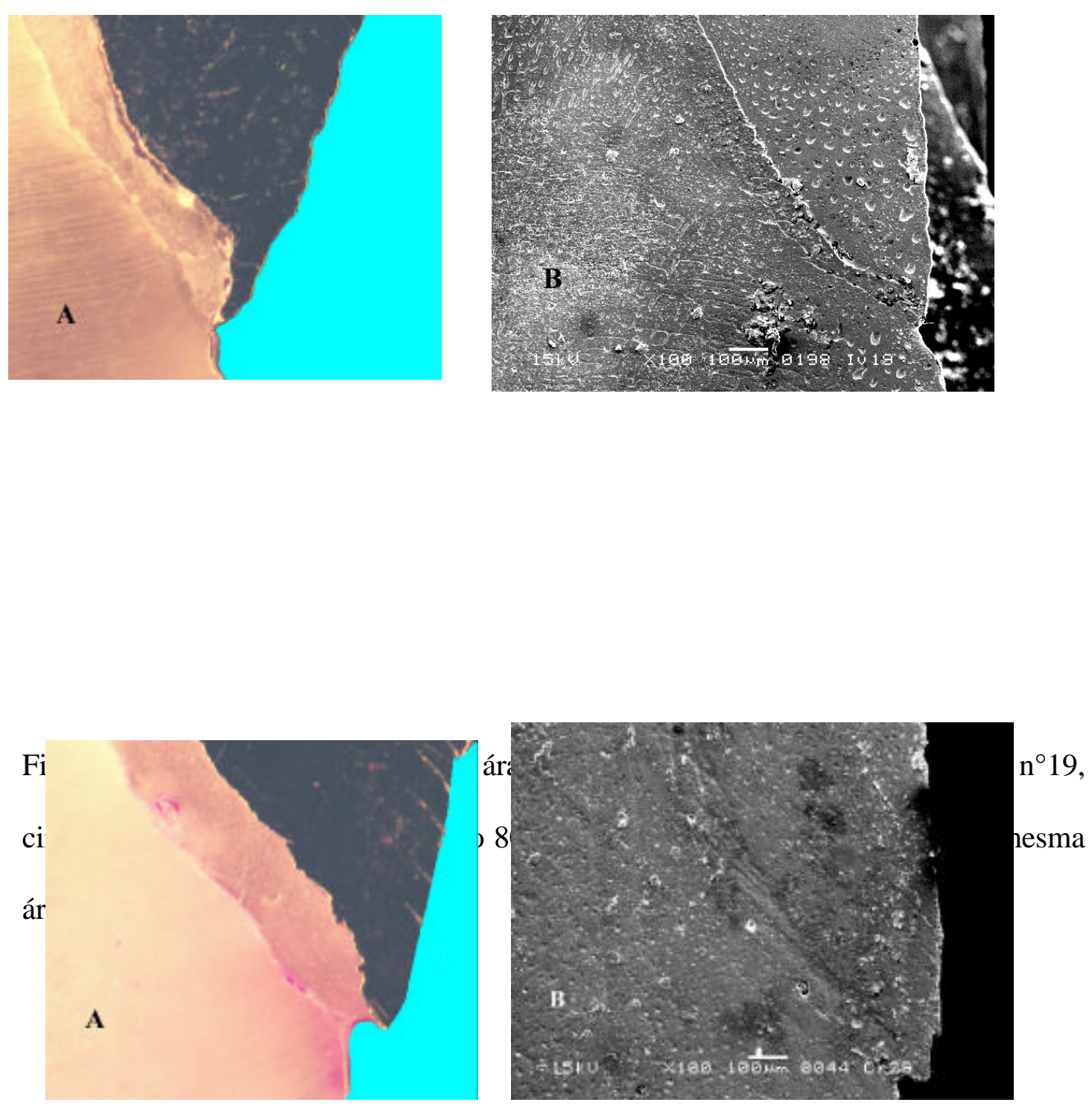

Figura 15A - Fotomicrografia da área marginal vestibular aberta, amostra $\mathrm{n}^{\circ} 29$, cimento resinoso, aumento 80X. Figura 15B - Eletromicrografia da mesma área, aumento 100X 
Uma questão que colabora para avaliação da infiltração marginal usando-se a metodologia empregada neste trabalho é que o estabelecimento de escores para a infiltração (cervical, axial, oclusal) como visto na literatura $^{11,12,13,18,25,29,31,38,44,66,79,104,106,110}$ não contribui para uma análise qualitativa . Se a margem está adaptada, tem-se menor risco de contaminação bacteriana e desenvolvimento de lesões cariosas. Se a margem está aberta, o risco torna-se maior, independente do grau de penetração. Assim, seria mais lógico adotar-se critérios absolutos como a penetração do corante existente ou ausente, e margem aberta ou adaptada.

Como as amostras foram seccionadas e depois coradas, foi necessário verificar se os valores de penetração linear obtidos em microscopia óptica (PLC) eram compatíveis com os valores obtidos em microscopia eletrônica de varredura (MEV), pela observação da interface dente-cimento, já que em alguns casos, o corpo do agente cimentante tornava-se reativo, embora a interface entre o dente e o cimento na margem estivesse neutra, como confirmado nas figuras $16 \mathrm{~A}$ e $\mathrm{B}$, fato este também observado nas figuras anteriores (figuras 12 a 15). 

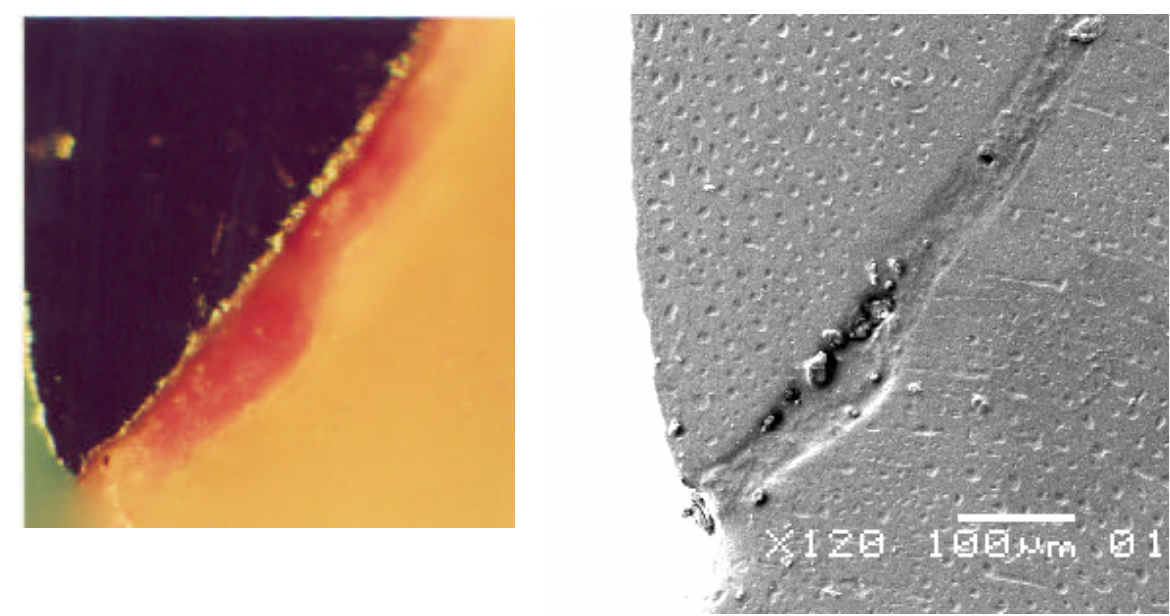

Figura 16A - Eletromicrografia da margem vestibular aberta, $\operatorname{amostra} \mathrm{n}^{\circ} 24$, cimento resinoso, aumento $100 \mathrm{X}$

Figura 16B - Fotomicrografia da mesma área, aumento 80X

Assim, a análise dos coeficientes de correlação entre os resultados de penetração linear do corante (PLC) e os de microscopia eletrônica de varredura (MEV) (Tabelas 6, 7 e 8) mostrou valor geral fraco para o cimento fosfato de zinco $(0,16)$, médio para o cimento de ionômero de vidro $(0,60)$ e forte para o cimento resinoso $(0,93)$. Da análise dos valores individuais (Tabelas 14 e 15), para o fosfato de zinco, observa-se que a microscopia óptica apresenta valores mais altos de infiltração do que em microscopia eletrônica, devido a reação química do corante com o cimento, sendo verificada infiltração em $89 \%$ das margens analisadas. Para o ionômero de vidro, esta reação dá-se em menor grau, sendo os valores de ambas as técnicas mais semelhantes. No cimento resinoso, o grau de infiltração parece depender da lei do tudo ou nada ${ }^{120,128}$, ou seja, quando da análise dos valores individuais, a concordância é maior tanto para a face vestibular como lingual, sendo 
verificado alto valor de infiltração apenas em duas amostras. Segundo PASHLEY ${ }^{87}$, estas diferenças podem ser atribuídas as falhas de adesão do agente cimentante

A análise das médias de penetração linear (PLC) deste trabalho está de acordo com os trabalhos visto na literatura ${ }^{8,61,79,104,107,108,120,127,128,129}$. ou seja, o grau de infiltração continuou sendo maior para o cimento fosfato de zinco, menor para o ionomérico e para o resinoso (Tabela 5).

Da análise estatística, verifica-se que não pode ser estabelecida uma correlação forte e positiva entre a abertura marginal (AM) e penetração linear do corante (PLC) (Tabelas 6, 7 e 8), fato este também comprovado nos trabalhos de JACOBS;WINDELER ${ }^{49}$ e nos estudos "in vitro" de WHITE; INGLES; KIPNIS ${ }^{127}$, embora os valores relativos ao cimento fosfato de zinco tenham sido elevados. Isto por si só já poderia justificar a metodologia empregada. Além disso, se a avaliação da comprovação do método fosse mais rígida, dever-se-ía empregar somente os valores lineares vistos em microscopia de varredura. Assim, encontrar-se-íam como valores gerais de correlação -0,33 para o fosfato de zinco, 0,14 para o ionômero de vidro e -0,14 para o cimento resinoso, semelhante ao estudo citado de WHITE; INGLES; KIPNIS $^{127}$ que foi de 0,07, 0,13 e -0,12 respectivamente, embora estes autores tivessem feito o processo de embebição previamente ao seccionamento das amostras. 
Neste trabalho, os valores dos coeficientes de correlação para o cimento fosfato de zinco em função das variáveis estudadas (DA e AM), mostraram uma tendência maior à infiltração, quando comparado aos coeficientes dos cimentos ionômero de vidro e resinoso. Porém, a inclusão da variável AM parece ser mais determinante na análise de possíveis correlações entre a quantidade de agente cimentante exposta nas margens e a infiltração (Tabelas 6, 7 e 8), estando em concordância com os trabalhos da literatura ${ }^{17,49}$.

Para o cimento ionômero de vidro, a correlação entre infiltração (PLC) e abertura marginal (AM) é menor e para o cimento resinoso, negativa ou fraca. $\mathrm{O}$ cimento de ionômero de vidro possui HEMA, componente possivelmente responsável pela adesão à dentina ${ }^{69}$. Para o cimento resinoso, os coeficientes de correlação foram negativos e fracos, mostrando que o condicionamento ácido seguido da aplicação de adesivo pode tornar a união dente-cimento-coroa efetiva.

Existe uma grande confusão quando se estuda a relação entre a abertura marginal e a microinfiltração. Segundo a Lei de Fick, a taxa de dissolução do agente cimentante é dependente do grau de permeabilidade do cimento e da constante de difusão do solvente (água, corante, produtos bacterianos). Isto significa que a taxa de dissolução do cimento é independente da área de agente cimentante exposta. Assim, a maioria dos testes com jato de ácido láctico empregados na literatura 62,84,91,112,118,141 mede a dissolução do agente cimentante em função do tempo, em vez 
de medir a desintegração física como mecanismo para a erosão, o que seria mais indicativo da probabilidade de microinfiltração ${ }^{96}$.

\subsection{Influência da ciclagem mecânica}

A investigação das maneiras pelas quais uma restauração pode sofrer deformação e deslocar-se do dente preparado tem sido beneficiada pela realização dos testes com ciclagem mecânica. Nos últimos anos com o auxílio da robótica ${ }^{102}$, vários aparelhos têm sido construídos com o objetivo de simular os efeitos mastigatórios, em meio seco ou úmido ${ }^{19,135-7}$. Os dispositivos mais modernos possuem atuadores nos três planos de eferência, gerando um ciclo mastigatório semelhante ao padrão humano. ${ }^{102}$

Um detalhe importante é que o teste de fadiga deve ser contínuo, já que existe a possibilidade de eventuais falhas de Griffiti sofrerem coesão quando da remoção da carga $^{134-7}$. Os testes de ciclagem mecânica apresentam como desvantagem o tempo necessário para sua realização sendo que, quanto menor a frequência de carregamento, maior o número de horas necessárias para se completar os ensaios.

A frequência de ciclos utilizada neste trabalho foi a de $2,5 \mathrm{~Hz}$ sendo que valor situa-se entre as médias utilizadas na literatura $(1,2$ a $16,6 \mathrm{~Hz})$. Esta frequência foi escolhida segundo os trabalhos pioneiros de ANDERSON ${ }^{1,2}$ e BATES; 
STAFFORD; HARRISON ${ }^{5}$, já que a frequência de mastigação de um ser humano normal situa-se ente 1,2 a 2,0Hz. A carga empregada foi de 5,0kg, sendo também similar aos estudos descritos na literatura ${ }^{26,58}$, sendo a frequência mais importante do que altos valores de carregamento 9 .

Na maioria dos estudos onde os testes de fadiga foram usados para avaliar a resistência à remoção das coroas, o número de ciclos variava de 500 a 1milhão de ciclos, ou segundo outros autores, os testes deveriam ser feitos em incrementos 23,26,31,42,47,58,65. Nos testes onde foi utilizado um número reduzido de ciclos, dificilmente saber-se-ia em qual momento do teste a coroa sofreria deslocamento, fato que pode ser verificado "in vivo", onde a restauração pode estar em função mesmo com perda de parte do cimento, devido as suas características mecânicas.

O número de ciclos utilizado neste estudo foi baixo (50.000 ciclos) correspondente aproximadamente a um período de seis meses de função da restauração, com o intuito de se detectar as alterações iniciais ocorridas na camada de cimento e seu possível papel na infiltração, já que não existem estudos na literatura onde a análise destas deformações foi realizada de maneira qualitativa ${ }^{138-40}$.

Uma estimativa mais precisa do efeito da ciclagem mecânica nos valores de PLC para cada amostra pode ser feita pela observação da Tabela 14. Para o cimento fosfato de zinco sem o efeito da ciclagem, o número de faces vestibular e lingual infiltradas foi de 5 entre 8. Com o efeito da ciclagem, o número de faces com 
infiltração foi de 9 entre 10. Para o ionômero de vidro sem o efeito da ciclagem, o número de faces infiltradas foi de 1 entre 10. Com o efeito da ciclagem, o número de faces com infiltração foi de 3 entre 10. Para o cimento resinoso sem o efeito da ciclagem, o número de faces com infiltração foi de 2 entre 10. Com o efeito da ciclagem, o número de faces com infiltração foi de 4 entre 8.

Assim, pode-se dizer que para o cimento fosfato de zinco, a ciclagem mecânica causou aumento proporcional de infiltração de 27,5\% ( 62,5 para 90\%), no cimento ionomérico, de 20\% (10 para 30\%) e no cimento resinoso de 30\%.(20 para 50\%). Embora os aumentos proporcionais entre os três cimentos tenham sido semelhantes, os valores de infiltração marginal foram significativamente maiores para o cimento fosfato de zinco em relação aos demais, o que pode ser explicado pelo fato do mesmo justapor-se ao preparo por imbricamento mecânico, fazendo com que a falha coesiva do cimento afastasse o mesmo da interface ( figura 17). A análise do modo de falha também é importante para justificar porque um cimento é mais susceptível ao processo de infiltração do que outro. Os cimentos de fosfato de zinco e os ionômeros convencionais são friáveis, isto é, falham sem deformação permanente. Os cimentos ionômero de vidro modificado por resina e os resinosos sofre deformações permanentes ${ }^{64}$ antes da fratura.

Uma possível explicação para os valores de infiltração serem menores no cimento ionômero de vidro também está no fato do mesmo unir-se ao dente por imbricamento mecânico e adesão química (figura 18). O comportamento do 
ionômero de vidro com relação a infiltração, em função da ciclagem mecânica também pode ser explicado pela propriedade de tenacidade à fratura, ou seja, a habilidade que o material apresenta para resistir a propagação de trincas ${ }^{63}$. O cimento possui resistência inicial baixa devido a reação mínima de polimerização, aumentando pelo resultado do processo continuado da cura de radicais livres.

Embora exista a possibilidade do cimento resinoso unir-se tridimensionalmente à dentina (figura 19), através da formação da camada híbrida, e de que estudos recentes mostrem que a adesão do cimento à dentina é suficiente para suportar os estresses nesta interface ${ }^{80}$, os valores de infiltração quando do uso de ciclagem foram mairores se comparados aos do ionômero de vidro (Tabela 9).

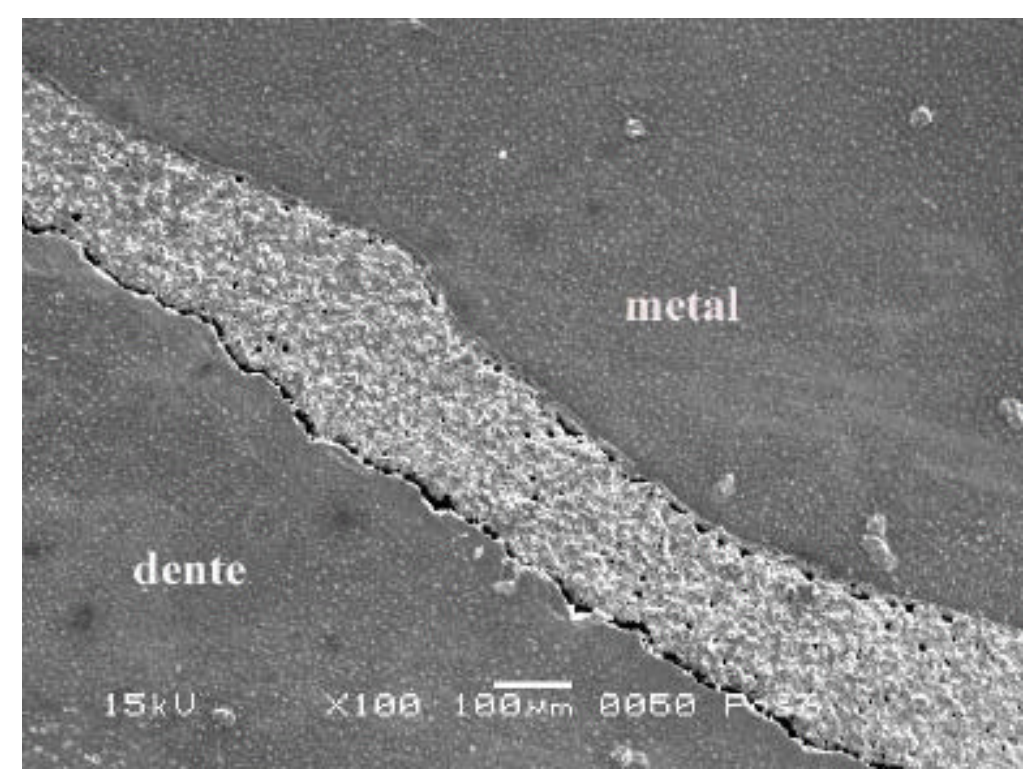

Figura 17 - Eletromicrografia da região oclusal, amostra $n^{\circ} 6$, cimento fosfato de zinco, aumento $100 \mathrm{X}$ 
DISCUSSÃO 107

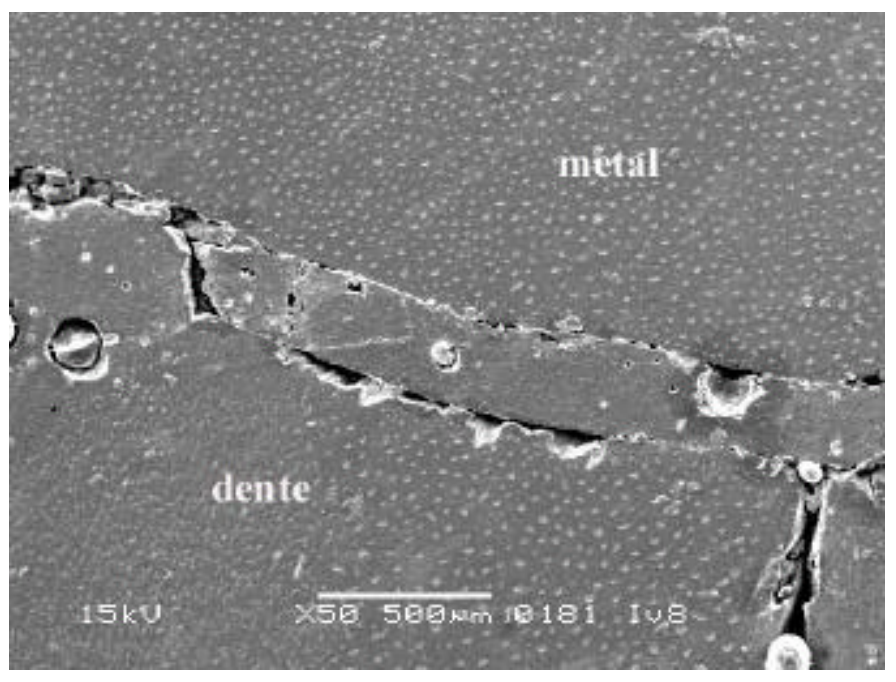

Figura 18 - Eletromicrografia da região oclusal, amostra $n^{\circ} 8$, cimento ionômero de vidro, aumento 50X

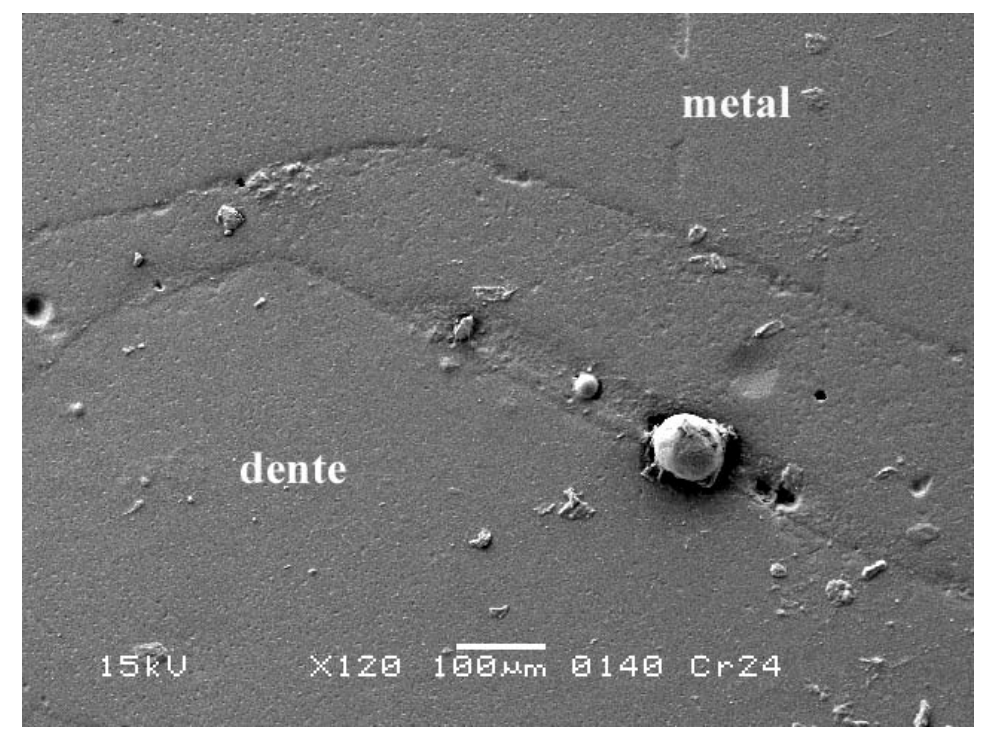

Figura 19 - Eletromicrografia da região oclusal, amostra $n^{\circ} 24$, cimento resinoso, aumento $120 \mathrm{X}$ 
Embora os valores de infiltração (PLC) em função da ciclagem sejam comparativamente mais altos para o fosfato de zinco, os estudos existentes na literatura $^{52,61,92}$ mostram que as próteses fixas cimentadas com este agente podem permanecer em função por mais de 20 anos, embora uma relação causa-efeito para este fato seja desconhecida, já que estes estudos são retrospectivos ou realizados em multicentros, onde o controle de todas as variáveis torna-se impossíve $e^{98,113,116}$.

Mesmo com os cimentos de ionômero de vidro e resinoso apresentando propriedades melhoradas, a falta de estudos clínicos longitudinais ainda impossibilita uma comparação direta com os cimentos tradicionais. Isto talvez possa ser creditado a sensibilidade da técnica de cimentação em função do uso de sistemas adesivos, dificuldade de isolamento absoluto em preparos totais para coroas metalocerâmicas ou custo elevado em comparação ao cimento fosfato de zinco.

O que se deseja clinicamente é que as pequisas caminhem no sentido de se estabelecer uma relação tridimensionalmente duradoura entre a restauração, cimento e dente preparado, impossibilitando a dissolução do agente cimentante no meio oral. Assim é importante que pesquisas sejam realizadas com objetivo de melhorar as propriedades dos agentes cimentantes, em função dos estresses mastigatórios. 
CONCLUSÕES 


\section{7 - CONCLUSÕES}

Dentro dos limites deste estudo pode-se concluir:

1- Não foi encontrada uma correlação forte e positiva entre a discrepância de assentamento, abertura marginal e a infiltração para os três cimentos analisados

2- Os resultados de discrepância de assentamento foram maiores para o cimento fosfato de zinco, seguido do ionômero de vidro e cimento resinoso, sem diferenças estatisticamente significativas

3- Os resultados de abertura marginal foram maiores para o cimento fosfato de zinco, seguido do cimento de ionômero de vidro e resinoso, sem diferenças estatisticamente significativas

4- Foram encontradas diferenças estatisticamente significativas entre a discrepância de assentamento e a abertura marginal para os três cimentos analisados

5- Os resultados de infiltração foram maiores para o cimento fosfato de zinco, seguido do ionômero de vidro e resinoso, com diferenças estatisticamente significantes entre os cimentos analisados 
6- A influência da ciclagem mecânica aumentou a microinfiltração marginal para o cimento fosfato de zinco, com diferenças estatisticamente significativas em relação aos cimentos ionômero de vidro e resinoso

7- A análise ao microscópio de varredura detectou melhor qualidade de união na interface dente-cimento para o sistema resinoso, seguida pelos cimentos ionômero de vidro e fosfato de zinco, mesmo sob influência de ciclagem mecânica 
ANEXOS 


\section{ANEXOS}

As tabelas 10,11 e 12 mostram os valores individuais em micrometros para as faces vestibular, lingual, mesial e distal, das discrepâncias gerais de assentamento (DA), em função dos agentes cimentantes utilizados

Tabela 10 - Resultados em micrometros da discrepância de assentamento das coroas cimentadas com cimento fosfato de zinco

\begin{tabular}{lllll}
\hline Número da amostra & Vestibular & Mesial & Lingual & Distal \\
\hline $\mathbf{0 1}$ & 328 & 57 & 52 & 244 \\
$\mathbf{0 2}$ & 155 & 105 & 161 & 164 \\
$\mathbf{0 4}$ & 16 & 19 & 13 & 24 \\
$\mathbf{0 7}$ & 214 & 65 & 54 & 85 \\
$\mathbf{1 5}$ & 136 & 72 & 112 & 210 \\
$\mathbf{0 3 *}$ & 149 & 154 & 260 & 144 \\
$\mathbf{0 5 *}$ & 290 & 47 & 249 & 268 \\
$\mathbf{0 6 *}$ & 160 & 80 & 154 & 130 \\
$\mathbf{1 0 *}$ & 22 & 238 & 279 & 142 \\
$\mathbf{1 4 *}$ & 29 & 420 & 17 & 23 \\
Média & 130,11 & 133,33 & 144,33 & 129,22 \\
d.p & 93,16 & 125,58 & 103,38 & 82,76 \\
& & & & \\
\hline
\end{tabular}

* corpos submetidos a ciclagem mecânica 
Tabela 11 - Resultados em micrometros da discrepância de assentamento das coroas cimentadas com cimento ionômero de vidro

\begin{tabular}{|c|c|c|c|c|}
\hline Número da amostra & Vestibular & Mesial & Lingual & Distal \\
\hline 08 & 154 & 13 & 138 & 42 \\
\hline 11 & 43 & 111 & 90 & 130 \\
\hline 17 & 126 & 42 & 189 & 147 \\
\hline 20 & 16 & 26 & 8 & 55 \\
\hline 22 & 281 & 45 & 83 & 59 \\
\hline 09* & 198 & 231 & 158 & 7 \\
\hline $12 *$ & 343 & 77 & 80 & 309 \\
\hline $18 *$ & 58 & 74 & 74 & 27 \\
\hline $19 *$ & 54 & 47 & 45 & 45 \\
\hline $21 *$ & 23 & 50 & 71 & 131 \\
\hline Média & 129,60 & 71,60 & 93,60 & 95,20 \\
\hline d.p & 113,70 & 62,50 & 53,86 & 89,19 \\
\hline
\end{tabular}

* corpos submetidos a ciclagem mecânica 
Tabela 12 - Resultados em micrometros da discrepância de assentamento das coroas cimentadas com cimento resinoso

\begin{tabular}{lllll}
\hline Número da amostra & Vestibular & Mesial & Lingual & Distal \\
\hline $\mathbf{1 3}$ & 13 & 3 & 42 & 54 \\
$\mathbf{2 3}$ & 194 & 70 & 57 & 83 \\
$\mathbf{2 8}$ & 229 & 68 & 165 & 16 \\
$\mathbf{2 9}$ & 13 & 123 & 32 & 105 \\
$\mathbf{3 0}$ & 84 & 170 & 118 & 75 \\
$\mathbf{1 6 *}$ & 127 & 124 & 97 & 14 \\
$\mathbf{2 4 *}$ & 8 & 41 & 166 & 114 \\
$\mathbf{2 5 *}$ & 79 & 30 & 66 & 76 \\
$\mathbf{2 6 *}$ & 94 & 30 & 19 & 17 \\
$\mathbf{2 7 *}$ & 47 & 31 & 48 & 79 \\
Média & 84,55 & 62,89 & 79,22 & 68,78 \\
d.p & 79,43 & 52,92 & 56,21 & 34,35 \\
\hline & & & & \\
\hline
\end{tabular}

*corpos submetidos a ciclagem mecânica 
A tabela 13 mostra os valores individuais de abertura marginal (AM) em micrometros para as faces vestibular e lingual, em função do agente cimentante utilizado.

Tabela 13 - Valores individuais de abertura marginal (AM) em micrometros para as faces vestibular e lingual, em função do agente cimentante utilizado

\begin{tabular}{|c|c|c|c|c|c|c|c|c|}
\hline \multirow[t]{2}{*}{$\mathbf{N}^{\circ}$} & \multicolumn{2}{|l|}{ Fosfato } & \multirow[t]{2}{*}{$\mathbf{N}^{\circ}$} & \multicolumn{2}{|c|}{ Ionômero } & \multirow[t]{2}{*}{$\mathbf{N}^{\circ}$} & \multicolumn{2}{|c|}{ Resinoso } \\
\hline & $\mathbf{V}$ & $\mathbf{L}$ & & $\mathbf{V}$ & $\mathbf{L}$ & & $\mathbf{V}$ & $\mathbf{L}$ \\
\hline 2 & 72,74 & 98,50 & 8 & 88,43 & 68,31 & 13 & 61,63 & 63,04 \\
\hline 4 & 66,25 & 64,53 & 11 & 47,08 & 41,00 & 23 & 119,50 & 104,36 \\
\hline 7 & 77,10 & 74,80 & 17 & 95,43 & 46,54 & 28 & 86,00 & 137,50 \\
\hline 15 & 86,44 & 102,52 & 20 & 64,09 & 70,00 & 29 & 31,00 & 76,50 \\
\hline $3 *$ & 90,53 & 38,53 & 22 & 42,00 & 61,98 & 30 & 73,31 & 91,50 \\
\hline $5 *$ & 137,42 & 63,88 & $09 *$ & 149,00 & 85,46 & $24 *$ & 0 & 42,16 \\
\hline $6 *$ & 47,11 & 62,79 & $12 *$ & 77,80 & 174,00 & $25 *$ & 121,50 & 121,00 \\
\hline $10 *$ & 60,50 & 46,16 & $18^{*}$ & 66,50 & 108,00 & $26 *$ & 72,13 & 90,50 \\
\hline $14 *$ & 120,76 & 80,42 & $19 *$ & 76,49 & 59,29 & $27 *$ & 32,50 & 42,50 \\
\hline+ & & & $21^{*}$ & 76,50 & 72,00 & ++ & & \\
\hline Média & 84,31 & 72,47 & & 78,33 & 78,65 & & 66,39 & 85,45 \\
\hline d.p. & 28,84 & 21,73 & & 29,87 & 38,48 & & 40,55 & 32,96 \\
\hline
\end{tabular}

*corpos submetidos a ciclagem mecânica

$+;++=$ corpos de prova não utilizados ( números1 e 16) 
Tabela 14 - Valores individuais de penetração linear do corante (PLC) em micrometros observados ao microscópio óptico, em função do agente cimentante utilizado

\begin{tabular}{|c|c|c|c|c|c|c|c|c|}
\hline \multirow{2}{*}{$\mathbf{N}^{\circ}$} & \multicolumn{2}{|l|}{ Fosfato } & \multirow{2}{*}{$\mathbf{N}^{\circ}$} & \multicolumn{2}{|c|}{ Ionômero } & \multirow[t]{2}{*}{$\mathbf{N}^{\circ}$} & \multicolumn{2}{|c|}{ Resinoso } \\
\hline & $\mathbf{V}$ & $\mathbf{L}$ & & $\mathbf{V}$ & $\mathbf{L}$ & & $\mathbf{V}$ & $\mathbf{L}$ \\
\hline 2 & 0 & 0 & 8 & 0 & 1209,0 & 13 & 0 & 0 \\
\hline 4 & 2483,5 & 1821,0 & 11 & 0 & 0 & 23 & 0 & 0 \\
\hline 7 & 4352,5 & 0 & 17 & 0 & 0 & 28 & 0 & 215,5 \\
\hline 15 & 2240,5 & 2270,0 & 20 & 0 & 0 & 29 & 0 & 0 \\
\hline+ & & & 22 & 0 & 0 & 30 & 297,8 & 0 \\
\hline Média & 2269,1 & 1022,8 & & 0 & 241,8 & & 59,56 & 43,1 \\
\hline d.p. & 1782,8 & 1195,1 & & 0 & 540,6 & & 133,1 & 93,6 \\
\hline $3 *$ & 6639,5 & 0 & 09* & 0 & 733,5 & $24 *$ & 0 & 88,5 \\
\hline $5 *$ & 7831,0 & 7584,0 & $12 *$ & 491,5 & 232,7 & $25 *$ & 0 & 0 \\
\hline $6^{*}$ & 3192,0 & 2368,0 & $18 *$ & 0 & 0 & $26^{*}$ & 964,5 & 0 \\
\hline $10 *$ & 2114,2 & 1728,5 & $19 *$ & 0 & 0 & $27 *$ & 660,0 & 800,0 \\
\hline $14 *$ & 4310,2 & 6450,0 & $21 *$ & 0 & 0 & ++ & & \\
\hline Média & 4817,3 & 3626,1 & & 98,3 & 193,2 & & 406,1 & 222,1 \\
\hline d.p. & 2377,4 & 3239,2 & & 219,8 & 318,3 & & 485,1 & 387,5 \\
\hline
\end{tabular}


Tabela 15 - Valores individuais de infiltração em micrometros observados ao microscópio eletrônico de varredura (MEV), em função do agente cimentante utilizado.

\begin{tabular}{|c|c|c|c|c|c|c|c|c|}
\hline \multirow{2}{*}{$\mathbf{N}^{\circ}$} & \multicolumn{2}{|l|}{ Fosfato } & \multirow[t]{2}{*}{$\mathbf{N}^{\circ}$} & \multicolumn{2}{|c|}{ Ionômero } & \multirow[t]{2}{*}{$\mathbf{N}^{\circ}$} & \multicolumn{2}{|c|}{ Resinoso } \\
\hline & $\mathbf{V}$ & $\mathbf{L}$ & & $\mathbf{V}$ & $\mathbf{L}$ & & $\mathbf{V}$ & $\mathbf{L}$ \\
\hline 2 & 0 & 0 & 8 & 0 & 554,2 & 13 & 0 & 0 \\
\hline 4 & 984,50 & 799,40 & 11 & 0 & 0 & 23 & 0 & 0 \\
\hline 7 & 741,5 & 0 & 17 & 796,5 & 0 & 28 & 0 & 215,5 \\
\hline 15 & 1177,3 & 744,5 & 20 & 0 & 0 & 29 & 0 & 0 \\
\hline+ & & & 22 & 0 & 0 & 30 & 297,8 & 0 \\
\hline Média & 725,8 & 385,9 & & 159,3 & 110,8 & & 59,5 & 43,1 \\
\hline d.p. & 515,6 & 446,2 & & 356,2 & 247,8 & & 133,1 & 96,3 \\
\hline $3 *$ & 758,0 & 0 & $09 *$ & 0 & 758,40 & $24 *$ & 0 & 0 \\
\hline $5 *$ & 290,0 & 860,8 & $12 *$ & 677,6 & 232,7 & $25 *$ & 0 & 0 \\
\hline $6 *$ & 160,0 & 0 & $18 *$ & 0 & 0 & $26 *$ & 962,5 & 0 \\
\hline $10 *$ & 22,00 & 0 & $19 *$ & 0 & 0 & $27 *$ & 660,0 & 800,0 \\
\hline $14 *$ & 724,5 & 767,6 & $21 *$ & 0 & 0 & ++ & & \\
\hline Média & 390,9 & 325,6 & & 135,5 & 198,2 & & 405,6 & 200,0 \\
\hline d.p. & 333,7 & 447,1 & & 303,3 & 328,9 & & 484,3 & 400,0 \\
\hline
\end{tabular}


Tabela 16 - Valores individuais das médias gerais de discrepância de assentamento (DA) em função das dimensões de cada amostra -

\begin{tabular}{|c|c|c|c|c|c|c|}
\hline Material & $\begin{array}{c}\text { Amostra } \\
\text { P-P }\end{array}$ & Média & $\begin{array}{c}\text { Amostra } \\
\text { M-M }\end{array}$ & Média & $\begin{array}{c}\text { Amostra } \\
\text { G-G }\end{array}$ & Média \\
\hline \multirow{4}{*}{$\begin{array}{l}\text { Fosfato } \\
\text { de zinco }\end{array}$} & 1 & 170,25 & 4 & 18,00 & 2 & 146,25 \\
\hline & 3 & 176,75 & 5 & 213,50 & 14 & 122,25 \\
\hline & 7 & 104,50 & 6 & 131,00 & 15 & 132,50 \\
\hline & & & 10 & 170,25 & & \\
\hline Média & & 150,50 & & 133,18 & & 133,66 \\
\hline \multirow{4}{*}{$\begin{array}{l}\text { Ionômero } \\
\text { de vidro }\end{array}$} & 8 & 86,75 & 12 & 202,25 & 17 & 126,00 \\
\hline & 9 & 148,50 & 18 & 58,25 & 21 & 68,75 \\
\hline & 11 & 93,50 & 19 & 47,75 & 22 & 117,00 \\
\hline & & & 20 & 26,25 & & \\
\hline Média & & 109,58 & & 83,62 & & 103,91 \\
\hline \multirow{4}{*}{$\begin{array}{l}\text { Cimento } \\
\text { resinoso }\end{array}$} & 13 & 28,00 & 25 & 62,75 & 23 & 101,00 \\
\hline & 16 & 90,50 & 26 & 40,00 & 24 & 82,25 \\
\hline & 28 & 119,50 & 27 & 51,25 & 30 & 111,75 \\
\hline & & & 29 & 68,25 & & \\
\hline Média & & 79,33 & & 55,56 & & 100,33 \\
\hline & & & & & & \\
\hline
\end{tabular}


REFERÊNCIAS BIBLIOGRÁFICAS 


\section{REFERÊNCIAS BIBLIOGRÁFICAS*}

1. ANDERSON, D.J. Measurement of stress in mastication. Part I. J. dent. Res., v.35, n.5, p.664-70, Oct 1956.

2. ANDERSON, D.J. Measurement of stress in mastication. Part II. J. dent. Res., v.35, n.5, p.671-73, Oct 1956.

3. ALANI, A .H.; TOH, C.G. Detection of microleakage around dental restorations: a review. Oper. Dent., v.22, n.4, p.173-85, Jul/Aug 1997.

4. BASSETT, R.W. Solving the problems of cementing the full veneer cast gold crown. J. prosth. Dent., v.16, n.4, p.740-7, Jul/Aug 1966.

5. BATES, J.F.; STAFFORD, G.D.; HARRISON, A. Masticatory function - a review of the literature: part II - speed of movement of the mandible, rate of chewing and forces developed in chewing. J. oral Rehab., v.2, p.349-61, 1975.

6. BRACKETT, W.W.; VICKERY, J.M. The influence of mixing temperature and powder/liquid ratio on the film thickness of three glass-ionomer cements. Int. J. Prosthodont., v.7, n. ,p-13-6, 1994.

\footnotetext{
* Normas recomendadas para uso no âmbito da Universidade de São Paulo, com base no documento "Referências Bibliográficas: exemplos", emanado do Conselho Supervisor do Sistema Integrado de Bibliotecas da USP, em reunião de 20 de setembro de 1990.
} 
7. BRÄNNSTRÖM, M. Reducing the risk of sensitivity and pulpal complications after the placement of crowns and fixed partial dentures. Quintessence Int ., v.27, n.10, p.673-8, 1996.

8. CAGIDIACO, M.C. et al. Cement thickness and microleakage under metalceramic restorations with a facial butted margin: an in vivo investigation. Int. J. Periodont. Restorat. Dent., v.12, n.4, p.325-31, 1992.

9. CATOVIC, A. et al. .The response of human premolars to cyclic loading. J. oral Rehab., v.24, n.4, Apr 1997.

10. CHRISTENSEN, G.J. Marginal fit of gold inlay castings. J. prosth. Dent., v.16, n.2, p.297-305, Mar / Apr 1966.

11. COLEMAN, A. J. Macromolecular leakage beneath full cast crowns. Part I: The diffusion of lipopolysaccharide and dextran. J. prosth. Dent., v.74, n.2, p.187-97, Aug 1995.

12. COLEMAN, A. J. Macromolecular leakage beneath full cast crowns. Part II: The diffusion of lipopolysaccharide and dextran. J. prosth. Dent., v.75, n.1, Jan 1996. 
13. COLEMAN, A .J.; MOSES, M.S.; RICKERBY, H.H.D. Macromolecular leakage beneath full cast crowns: A two-year in vitro investigation. J. prosth. Dent., v.85, n.1, p.20-5, Jan 2001.

14. COOPER, T.M. et al. Effect of venting on cast gold full crowns. J. prosth. Dent., v.26, n.6, p.621-6, Dec 1971.

15. CURTIS, S.R.; RICHARDS, M.W.; MEIERS, J.C. Early erosion of glassionomer cement at crown margins. Int. J. Prosthodont., v.6, n.6, p.553-7, 1993.

16. DEDMON, H.W. Disparity in expert opinions on size of acceptable margin openings. Oper. Dent., v.7, n.3, p.97-101, 1982.

17. DEDMON, H.W. Ability to evaluate nonvisible margins with an explorer. Oper. Dent., v.10, n.1, p.6-11, 1985.

18. DÉJOU, J.; SINDRES, V.; CAMPS, J. Influence of criteria on the results of in vitro evaluation of microleakage. Dent. Mat., v.12, n.6, p.342-49, Nov 1996.

19. DeLONG, R. ; DOUGLAS, W.H. Development of an artificial oral environment for the testing of dental restoratives: bi-axial force and movement control. $\mathbf{J}$. dent. Res., v.62, n.1, p.32-6, Jan 1983. 
20. DeWALD, J.P. The use of extracted teeth for in vitro bonding studies: A review of infection control considerations. Dent. Mat., v.13, n.2, p.74-81, Mar 1997.

21. DIMASHKIEH, M.R.; DAVIES, E.H. Measurement of the cement film thickness beneath full crown restorations. Brit. dent. J., v.137, n.1, p.281-4, Oct 1974 .

22. EAMES, W.B. et al. Techniques to improve the seating of castings. J. Amer. dent. Ass., v.96, p.432-7, Mar 1978.

23. EHRENBERG, D.S.; WEINER, S. Changes in marginal gap size of provisional resin crowns after occlusal loading and thermal cycling. J. prosth. Dent., v.84, n.2, p.139-48, Aug 2000.

24. EL-MOWAFY, O .M. et al. Retention of metal ceramic crowns cemented with resin cements: effects of preparation taper and height. J. prosth. Dent., v.76, n.5, p.524-9, Nov 1996.

25. ETTINGER, R.L. et al. An in vitro evaluation of the integrity of stainless steel crown margins cemented with different luting agents. Spec. care Dent., v.18, n.2, p. 78-83, Mar/Apr 1998. 
26. FAN, P.; NICHOLLS, J.I.; KOIS, J.C. Load fatigue of five restoration modalities in structurally compromised premolars. Int. J. Prosthodont., v.8, n.3, p.213-20, May/ Jun 1995.

27. FELTON, D. A .et al. A crown for clinically investigating microleakage. J. prosth. Dent., v.66, n.1, p.34-8, 1991.

28. FERRARI, M. et al. Marginal adaptation of crowns: a scanning electron microscopic investigation. Int. J. Periodont. Restorat. Dent., v.14, n.3, p.273-79, Jun 1994.

29. FERRARI, M.; GARCÍA-GODOY, F.; Sealing ability of new generation adhesive-restorative materials placed on vital teeth. Amer. J. Dent., v.15, n.2, p.117-28, Apr 2002.

30. FORSLIND, B. Replication techniques for dry and wet biological surfaces. Scanning Microsc., v.13, n.1, p.133-9, 1999.

31. FREEMAN, M. A et al. Leakage associated with load fatigue-induced preliminary failure of full crowns placed over three different post and core systems. J. Endod., v. 24, n.1, p.26-32, Jan 1998. 
32. FUSAYAMA, T.; IDE, K.; HOSODA, H. Relief of resistance of cement of full cast crowns. J. prosth. Dent., v.14, n.1, p.95-106, Jan / Feb 1964.

33. GALAN JÚNIOR, J. Contribuição ao estudo das principais dimensões dos dentes humanos permanentes, de leucodermas brasileiros, em ambos os sexos. Rev. bras. Odont., v.27, n.163, mar/jun. 1970.

34. GALE, M.S.; DARVELL, B.W.; CHEUNG, G.S.P. Three-dimensional reconstruction of microleakage pattern using a sequential grinding technique. J. Dent., v.22, n.6, p.370-75, 1994.

35. GATEAU, P.; SABEK, M.; DAILEY, B. Fatigue testing and microscopic evaluation of post and core restorations under artificial crowns. J. prosth. Dent., v.82, n.3, p.341-7, Sept 1999.

36. GEGAUFF, A.G.; ROSENSTIEL, S.F. Reassessment of die-spacer with dynamic loading during cementation. J. prosth. Dent., v.61, n.6, p.655-8, Jun 1989.

37. GEGAUFF, A.G. Effect of crown lenghtening and ferrule placement on static load failure of cemented cast post-cores and crowns. J. prosth. Dent., v.84, n.2, p.169-79, Aug 2000. 
38. GOLDMAN, M.; LAOSONTHORN, P.; WHITE, R.R. Microleakage- full crowns and the dental pulp. J. Endod., v.18, n.10, p.473-5, Oct 1992.

39. GORODOVSKY, S.; ZIDAN, O . Retentive strength, disintegration, and marginal quality of luting cements. J. prosth. Dent., v.68, n.2, p.269-74, Aug 1992.

40. GRAJOWER, R.; LEWINSTEIN, I.; ZELTSER, C. The effect of minimum cement thickness of zinc phosphate cement for luted non-precious crowns. J. oral Rehab., v.12, n.3, p.235-45, May 1985.

41. GROTEN, M. et al. Determination of the minimum number of marginal gap measurements required for practical in vitro testing. J. prosth. Dent., v.83, n.1, p.40-9, Jan 2000 .

42. GUNDLER, A .; LOCKOWANDT, P.; ERHARDSON, S. Crown retention and cyclic loading ( in vitro ). Scand. J. dent. Res., v.101, p.252-6, 1993.

43. HANKS, C.T. et al. Permeability of biological and synthetic molecules through dentine. J. oral Rehab., v.21, n.4, p.475-87, 1994.

44. HASEGAWA, T.; RETIEF, D.H. Quantitative microleakage of some dentinal bonding restorative systems. Dent. Mat., v.9, n.3, p.114-7, Mar 1993. 
45. HERSEK, N.E.; CANAY, S. In vivo solubility of three types of luting cement. Quintessence Int., v.27, n.3, p.211-6, 1996.

46. HOLMES, J.R. et al. Considerations in measurement of marginal fit. J. prosth. Dent., v.62, n.4, p.405-8, Oct 1989.

47. HUNG, C. et al. Effects of thermocycling and occlusal force on the margins of provisional acrylic resin crowns. J. prosth. Dent., v.69, n.6, p.573-7, Jun 1993.

48. IWAMI, Y.; YAMAMOTO, H.; EBISU, S. A new electrical method for detecting marginal leakage of in vitro resin restorations. J. Dent., v.28, n.1, p.241-7, 2000.

49. JACOBS, M.S.; WINDELER, A S An investigation of dental luting cement solubility as a function of the marginal gap. J. prosth. Dent., v.65, n.3, p.436-42, Mar 1991.

50. JANSEN, W.C. Influência da localização de aplicação do agente cimentante e da vibração no resultado final da cimentação de coroas totais metálicas . Bauru, 1983, 126p. Dissertação ( Mestrado ) - Faculdade de Odontologia de Bauru, Universidade de São Paulo. 
51. JEVNIKAR, P. et al. Micro magnetic ressonance imaging of water uptake by glass ionomer cements. Dent. Mat., v.13, n.1, p.20-3, Jan 1997

52. JOKSTAD, A ; MJÖR, I.A . Ten years`clinical evaluation of three luting cements. J. Dent., v.24, n.5, p.309-15, 1996.

53. JONES, J.G.; GRIEVE, A .R.; YOUNGSON, C.C. Marginal leakage associated with three posterior restorative materials. J. Dent., v.16, n.3, p.130-4, 1988.

54. JONES, M.D.; DYKEMA, R.W.; KEIN, A.I. Television micromeasurement of vented and non-vented cast crown marginal adaptation. Dent. Clin. N. Amer., v.15, n.3, p.663-78, Jul 1971.

55. JØRGENSEN, K.D. Factors affecting the film thickness of zinc phosphate cements. Acta Odont Scand., v.18, n.4, p.479-90, 1960.

56. JØRGENSEN, K.D.; PETERSEN, G.F. The grain size of zinc phosphate cements. Acta Odont Scand., v.21, n. , p.255-70, 1963.

57. JUDGE, R.B.; WILSON, P.R. The effects of oscillating forces upon the flow of dental cements. J. oral Rehab., v.26, n.11, p. 892-9, 1999. 
58. JUNGE, T. et al. Load fatigue of compromised teeth. A comparison of 3 luting agents. Int. J. Prosthodont., v.11, n.6, p.558-64, 1998.

59. KAUFMAN, E.G.; COELHO, D.H.; COLIN, L. Factors influencing the retention of cemented gold castings. J. prosth. Dent., v.11, n.3, p.487-502, May / June 1961.

60. KIDD, E.A .M. Microleakage: a review. J. Dent., v.4, n.5, p.199-205, Sept 1976.

61. KIDD, W.L. et al. Marginal leakage of cast gold crowns luted with zinc phosphate cement: An in vivo study. J. prosth. Dent., v.75, n.1, p.9-13, Jan 1996.

62. KNIBBS, P.J.; WALLS, G. A laboratory and clinical evaluation of three dental luting cements. J. oral Rehab., v.16, n.5, p.467-73, Sept 1989.

63. KNOBLOCH, L.A .et al...Fracture toughness of resin-based luting cements. J. prosth. Dent., v.83, n.2, p.204-9, Feb 2000.

64. LI, Z.C.; WHITE, S.N. Mechanical properties of dental luting cements. J. prosth. Dent., v.81, n.5, p.597-609, May 1999. 
65. LIBMAN, W.J.; NICHOLLS, J.I. Load fatigue of teeth restored with cast posts and cores and complete crowns. Int. J. Prosthodont., v.8, n.2, p.155-61, 1995.

66. LINDQUIST, T.; CONNOLLY, J. In vitro microleakage of luting cements and crown foundation material. J. prosth. Dent., v.85, n.3, p.292-8, Mar 2001.

67. LYONS, K.M.; RODDA, J.C.; HOOD, J. A . A . Use of a pressure chamber to compare microleakage of three luting agents. Int J. Prosthodont., v.10, n.5, p.426-33, Sept / Oct 1997.

68. MANOCCI, F.; FERRARI, M.; WATSON, T.F. Microleakage of endodontically treated teeth with fiber posts and composite cores after cyclic loading: A confocal microscopic study. J. prosth. Dent., v.85, n.3, p.284-91, Mar 2001.

69. McCABE, J.F. Resin-modified glass-ionomers. Biomaterials., v.19, n.6, p.521$7,1998$.

70. McCOMB, D. Adhesive luting cements - Classes, criteria, and usage. Comp. Continuing Educ. Dent.., v.17, n.8, p.759-73, Aug 1996. 
71. McLEAN, J.W.; VON FRAUNHOFER, J. A. The estimation of cement film thickness by an in vivo technique. Brit. dent. J., v.131, n.3, p.107-11, Aug 1971.

72. MITCHELL, C. A.; ORR, J.F. Comparison of conventional and resin-modified glass-ionomer luting cements in the retention of post-crowns by fatigue loading. J. oral Rehab., v.25, n.6, p.472-8, Jun 1998.

73. MITCHELL, C.A.; ABBARIKI, M.; ORR, J. The influence of luting cement on the probabilities of survival and modes of failure of cast full-coverage crowns. Dent. Mat., v.16, n.3, p.198-206, May 2000.

74. MITCHELL, C.A ; PINTADO, M.R.; DOUGLAS, W.H. Nondestructive, in vitro quantification of crown margins. J. prosth. Dent., v.85, n.6, p.575-84, Jun 2001.

75. MOJON, P. et al. Short-term contamination of luting cements by water and saliva. Dent. Mat., v.12, n.2, p.83-7, Mar 1996.

76. MONDELLI, J., ISHIKIRIAMA, A., GALAN JUNIOR, J. Marginal microleakage in cemented complete crowns. J. prosth. Dent., v. 40, n.5, p.632-36, Dec 1978. 
77. MOTTA, A . B. Avaliação "in vitro" do desajuste e da microinfiltração marginal em coroas metalocerâmicas cimentadas com três tipos de cimentos. Bauru, 2000. 91p. Dissertação ( Mestrado ) - Faculdade de Odontologia de Bauru, Universidade de São Paulo.

78. MOUNT, G.J. Glass-ionomers: a review of their current status. Oper. Dent., v.24, n.2, p.115-24, Apr 1999.

79. MYERS, M.L.et al. Marginal leakage of contemporary cementing agents. J. prosth. Dent., v.50, n.4, p.513-5, Oct 1983.

80. NAKABAYASHI, N.; PASHLEY, D.H. Hibridização dos tecidos dentários duros. São Paulo. Quintessence Editora Ltda, 2000.

81. NELSEN, R.J.; WOLCOTT, R.B.; PAFFENBARGER, G.C. Fluid exchange at the margins of dental restorations. J. Amer. dent. Ass., v.44, n.3, p.288-95, Mar 1952.

82. NICHOLSON, J.W. Chemistry of glass-ionomer cements: a review. Biomaterials, v.19, n.6, p.485-94, Mar 1998.

83. OLIVEIRA, J.F. et al. Influence of pressure and vibration during cementation. J. prosth. Dent., v.41, n.2, p.173-7, Feb 1979. 
84. ØILO, G. Luting cements: a review and comparison. Int. dent. J., v.41, n.2, p.81-8, Apr 1991.

85. PANDOLFI, R.F. Espaço interno entre a coroa total metálica e o dente preparado correlacionado com a resistência à remoção por tração e sua influência na cimentação. Bauru, 1983, 160p. Tese ( Livre-Docência ) Faculdade de Odontologia de Bauru, Universidade de São Paulo.

86. PASHLEY, D.H. Clinical cons iderations of microleakage. J. Endod., v.16, n.2, p.70-7, Feb 1990.

87. PASHLEY, E.L. et al. Dentin permeability: sealing the dentin in crown preparations. Oper. Dent., v.17, n.1, p.13-20, 1992.

88. PEGORARO, L.F. Prótese Fixa. São Paulo. Artes Médicas, 1998.

89. PHILLIPS, S.; BISHOP, B.M. An in vitro study of the effect of moisture on glass-ionomer cement. Quintessence Int., v.16, n.2, p.175-7, 1985.

90. PHILLIPS, R.W. et al. In vivo disintegration of luting cements. J. Amer. dent. Ass., v.114, n.4, p.489-92, Apr 1987. 
91. PILO, R. et al. Incomplete seating of cemented crowns: a literature review. J. prosth. Dent., v.59, n.4, p.429-33, Apr 1988.

92. PILO, R.; CARDASH, H.S. In vivo retrospective study of cement thickness under crowns. J. prosth. Dent., v.79, n.6, p.621-5, Jun 1998.

93. PISANESCHI, E. Infiltração marginal em coroas totais cimentadas com fosfato de zinco, ionômero de vidro e policarboxilato de zinco, estudo "in vitro" e "in vivo". Bauru, 1979. 126p. Dissertação ( Mestrado ) - Faculdade de Odontologia de Bauru, Universidade de São Paulo.

94. PlATT, J.A . Resin cements: into the $21^{\text {st }}$ century. Comp. Continuing Educ. Dent., v.20, n.12, p.1173-82, Dec 1999.

95. ROSENSTIEL, S.F.; GEGAUFF, A .G. Improving the cementation of complete cast crowns: a comparison of static and dynamic seating methods. J. Amer. dent. Ass., v.117, n.7, p.845-48, Dec 1988.

96. ROSENSTIEL, S.F.; LAND, M.F.; CRISPIN, B.J. Dental luting agents: a review of the current literature. J. prosth. Dent., v.80, n.3, p.280-301, Sept 1998. 
97. ROULET, J.F. Marginal integrity: clinical significance. J. Dent., v.22, p.9-12, 1994. Supplement 1.

98. SCHWARTZ, N.L. et al. Unserviceable crowns and fixed partial dentures: lifespan and causes for loss of serviceability. J. Amer. dent. Ass., v.81, n.6, p.1395-401, Dec 1970.

99. SELBERG, A. A full cast crown technique. J. prosth. Dent., v.7, n.1, p.102-22, Jan 1957.

100. SERVAIS, G.E.; CARTZ, L. Structure of zinc phosphate dental cement. J. dent. Res., v.50, n.3, p.613-20, May/Jun 1971.

101. SMITH, D.C. Dental cements. Curr. Opinion Dent., v.1, n.2, p.228-34, 1991.

102. TAKANISHI, A . Dental robotics: synthetic approach to mastication science. In : NAKAMURA, Y.; SESSLE, B.J. Neurobiology of mastication From molecular to systems approach. Amsterdam, Elsevier Science B.V., 1999. p.354-72.

103. TAYLOR, M.J.; LYNCH, E. Microleakage. J. Dent., v.20, n.1, p.3-10, 1992. 
104. TJAN, A .H.L. et al. The effect of thermal stress on the marginal seal of cast gold full crowns. J. Amer. dent. Ass., v.100, n.1, p.48-51, Jan 1980.

105. TJAN, A .H.L.; SARKISSIAN, R. Internal escape channel: an alternative to venting complete crowns. J prosth. dent., v.52, n.1, p.50-6, Jul 1984.

106. TJAN, A.H. et al. Marginal accuracy of complete crowns made from alternative casting alloys. J. prosth Dent., v.66, n.2, p.157-64, Aug 1991.

107. TJAN, A .H. et al. Microleakage of crowns cemented with glass ionomer cement: effects of preparation finish and conditioning with polyacrylic acid. J. prosth. Dent., v.66, n.5, p.602-6, Nov 1991.

108. TJAN, A .H.L.; DUNN, J.R.; GRANT, B.E. Marginal leakage of cast gold crowns luted with an adhesive resin cement. J. prosth. Dent., v.67, n.1, p.11-5, Jan 1992.

109. TROWBRIDGE, H.O . Model systems for determining biologic effects of microleakage. Oper. Dent., v.12, n.4, p.164-72, 1987. 
110. TUNG, F.F.; COLEMAN, A .J. Macromolecular leakage beneath full cast crowns. Part III: The diffusion of lipopolysaccharide and dextran. J. prosth. Dent., v.80, n.5, p.587-91, Nov 1998.

111. TUTIPRAWON, M. Effect of tooth surface roughness on marginal seating and retention of complete metal crowns. J. prosth. Dent., v.81, n.2, p. 142-7, Feb 1999

112. UM, C.M.; ØILO, G. The effect of early water contact on glass-ionomer cements. Quintessence Int., v.23, n.3, p.209-14, 1992.

113. VALDERHAUG, $\mathrm{J}$ et al. Assessment of the periapical and clinical status of crowned teeth over 25 years. J. Dent.., v.25, n.2, p.97-105, 1997.

114. VAN MEERBEEK, B. et al. Dual cure luting composites- part II: clinically related properties. J. oral. Rehab., v.21, n.1, p.57-66, 1994.

115. VAN NORTWICK, W.T.; GETTLEMAN, L. Effect of internal relief, vibration, and venting on the vertical seating of cemented crowns. J. prosth. Dent., v.45, n.4, p.395-9, Apr 1984. 
116. WALTON, J.N.; GARDNER, F.M.; AGAR, J.R. A survey of crown and fixed partial denture failures: length of service and reasons for replacement. J. prosth. Dent., v.56, n.4, p.416-21, Oct 1986.

117. WENDT, J.S.L.; McINNESS, P.M.; DICKINSON, G.L. The effect of thermocycling in microleakage analysis. Dent. Mat., v.8, n.3. p.181-4, May 1992.

118. WILLIAMS, J.A .; BILLINGTON, R.W.; PEARSON, G.J. The effect of maturation on in- vitro erosion of glass-ionomer and other dental cements. Brit. dent. J., v .173, n.10,.p.340-2, Dec 1992.

119. WHITE, S.N.; SORENSEN, J.A .; KANG, S.K.; Improved marginal seating of cast restorations using a silicone disclosing medium. Int. J. Prosthodont., v.4, n.4, p.323-6, 1991.

120. WHITE, S.N. et al. Microleakage of new crown and fixed partial denture luting agents. J. prosth. Dent., v.67, n.2, p.156-61, Feb 1992.

121. WHITE, S.N.; YU, Z. Film thickness of new adhesive luting agents. J. prosth. Dent ., v.67, n.6, p.782-6, Jun 1992. 
122. WHITE, S.N.; YU, Z.; KIPNIS, V. Effect of seating force on film thickness of new adhesive luting agents. J. prosth. Dent., v.68, n.3, p.476-81, Sept 1992.

123. WHITE, S.N.; KIPNIS, V. Effect of adhesive luting agents on the marginal seating of cast restorations. J. prosth. Dent., v.69, n.1, p.28-31, Jan 1993.

124. WHITE, S.N.; KIPNIS, V. The three-dimensional effects of adjustment and cementation on crown seating. Int. J. Prosthodont., v.6, n.3, p.248-54, May / Jun 1993.

125. WHITE, S.N. Adhesive cements and cementation. J. Calif. dent. Ass., v.21, n.6, p.30-7, Jun 1993.

126. WHITE, S.N.; YU, Z. Physical properties of fixed prosthodontic resin composite luting agents. Int. J. Prosthodont., v.6, n.4, p.384-9, 1993.

127. WHITE, S.N.; INGLES, S.; KIPNIS, V. Influence of marginal opening on microleakage of cemented artificial crowns. J. prosth. Dent., v.71, n.3, p.257-64, Mar 1994. 
128. WHITE, S.N. et al. In vivo microleakage of luting cements for cast crowns. J. prosth. Dent., v.71, n.4, p.333-8, Apr 1994.

129. WHITE, S.N., FURUICHI, R.; KYOMEN, S.M. Microleakage through dentin after crown cementation. J. Endod., v.21, n.1, p.9-12, Jan 1995.

130. WHITE, S.N. et al. In vivo marginal adaptation of cast crowns luted with different cements. J. prosth. Dent., v.74, n.1, p.25-32, Jul 1995.

131. WHITE, S.N. On the cutting edge: marginal integrity. J. Calif. Dent. Ass., v.23, n.12, p.72-6, Dec 1995.

132. WILSON, A . D. Developments in glass-ionomer cements. Int. J. Prosthodont., v.2, n.5, p.438-46, 1989.

133. WILSON, P.R. Crown behaviour during cementation. J. Dent., v.20, n.3, p.156-62, Jun 1992.

134. WISKOTT, H.W. A .; NICHOLLS, J.I.; BELSER, U.C. Stress fatigue: basic principles and prosthodontic implications. Int. J. Prosthodont., v.8, n.2, p. $105-16,1995$. 
135. WISKOTT, H.W.A ; NICHOLLS, J.I.; BELSER, U.C. The relationship between abutment taper and resistance of cemented crowns to dynamic loading. Int. J. Prosthodont., v.9, n.2, p.117-30, 1996.

136. WISKOTT, H.W.A .; NICHOLLS, J.I.; BELSER, U.C. The effect of tooth preparation height and diameter on the resistance of complete crowns to fatigue loading. Int. J. Prosthodont., v.10, n.3, p.207-15, 1997.

137. WISKOTT, H.W.A ; BELSER, U.C.; SCHERRER, S.S. The effect of film thickness and surface texture on the resistance of cemented extracoronal restorations to lateral fatigue loading. Int. J. Prosthodont., v.12, n.3, p.255-62, 1999.

138. YAMASHITA, J. et al. Surface strain on crown and luting cement fractures. Int. J. Prosthodont., v.10, n.4, p.332-39, 1997.

139. YAMASHITA, J. et al. Deformation of restoration and fracture of luting cement film. J. Dent., v.26, n.5-6, p.459-66, 1998.

140. YAMASHITA, J. et al. Fatigue behavior of zinc-phosphate cement layer. Int. J. Prosthodont., v.13, n.4, p.321-26, 2000. 
141. YOSHIDA, Y.; TANAGAWA, M.; ATSUTA, M. In- vitro solubility of three types of resin and conventional luting cements. J. oral Rehab., v.25, n.4, p.285-91, Apr 1998. 
ABSTRACT 


\section{ABSTRACT}

The purpose of this study was to verify "in vitro" measures and possible correlations between seating discrepancy, marginal opening and microleakage pattern under total metallic crowns cemented with three types of luting agents: phosphate, glass-ionomer and resin dual cement. Thrirty extracted human premolars teeth were prepared for total metalloceramic crowns and castings obtained with a $\mathrm{Ni}$ $\mathrm{Cr}$ alloy. Samples were ramdomly assigned for three groups in according to each luting agent: zinc phosphate (S.S.White), resin-modified glass-ionomer (Vitremer$3 \mathrm{M})$ or a dual resin cement (Enforce-Dentsply). Cementation was done under a $49 \mathrm{~N}$ load for 10 minutes and water stored for $24 \mathrm{hs}$. Vertical discrepancy was registered before and after cementation in an optical microscopy with the accuracy of $0,001 \mathrm{~mm})$. Half of the specimens within each group was submitted to a cyclic loading test $(50000$ cycles, $2,5 \mathrm{~Hz})$. Crowns were longitudinally seccionated in a bucco-lingual plane at the tooth-cement-crown interface and dye solution (rodhamine B) was apllied to tooth-cement-interface for 15 seconds The linear stain penetration along tooth-cement was quantified. under a light microscope (80X magnification) and then samples were prepared for scanning electronic microscope in order to quantify marginal opening and the quality of interface. The results for seating discrepancy were higher for zinc phosphate, followed by glass-ionomer and resin cement, with no statistical difference. Statistically significant differences were found between seating discrepancy and marginal opening for the three cements. Microleakage results were higher for zinc phosphate, followed by glass-ionomer and resin cement, with statiscally significant differences. Fatigue loading rinsed marginal 
leakage for zinc pohsphate, with statiscally significant difference in respect to glassionomer and resin cement. Scanning electron microscope analysis showed better marginal quality at the tooth-cement-restoration interface for resinous cement, followed by glass-ionomer and zinc phosphate cement. 


\section{FACULDADE DE ODONTOLOGIA DE BAURU \\ COMTE DE ETTCA EM PESQUISA}

Bauru, 1 de jurho de 2001

Inmo Sr.

Prof. Dr. Luiz Fernando Pegoraro

FOB USP

Senher Professor

O projeto de pesquisa denominado "Influênoia da apliengão de cielagem com carğa dinâmicas na microinfiltraçä́ marginal em coroas metaloseràmicas eimentadas com trề tipos de clmentoe", de autoria do C.D. Paulo Henrique Orlato Rlosseti e que serh desenvolvido sob sua orientaça, foi recebido por este Comits o encaminhado ao relator para avaliagra quanto aos selus arpectos fticos.

O parecer do relator, aprovando o prejeto, foi aceito pelo Comits de tica em Pesquisa desta Faculdade nn reuniao de 31 de maio de 2001.

Atenciogamente

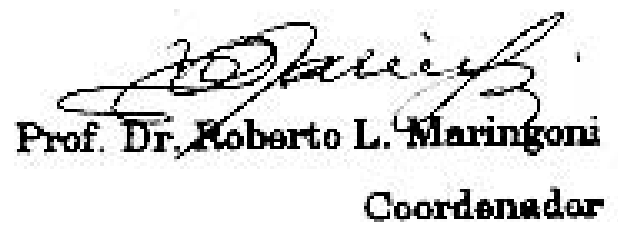

